\title{
Osmanlı Taşrasında Saray Bürokrasisi: Şehzade Selim'in Kazayâ Defteri
}

\author{
Feridun M. Emecen*
}

Palace Bureaucracy in Ottoman Provinces: Prince Selim's Kazayâ Register

Abstract $\square$ There is a dearth of documentation regarding administrative practices of Ottoman princes in provinces where they were sent as governors until the end of the sixteenth century so that they could gain practical experience. Previously, I had located in Prime Ministry's Archives in Istanbul certain registers (defter) produced in princely courts and made some remarks about their format and characteristics. Belonging to a princely court as well, the register under scrutiny here consists of petitions regarding appointments, promotions and other financial dealings as well as answers to those petitions. It covers Prince Selim's (future Selim II) first years as governor of Manisa (1544-1546). After the manner they were presented to the sul$\tan ($ kazıyye), I named such registers as kazayâ defteri. Issues included in this register demonstrate us problems that an Ottoman prince had to deal with during his governorship and give us an idea about how princely bureaucracy functioned.

Keywords: Kazayâ register, Prince Selim, Princely court, Provincial bureaucracy, Manisa Court

Osmanlı tarih araştırmalarında eksikliği hissedilen çalışma alanlarından birini taşra bürokrasisi teşkil etmektedir. Taşra teşkilatının ana yapısını anlamakta, hinterlandındaki meseleleri kavramakta ve onun merkezle irtibatını belirlemekte ciddi bir bilgi açığı olmasının en büyük sebeplerinden birini taşradaki idari bürokrasinin ürettiği evrakın mevcut bulunmayışı oluşturur. Nispeten düzenli bir külliyat halinde zamanımıza ulaşan mahkeme sicilleri dışında taşradaki yöneticilerin yani sancakbeyi ve beylerbeyi divanlarında alınan kararlarla alakalı

* İstanbul 29 Mayıs Üniversitesi 
mutlaka mevcut olması gereken evrak veya defterlerin âkıbeti hususu zihinleri meşgul eden önemli bir mesele olarak karşımızda durmaktadır. Bazı paşaların özel mektuplarıyla resmî yazışmalarına, XIX. yüzyıla ait bir kısım evraka dair birtakım bilgiler mevcut olmakla birlikte, özellikle klasik çağa, yani XV. ve XVI. asra ait taşra belgelerine hemen hemen hiç rastlanmamış olması ${ }^{1}$, bunların tahrib edilmiş olabileceği, idarecilerin şahsi evrak şeklinde telakki edip yanlarında götürmüş bulunabilecekleri gibi naif ve temelsiz cevaplarla karşılanmaktan öte daha makul ve kabul edilebilir bir çözümü hak etmektedir. Bu tür taşra belgelerinin eksikliğinin imparatorluk taşrasına merkezde üretilmiş evrak ve defter serileriyle tek taraflı bir bakışa yol açmış olması, hiç şüphe yok ki durumu fark edenler için konunun önemini daha da artırmaktadır.

Şu halde eğer mevcutsa ve bugüne ulaşmışsa bu tür belgeler acaba nerede bulunabilir? Bu sualin cevabı için akla öncelikle Şer'iyye Sicilleri gelir. Gerçekten de bu defterler taşraya gönderilmiş talimat, ferman v.b. kayıtları ihtiva etmektedirler. Fakat muhtemelen aynı zamanda beylerbeyi divanında kadının da katılmış olduğu meselelerle alakalı bazı kayıtların şer'iyye sicil defterlerinde yer alması mümkündür. Bu kayıtlar söz konusu defterlerin tutuluş mantı̆̆ı itibarıyla dikkatlerden kaçmış olmalıdır. Mesela İstanbul sicillerinde yine örneklerine pek rastlanmayan veziriazamın ikindi divanına dair kayıtların mevcut olduğu anlaşılmışıı ${ }^{2}$. Benzeri durumun taşradaki eyaletler için de geçerli olmaması için bir sebep yoktur. Bunun dışında taşra evrakının aranması gereken bir diğer yer, Başbakanlık Osmanlı Arşivi'dir'. Bir kısım müteferrik evrakın burada çıkmasının sebebi, daha ziyade muamele ve bürokratik işlemler dolayısıyladır; taşradan merkeze yollanan

1 Burada kastedilen, defter türünün mevcud bulunmaması keyfiyetidir. Yoksa mesela bazı Budin beylerbeyilerinin Habsburglar'a veya onlara bağlı beylere gönderdikleri, çoğu Budapeşte ve Viyana arşivlerinde bulunan mektublardan haberdarız (A Budai Basák Magyar Nyelvü Levelezése 1553-1589, ed. S. Takáts- F. Eckhart-Gy.Szekfü, Budapest 1915; The Hungarian Letters of Ali Pasha of Buda 1604-1616, ed. G. Bayerle, Budapest 1991). Keza Dubrovnik arşivlerinde de bazı sancakbeyi ve Bosna beylerbeylilerinin pek çok özel veya resmi mektubu mevcuttur (F. M. Emecen-İ. Bostan, "Dubrovnik Arşivi'ndeki Osmanlı Belgeleri ile İlgili Rapor”, Belleten, LXII/235, 1999, s. 917-920). Ancak bunlar diplomatik yazışmalar tarzında olup bürokratik bir iç çalışmayı yansıtmaz.

2 İstanbul Bab Mahkemesi Sicilleri, nr. 3’teki örnekler.

3 Eyalet divanlarında ruzname, muhasebe defterleri gibi çeşitli defterlerin tutulduğu bilinmektedir, fakat bunlara ait çok az örnek mevcuttur: M. İpşirli, "Beylerbeyi”, DİA, VI, s. 73; keza sancakbeyi divanındaki muamelat ile merkezdeki evrak arasındaki bağlar için bk. Z. Mete, "Osmanlı Taşrasında Bürokratik Muamelat: Sancakbeyi Belge ve Defterleri”, Osmanlı Araştırmaları, XIX (1999), s. 181-221. 
defterler, bu kategoriye dahil edilebilir. Fakat mahalli ölçekli kayıtların, herhangi bir muamele için değil de doğrudan taşradan merkeze "arşivlenmek üzere" intikal etmiş bulunduğu da düşünülebilir. Bu sonuncu fikri doğrulayan en güzel örnek bundan uzunca bir zaman önce tarafımdan ilk defa tespit edilip adlandırılmış bulunan XVI. yüzyıla ait bir seri defterin varlığıyla tebellür eder. Bundan dolayı Başbakanlık Osmanlı Arşivi'ndeki belge ve defterlerin tamamıyla merkezdeki bürokratik faaliyetleri yansıttığını düşünmek yanıltıcı olacaktır. Dikkatli gözlerle yapılan incelemelerin daha farklı taşra belgelerinin tesbitini sağlayacağına şüphe yoktur.

Taşra evrakını yansıtan defterlere örnek olarak XVI. yüzyılın sonlarına kadar değişik sancaklarda görev yapan şehzadelerin divanında ve saraylarında tutulmuş bulunanlarına dair tarafımdan "Şehzade Divan Defterleri" adıyla hem tanımlayıcı hem de muhtevalarını tanıtıcı yazılar kaleme alınmışı ${ }^{4}$. Bu yazılardaki tesbitler tekrar edilmeksizin burada kısaca bu defterlerin türleri hakkında bilgi verildikten sonra, esas olarak bunlar içerisinde çok farklı bir yere sahip olan ve benzerine hemen hemen hiç rastlanmayan bir defteri mercek altına alıp bunun idari yönelim, tatbikat ve gündelik hayat açısından hakkında hiçbir şey bilinmeyen "Şehzade Sarayı" kavramı üzerindeki belirsizlik örtüsünü nasıl araladığı, hangi hususlara açıklık getirdiği üzerinde durulacaktır. Bunun sadece merkezdeki sarayın küçük bir modeli olan şehzade sarayı temelli "öğretici bilgiler" ortaya koymak açısından değil, aynı zamanda şehzadenin idari yetki alanı dahilinde sarayla bütünleşen çevre faktörleri, taşra kaynaklı etkiler, nepotizmin mahiyeti vb. gibi birtakım problemler bakımından da taşra idaresiyle merkez arasındaki bağa farklı bir pencere açacağı düşünülebilir.

Konuya girmeden önce kısaca şehzade divanına ait defterler hakkında bazı bilgiler vermek elzem görünür: Tespit edilebildiği kadarıyla taşradan merkeze intikal etmiş olan şehzade divanına ait defterlerin en eskisi, Fatih Sultan Mehmed'in oğlu Şehzade Bayezid (II)'in Amasya'da bulunduğu sırada 24 Cemaziyelahır- 4 Şevval 879 (5 Kasım 1474- 11 Şubat 1475) tutulmuş kayıt defteridir. Bu defterde sadece gündelik olarak divana kaç tane şikâyet mektubu (vakıflarla ilgili olanlar dahil) geldiği, kaç berat, muafiyetname, yol mektubu, şefkatnâme yazıldı ̆̆ı, ne gibi görevler tevcih edildiği belirtilmekte, fakat bunların muhtevaları verilmemektedir ${ }^{5}$.

4 Bunlar için bk. F. M. Emecen, "Taşra Bürokrasisinin Kaynakları: Şehzâde Divan Defterleri”, Tarih Boyunca Türk Taribinin Kaynaklarn Semineri, Bildiriler, İstanbul 1997, s. 91-100; keza a.mlf, Osmanlı Klasik Çağında Hanedan Devlet ve Toplum, İstanbul 2011, s. 83-93.

5 Topkapı Sarayı Müzesi Arşivi, nr. D. 9873. 
Bu defterin tertip tarzı burada ele alınacak olan kazaya defteriyle nisbî ölçüde benzerlik arzeder. Söz konusu defter parçası diplomatik açıdan muayyenlik kazanmamış bir bürokratik tarzı yansıtan bir "prototip" hususiyeti arzeder. Defter günlük olarak tutulmuş, gün başlıklarının altında yukarıda bahsedildiği üzere ilgili kısa kayıtlara yer verilmiştir. Mesela Receb ayıyla ilgili kayıt kısmının ilk iki günü şu şekildedir:

\section{“[s.1] Gurre-i mâh-1 Recebü'l-mücerreb li-sene tis'a ve seb'in ve semân-mie, rûz-1} cum'a, be-makam-1 Amasya

Mektûb-1 şikâyetciyân: 2

Şefkatnâme: 1

Rûz-1 şenbih 2

Mektûb-1 şikâyetciyân: 1

Mu'âfiyetnâme: 1

Mektûb-1 şikâyetciyân : 8”

Rahatlıkla anlaşılacağı üzere burada şehzadenin divanında bürokratik gerekçelerle ve pratik gayelerle hazırlanmış bir küçük envanter söz konusudur, bu açılardan da ekte yayımladığımız "kazayâ defteri” ile önemli ölçüde farklılık arzeder. Belki de bu prototip defterin daha sonraları zamanla geliştirilmiş halini bu yazıya konu olan kazayâ defteri temsil etmektedir.

Bunun dışında bir başka tür defter, şehzadelerin sancağa çıkışları sırasında tutulan ve maiyetlerindeki personeli, onlara verilen in'am ve caizeleri ihtiva etmektedir ${ }^{6}$. Ancak bunlar taşrada üretilmiş bir vasıf taşımamaktadır. Arşiv çalışmaları sırasında tarafımdan tesbit edilen ve gerçek anlamda taşrada tutulmuş, şehzade divanına, sarayına ait olup merkezdeki bürokratik muamelatla ilgisi olmayan türler ise üç ana kategoride tasnif edilebilir:

Bunlardan ilki, doğrudan şehzade divanında alınan kararların yer aldığı merkezdeki ahkâm defterlerine benzeyen türdür. Bunlar klasik (genişs şekilli) Mühimme defterleri formunda değil daha çok (dar ve uzun şekilli) maliye ahkâm defterleri tarzındadır, fakat muhteva itibarıyla divandan çıkan her türlü mali, siyasi, sosyal muhtevalı konuları içine alır, şikâyetlere ve yapılan çeşitli başvurulara karşılık divanda çıkan kararları muhtevidir. İkinci tür olanlar maaşlarla

6 İ. H. Uzunçarşılı, "Sancağa Çıkarılan Osmanlı Şehzadeleri”, Belleten, XXXIX/156 (1975), s. 659-696; Ç. Uluçay, "Kanuni Sultan Süleyman ve Ailesi ile İlgili Bazı Notlar ve Vesikalar”, Kanuni Armă̆anı, Ankara 1970, s. 237-241 
ilgili hizmetli listelerini muhtevi mevâcib kayıtlarını mündemiçdir. Üçüncüsü ise harcama kalemleriyle ilgili mutfak masraflarının muhasebesinin tutulduğu defterlerdir ${ }^{7}$. Burada incelenecek kazayâ defteri ise bu üç kategorinin tamamen dışında, benzerine pek tesadüf edilmeyen çok farklı bir karakterde tutulmuş olup muhteva yönünden de diğerleriyle alakasız bir türü yansıtır.

Başbakanlık Osmanlı Arşivi, D.BŞM, nr. 23’te mukayyet bu defter Şehzade Selim'in Konya'dan Manisa’ya gelişi ile birlikte Manisa Sarayı'nda tutulmaya başlanmıştır. Başlangıç tarihi 951 Safer ayıdır (Nisan 1544). Ancak asıl gündelik kayıtlar ileride bahsedileceği gibi 12 Cemaziyelahır 951/ 31 Ağustos 1544 başlığı altında yer almaktadır. Bu başlık öncelikle divana mahalli olarak yapılan başvuruları hatıra getiriyorsa da aslında burada daha çok saray çevresindeki hizmetlilerin ve doğrudan şehzadeyi ilgilendiren işlerle ilgili konuların esası teşkil ettiği görülür. Yani defter tamamen şehzade sarayının iç işleri ve idaresine, personeline ait özel bir nitelik taşır. Bu haliyle de bir ölçüde merkezdeki doğrudan padişahı ilgilendiren iç hazine kayıtlarını veya belirli bir tarihe kadar farklı şekilde tutulan küçük ruznamçe, in'am vb. defterleri andırır ${ }^{8}$, fakat tevcih ve ulufe tayini ve terakkilerinin bulunması dolayısıyla yine onlardan esaslı şekilde farklılık gösterir. Bir ölçüde merkezdeki "ruus defterleri” tarzında düzenlenmiştir denilebilir. Hatta onların ilk örneklerinden biri olarak da kabul edilebilir. Zira merkezde mevcut ruus defteri tarzının ortaya çıkışı, bu defterin tarihiyle hayli yakınlık gösterir ${ }^{9}$. Aslında merkezle doğrudan herhangi bir ilişkisi olmayan şehzade kapısını alakadar eden bir özelliğe sahiptir; burada merkezle irtibatlı olan timar teklifleri ve tevcihleri; keza şehzade divanından çıkan mahalli/bölgesel konulara, merkezle irtibata ait hükümler yer almaz. Kısaca defter çok değişik bir tarzda tutulmuştur, şehzadeye adeta veziriazamı mahiyetinde olan lalası tarafından çeşitli konularla ilgili sunulan küçük arzlar, "kazıyye" şeklinde keşideli başlık altında belirtilmiş; bunun üstünde de bizzat şehzadenin kararı "buyruldusu" farklı bir kaligrafiyle kaydedilmiştir. Bu

7 Bunlar için bk. F. M. Emecen, "Şehzade Divan Defterleri”, s. 87 vd. Bu defterler üzerinde meslektaşlarım Z. Mete ve A. Bilgin ile beraber bir yayın projesi başlatmış ve tesbit ettiğimiz bu tip defterlerin tamamını yayına hazırlamış bulunmaktayız. Mutfak kayıtları ile ilgili defter ise daha önce tarafımdan yayımlanmıştı: "Şehzadenin Mutfağı: III. Mehmed'in Şehzadelik Döneminde Manisa Sarayına Ait Bir Mutfak Masraf Defteri”, Tarihin İcinde Manisa, Manisa 2007, s. 73-114.

8 Mesela merkezdeki inam defteri (hazine ruznamçe kayıtları) ve iç hazine defterine (TSMA, nr. D. 34) benzer kayıtlar da vardır.

9 Merkezdeki divan defterlerinin tarihi gelişimi için bk. F. M. Emecen, "Osmanlı Divanının Ana Defter Serileri: Ahkâm-1 Mîrî, Ahkâm-1 Kuyûd-1 Mühimme ve Ahkâm-1 Şikâyet”, Türkiye Araştırmaları Literatür Dergisi, III/5, İstanbul 2005, s. 107-139. 
defterin divanda katibler tarafından yazılmış olduğuna dair karineler de bulunur. Muhtemelen söz konusu defter, küçük tezkirelerin ve bunların üzerinde yer alan buyrulduların sonradan bir araya getirilmiş ve defter formuna sokulmuş toplu sureti olmalıdır. Meselelerin ve şehzadenin oluruna sunulan konuların hemen çoğunun "kazıyye" başlığıyla verilmekte olması ayrıca dikkat çeker. Birkaç yerde kazıyye yerine keşide başlık, "tafsîl”" tarzındadır. Bu sebeple muhteva ve şekil açısından defter, arz tezkireleri defteri değil "kazıyye/kazayâ defteri” adıyla tanımlanmayı daha çok hak eder.

Öte yandan defterdeki "kazıyye, mevâcib, in'am” veya ilgili görev gruplarını ifade eden "cemaat" gibi keşideli başlıkların üzerinde bazı işaretlere de yer verilmiş olduğu dikkati çeker. Bu tür ibareler bürokratik muamele açısından ilgili kaydın özelliğini yansıtmaktadır. Daha çok da kaydı tutan kâtibin bürokratik işlemini alakadar eden işaretler niteliğini taşır. Bunlar stilize şekilde keşide başlık üzerine yatay olarak düşülmüş "ta’yîn", "nakluhu", "baki" ve "sahh" kayıtlarıdır. Tayin kayıtlarının çoğu maaş artıımı, terakki gibi kararların üzerinde yer alır. "Nakluhu”" tabiri ise genellikle bir görevden bir başka göreve geçiş ile alakalı olmalıdır. Ayrıca birkaç kayıtta rastlanan [ki] şeklindeki kısaltma, "baki" kelimesine aittir ve muhtemelen görevde mukarrer tutulanlar için düşülen notu göstermektedir. Ancak tayin ve nakluhu ifadelerinin her zaman yukarıda belirtilen kategorik durumları belirtmediği, bazen memuriyet değişiklikleri ve terakkiler için karışık şekilde birbirinin yerine kullanılabildiği de tesbit edilebilmektedir. Daha çok hazineyi ilgilendiren defterdeki bu tür bürokratik muamelatın, kâtibin daha sonra bunları işleme koyma ameliyesini kolaylaştırma ve kayıtları birbirinden kolayca ayırt etme pratiğinden kaynaklandığı düşünülebilir.

Defteri hazırlayan kalemiye erbabına gelince öncelikle "paşa” unvanıyla da anılan lalanın ve defterdarın sunduğu tezkirelerin metne esas teşkil ettiği, hatta zaman zaman tezkire kayıtlarının üzerine bunların notlarının bulunduğu görülmektedir. Defterdarın daha çok mali konular ve alım satım meseleleriyle ilgili olarak devreye girdiğine şüphe yoktur. Defterdeki bürokratik işlemleri yapanlarla ilgili olarak divan ruznamecisi olan kâtibin (İbrahim Bey) memleketi olan Edirne'ye gitmek için izin istediği bir arzda, ruznamecinin yerine bu hizmeti "Paşa hazretleri cânibinden ruznâme yazan Fazlullab" ve "bendenüz cânibinden ruznâme yazan İsmail' in yürüteceği belirtildiğine göre, burada şehzadenin oluruna sunulan arzları kendisini "bendeniz" diye tanıtan defterdarın hazırladığı rahatlıkla anlaşılır (s. 41) ${ }^{10}$. Nişancının

10 Burada metin içinde verdiğimiz sayfa numaraları ekte yayımladığımız defterin orijinal sayfalarına işaret etmektedir. 
adının Mehmed Bey olduğu ilerideki bir bayram dolayısıyla verilen in’am kayıtlarından ortaya çıkar. Bu kayıtlardan şehzadenin sarayındaki üst düzey divan ve hazine katiblerinin adları sıralanmıştır. Buna göre nişancı Mehmed Bey'den sonra kapıcılar kethudası Mehmed Bey, divan katibleri Mahmud, Mehmed, İsmail beyler, divitdar ve hükkâm kâtibi olarak Hüsrev Bey, ruznâmeci İbrahim Çelebi, mukataacı Kurd Çelebi, tezkireci Süleyman Çelebi, muhasebeci Hüseyin Çelebi, Paşa kâtibi Fazlullah, defterdar kâtibi İsmail, mukataacı yardımcısı Ali, vezzân Muslihiddin ve çadır mehterleri başı Hamza’nın adları sıralanmıştır. Bunlar içinde muhasebeci kadrosunun yeni ihdas edildiğine dair kayıt ilginçtir. Burada muhasebeciliğin ruznameci İbrahim Çelebi'nin uhdesinde olduğu ama iş yoğunluğu yüzünden ayrı bir muhasebeci kadrosunun oluşturularak bunun sipahi oğlanları kâtibi Hüseyin Çelebi'ye verildiği belirtilmiştir (s. 16). Ayrıca defterde bazı ruus defterlerinde rastlandığı gibi divana arz tezkireleri sundukları başlık altında belirtilenler "Paşa" unvanıyla kaydedilen lala ve defterdardır (bk. s. 38 ve 39). Sunulan arzların ve tezkirelerin çoğunda buyruldu kayıtları mevcut olmakla birlikte bazılarında herhangi bir kayıt düşülmemiştir.

Defterin şekli ve niteliği hususundaki bu bilgilerden sonra tarihî zemine dönecek olursak, defterin Manisa'da tutulmaya başlanma tarihi, Şehzade Mehmed'in vefatı üzerine ağabeyisinin yerine Manisa'ya nakledilen Şehzade Selim'in Bursa yoluyla idarecilik yapacağı bu şehre geldiği 17 Cemaziyelevvel 951/6 Ağustos 1544 'den yaklaşık bir ay sonrasına rastlar. Fakat defterde 951 Safer ayı ile ilgili tezkirelerin değerlendirildiğine ve bunların da yol ile ilgili meseleler olduğuna bakılırsa, Konya’dan babası ve annesiyle buluştuğu ve bir süre kaldığı Bursa ile oradan Manisa’ya gelişi sırasındaki kayıtların da mevcut olduğu görülebilirr ${ }^{11}$. Defter eksik olduğu için bu döneme ait parça kopmuş olmalıdır. Başlıksız olarak "tafsil oldur ki” diye başlayan defterin ilk kaydında, Konya'dan Manisa'ya kadar hizmet eden 17 saraç ve bunların yardımcıları ile nalbantların görev yükseltmeleri ile ilgili arzlarına yer verilmiştir. İlerleyen sayfalarda da Konya-Bursa-Manisa yolculuğu ile ilgili gerek binek hayvanları ve bunları idare eden seyisler, gerekse çadır ve nakil arabaları ile alakalı bir kısmı görev yükseltme, bir kısmı ulufe artırma veya yeni arabacı, seyis istihdam etme gibi konulara sıklıkla rastlanmaktadır. 951 Safer ayını takip eden üç ay için herhangi bir kayda rastlanmamış olması, defterdeki eksiklik sebebiyle olabilir. Defterde aylara göre ana başlık atılmaksızın kayıtlar birbiri peşi sıra verilirken "buyruldu" ibareleri yanına günün tarihi belirtilmiştir. Başlangıç

11 Selim Bursa’da bir süre babası ve annesiyle birlikte kaldı ve vakit geçirdi; Vusulî, onun babasıyla sık sık gezintiye çıktığını, avlara katıldığını yazar (Selimnâme, nşr. N. Öztürk, Türk Dünyası Araştırmaları, sy. 50, 1987, s. 33). Bu hasret giderme, muhtemelen Mehmed'in vefatının verdiği üzüntüyü ailece paylaşmaktan kaynaklansa gerektir. 
tarihli olarak yalnızca iki başlık mevcuttur. Bunlardan ilki "Defter-i tezkire-i arz ki der-mahrûse-i Manisa, vâki şud el-vâki fî 12 Cemaziyelahır sene 951" (bk. s. 4) ve bir sene sonrasına ait ikincisi "Defter-i tezkire-i arz el-vâki fì gurre-i Ca sene 952" (s. 2) şeklindedir. Böylece defterin Manisa Sarayı'nda 12 Cemaziyelahır 951/ 31 Ağustos 1544 tarihinden itibaren nispeten düzenli olarak tutulmaya başlandığ 1 ve 953 yılı Muharremine (Mart 1546), yani Hürrem Sultan'ın Manisa’ya ziyaret için yola çıktığı ama Manisa’ya henüz ulaşmadığı tarihe kadar geldiği ortaya çıkar ${ }^{12}$. Sonuncu kayıtlarda "sultan hazretleri” diye anılan Hürrem Sultan' ın Manisa’ya doğru gelmekte olduğu, onu karşılamak üzere giden gruptaki mutfak hizmetlileriyle mehterlerden bazılarına at kifayet etmediği ve kiralanması gerektiği belirtilmiştir (s. 48). Defterin bundan sonraki kısımları hakkında şimdilik herhangi bir kayda rastlanmamıştır. Bundan dolayı elimizdeki defter Ağustos 1544-Mart 1546 tarihleri arasındaki, bir sene altı aylık kayıtları muhtevidir.

Defterin tutulmasında asıl pay sahibi olan ve tezkireleri alıp şehzadeye ileten, bazen doğrudan tekliflerde bulunan şahıs laladır. Defterdeki bazı kayıtlarda kendisi "Paşa" unvanıyla anılırsa da adı herhangi bir yerde geçmez. Fakat bu dönemde şehzadenin lalasının Konya'ya giderken onun yanına verilen Cafer Bey olduğu tesbit edilmektedir ${ }^{13}$. Lala Cafer Bey'in yeniçeri ağalığından çıkan, daha sonra ŞamHalep taraflarında beylerbeyilikte bulunan Lala Cafer Paşa olduğu tahmin edilir. Kendisi muhtemelen 1550'de Lala Hüseyin Bey'in lala oluşuna kadar bu görevde kalmıştır. Şehzade Selim ile birlikte Manisa'ya gelenlerin sayıları hakkında bilgi yoktur; ancak başka örneklerden hareketler onun Konyadaki adamlarının çoğunu Manisa’ya getirdiği anlaşılmaktadır. Taşıma işiyle ilgili defterde yer alan kayıtlar, eşyaların ve haremin 17 arabayla taşındığını, nakil işinde Anadolu beylerbeyi İbrahim Paşa’nın hizmetkârlarının önemli ölçüde yardımda bulunduklarını gösterir. Nitekim 50'si deveci, 33'ü de bunların yardımcısı olduğu anlaşılan 130 kişiye şehzade kapısından çeşitli inamlar ve hediyeler verilmiştir. Konya'dan getirilen at sayısının 415 olması ve bunların 30 seyisle idare edilmekte bulunması dikkat çekicidir. Ayrıca 157 katır da taşıma işinde kullanılmıştır. Özellikle yolculuk için Karaman bölgesinden 230 baş devenin satın alındığı; Manisa Sarayı'ndaki ahırda ise toplam deve sayısının 60 katara, yani 500'e yakın devenin mevcut olduğu;

12 Ancak defterde 951 Cemaziyelahırından itibaren her ay için kayıtlar bulunurken, 952 yılına ait Cemaziyelahır ayı ile alakalı herhangi bir kayda rastlanmamaktadır. Burada bir kopma söz konusu olabilir: bk. Orijinal metin, s. 38-39.

13 F. Emecen-İ. Şahin, “Osmanlı Taşra Teşkilatının Kaynaklarından 957-958 (1550-1551) Tarihli Sancak Tevcih Defteri”, Belgeler, XIX/23 (1998), s. 59 
bunlardan sakat ve hastalıklı olanların ise satılmasına karar verildiği kaydedilmiştir (s.6, 12-13).

Şehzade Selim’in Ağustos ayında Manisa'nın çok sıcak olduğu bir mevsimde şehre gelmesi ve yaylakların da hazır olmamasından dolayı sahil kesimine inerek orada kaldığına dair Vusulînnin verdiği bilgiyi doğrulayan bir kayıt defterde yer alır. Burada Tarhaniyat (Menemen) taraflarındaki bir saraydan söz edilmektedir ki bu sarayın, Bizans döneminden kalma olduğu tahmin edilebiliri ${ }^{14}$. Ayrıca saray için kar talebinde bulunulması da sıcakların etkisinden dolayıdır (s. 8). Onu takip eden kış mevsiminin çok sert geçmesi, Şehzade Selim’i rahatsız etmiş olmalıdır ${ }^{15}$. Manisa’ya geldiğinde de Şehzade Mehmed'in lalası Halil Paşa’nın onu karşıladığı ve buna karşılık kendisine bir seraser hil'at verildiği, yine Sakız'dan şehzadeyi tebrik için bir elçinin Manisàya ulaştığı, ona da hediye takdim edildiği dikkati çeker (s.8).

Şehzade Selim'in sarayı ile ilgili olarak defterdeki kayıtlar birkaç kategoride değerlendirilebilir. İlk olarak şehzadenin ailesi ve haremine dair hizmetkâr tahsisi, günlük ulufelerin artırılması gibi çeşitli vesilelerle yer alan kayıtlar, bazı yeni bilgilere ulaşmayı sağlar. Öncelikle Vusulî̀nin belirttiği gibi Selim, Konya’dan Manisa’ya geldiğinde iki kızı henüz yeni doğmuştu. İlk çocuğu İsmihan Sultan, ikincisi ise Gevherhan Sultan idi. Defterdeki Haremi ile ilgili ilk kayıtlarda iki çocuğunun validesine yapılan tahsise rastlanır (s. 9). Daha sonra 10 Receb 951/ 27 Ekim 1544'de muhtemelen üçüncü kızı Şah Sultan'ın doğumu ile defterde "şehzade vâlidesi" olarak belirtilen kadınlarının sayısı üç olarak verildiği gibi, günlük yevmiyelere

14 Tarhaniyat, Bizans döneminde aristokrat bir ailenin (Tarchaneiotai) bulunduğu yerdir. Burada herhangi bir saraydan bahsedilmemekle birlikte, onlara ait olup daha sonra da Saruhanoğulları tarafından kullanılmış bir yazlık ikametgahın mevcud olduğu düşünülebilir (Tarhaniyat hakkında bk. İ. Beldiceanu Steinherr-T.Ganchou, "Tarhaniyat/ Menemen, de Byzance a l'Empire ottoman", Turcica, sy. 38 (2006), s. 47-12). Burasının Manisàya 20-25 km. kadar uzaklıkta bugün halk arasında Yoğurtçu Kale diye anılan ve bazı kayıtlarda Sosandıra Manastırı diye de geçen yer ile ilgisi tahkike değer. Şehzadelerin zaman zaman Susandıraz adlı yaylağa (Sultan yaylası) gittikleri bilinmektedir. Ancak Susandıraz yaylasının burası ile irtibatı hakkında ciddi şüpheler vardır (Kale hakkında bk. Emine Tok, Manisa Yakınlarında Bir Ortaçă̆ Kalesi: Yoğurtçu Kale, Manisa 2012, s. 159-181). Evliya Çelebi'nin beyanları yanında Timurtaşoğlu Ali Bey Cami ve imaretinin vakıf gelirleri arasında Susendıraz yaylasının mukataa geliri de bulunmakta ve bu vakıfların Gürle civarında olduğu istidlal edilmektedir (F. Emecen, Manisa Kazası, s. 100).

15 "Manisa’nın 1 Numaralı Şer’ iyye Sicilindeki Osmanlı Tarihi”, nşr. Z. Arıkan, Osmanlı Araşttrmaları, X (1990), s. 124. 
de zam yapılmıştı (s. 11, 40). Şehzadenin hareminin son derece mutavazi olduğu da anlaşılmaktadır. Üç kadını dışında 10 cariye sayılmıştır. Haremde bir kethuda kadın, beş ferraş/cariye, üç sazende, iki çamaşırcı bir külhancı kadın ve bir de çocukların "daye"si bulunuyordu (s. 9, 33). Darüssaade ağası Hüsrev Ağa idi, onun dışında saray ağası olarak hazinedarbaşı Mercan Ağa, kapıağası Hüseyin Ağa ve kiler ağası Murad Ağa’nın adı geçer. Bunlar kendilerine verilen bal şerbetinin, şekerden yapılmış şerbetle değiştirilmesini talep etmişlerdi (s. 10). İlginç olan husus bulunması zor ve pahalı olan şekere olan taleptir. Defterde aile münasebetleri içinde özelikle Şehzade Selim'in Rüstem Paşa ile iyi ilişkiler içinde olduğu görülmektedir. Kızkardeşinin kocası olan Rüstem Paşa’nın talepleri gönderdiği adamına verilen hediyeler bunu açı şekilde ispatlar (s. 9). Hatta şehzadenin özel taciri durumundaki Ali'den Bursa'da istenen avarız vergisinin affı için Rüstem Paşa'ya mektup yollandığına dair bir kayıt bile vardır (s. 36). Üstelik babası da onun yanındaki önemli görevlilere zaman zaman İstanbul'dan in'amlar yolluyordu (s. 26, 44). Yine babasının ona şahin gönderdiğine dair kayıt mevcuttur (s. 21).

İkinci olarak defterde özellikle saray görevli çeşidiyle alakalı tevcih, ulufe artırımları ve yeni istihdamlar dolayısıyla dikkat çekici bilgilere ulaşmak mümkündür. Bunlar ayrıca saray hayatıyla alakalı ipuçları vermeleri bakımından önemlidir. Saraydaki hizmetli sayısı hakkında tam bir bilgi yoksa da kendisinden önce Manisa'ya gelen Şehzade Mehmed'in 500'ü aşkın görevlisi olduğu bilinmektedir. Şehzade Selim'in de bu kadar kalabalık bir hizmetli topluluğu olduğuna şüphe yoktur. Defterdeki çeşitlilik bu anlamda önemli ipuçları sağlar. Harem dışında Enderun halkı, gulamlar, divanda görev yapan bürokratlar ile bunların çoğu ulufesiz olan yardımcıları, ehl-i hiref topluluğu, mutfak, ahır, bahçe görevlileri ile Manisa Sarayı adeta merkezdeki sarayın bir minyatürü konumundaydı. Sadece çadır mehterlerinin görevli sayısı 54’ü buluyordu (s. 32). Ayrıca çalıcı ve alem mehter görevlileri de mevcuttu. Çalıcı mehterlerin bir mehterbaşı olmak üzere 14 üstad çalgıcı ile bunların yardımcılarından oluştuğu belirtilmişti (s. 5). Mutfakta çalışan yemek pişiricileri, ekmekçiler, helvacılar, kiler görevlileri hayli kalabalık idi. Bunlardan mesela sadece "tabbahin" denilen aş̧̧ı yardımcılarının sayısının 25 olduğu belirtilmiştir. 35 kadar mutfak görevlisinin mevcudu kifayet etmediği için 18 kişilik yeni bir takviye daha yapılmıştır (s. 35). Sarayın Enderun kısmındaki oğlanlar için onlara yazı ve kitabet sanatını öğreten bir hocanın (Muhyiddin Efendi) mevcud bulunması da dikkat çekicidir. Ondan "hat mu’allimi, kâtib-i kütüp" tarzında söz edilmiş olması tanımlama ve görev fonksiyonu bakımından belirleyicidir (s.21, 22, 26). Bundan hareketle sarayda bir kütüphanenin var olduğunu söylemek de mümkündür. Saray tabibi ise Abraham adlı bir yahudiydi, 
ayrıca bir cerrah, bir kehhal (göz doktoru) de görev yapıyordu (s. 15). Padişahın hocası olan Şemseddin Efendi'nin aynı zamanda ders verdiği 6 danişmendi mevcuttu, bütün bunlara saraydan tahsisat veriliyordu (s. 21). Saray hayatı içinde rutin idari işler yapan, gündelik ihtiyaçlara yönelik faaliyette bulunanlar yanında harem halkını ve şehzadeyi eğlendiren kimselerin de yer aldığı anlaşılmaktadır. Özellikle saz çalıp şarkı söyleyenler (sâzende ve gûyende) ile zil, nefir, nakkare çalanlar yanında sarayda tıpkı Topkapı Sarayı'nda olduğu üzere bir arslanhane olduğu kayıtlıdır. Burada arslan sayısı hakkında bilgi olmamakla birlikte 5 arslancının görev yapmakta olması, bu rakamın hiç de az olmadığına işaret etmektedir (s. 40). Bunlarla bazı gösteriler yapıldığını tahmin etmek hiç zor değildir. Ayrıca bizzat şehzadenin huzurunda güreşen pehlivanlar sarayda istihdam edilmişti (s. 46). Pehlivanbaşılık görevi ile güreş gösterisi sırasında dua okuyan bir pehlivan duacısının yani cazgırın maaşlılar arasında yerini almış olması bir başka ilginç tesbittir (s. 38). Pehlivanların bazılarının nefir, nekkare gibi çalgıcılar olması da (s. 24, 47) bu anlamda, bu ocağın gösteri takımı olarak mehterhaneye bağlı olduğuna işaret eder. Zaman zaman ehl-i hiref topluluğu içinde kuyumcu veya saraçların özel yaptıkları eyer takımı, sahan gibi bazı eşyaları şehzadeye sunarak caize bekledikleri de görülmektedir.

Defterden çıkarılan bir başka önemli husus hakkında hemen hemen çok az bilgi olan Manisa Sarayı'nın durumudur. Bu saray son formunu II. Murad'ın tahttan çekilip şehre yerleştiği sırada almıştı. Daha sonra buraya gelen şehzadeler

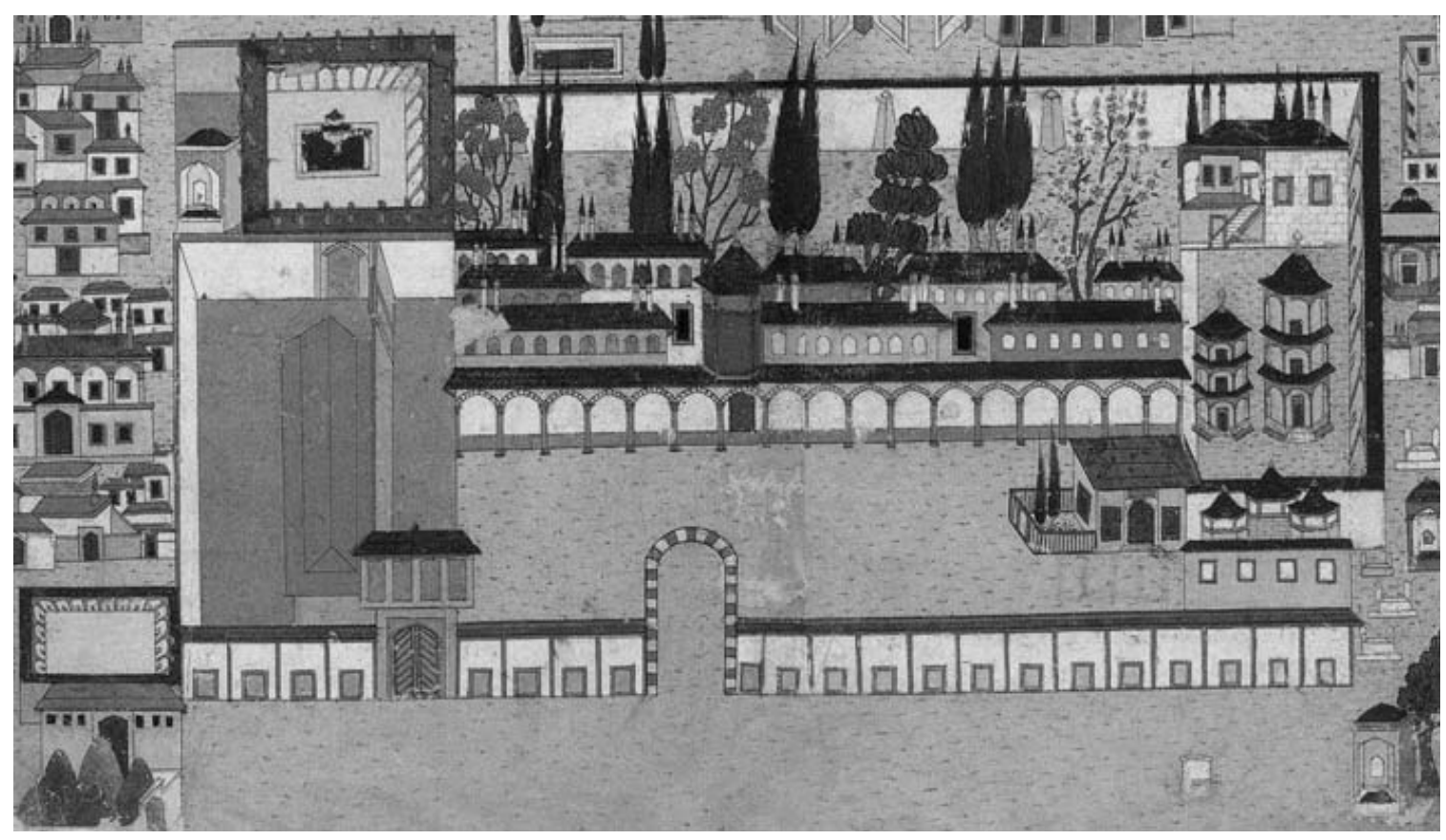

XVI. yüzyıl sonlarında Manisa Şehzade Sarayı (Talikîzâde, Şemâilnâme-i Âl-i Osman, TSMK, III. Ahmed, nr. 3592, 10 ${ }^{\mathrm{b}}-11^{\mathrm{a}}$ ). 
saraya yeni ekler yapmış olmalıdırlar. Fakat bunlara dair elde herhangi bir bilgi bulunmamaktadır. Saray, Manisa'nın Hatuniye Camii'ne yakın düzlük alanda bağ ve bahçeler içinde yer alıyordu. XVI. asrın sonlarına ait yegâne minyatüründe ${ }^{16}$, buranın fazla sayıda müştemilatı olduğu rahatlıkla görülebilir. Şehzade Selim Manisa'ya geldiğinde sarayı biraz harap bulmuş olmalıdır. Nitekim annesi Hürrem Sultan’a yazdığı bir mektupta sarayın duvarlarının su geçirdiğini, rüzgârdan etkilendiğini belirterek tamire ihtiyacı olduğunu bildirmişti ${ }^{17}$. Şehirdeki ilk kışının çok sert geçmiş olması sarayın tamiri ve yeni binaların eklenmesi işini gündeme getirdi. Defterdeki kayıtlardan anlaşıldığına göre sarayda öncelikle ağaların oturduğu yerdeki sundurma yükseltilerek genişletildi. Ardından mutfak kısmına yeni bir buğday değirmeni kısmı eklendi. Ayrıca ahırların bulunduğu yerin önünde yeni bir meydan yapıldı. Ardından küçük oda genişletildi, saraya bir orta kapı yapıldı, üzerine bir kasr inşası tamamlandı, ahırın yakınındaki boş alan havlu haline getirildi, ayrıca bir de mehterhane yeri ihdas edildi (s. 36). Özellikle bu sonuncular, Sarayın merkezdeki saraya benzer bir mimari şekle bürünmesini sağlamış olmalıdır. Özellikle inşa edilen kasrın minyatürdeki yerini tahmin etmek ilginç olacaktır. Kasrın ve daha doğrusu saraydaki tadilatın Hürrem Sultan'ın Manisa ziyareti arifesinde tamamlanmış olması da bir tesadüf olmamalıdır. Kasrın inşasında hizmet edenler, bina emini olarak sipahioğlanları zümresinden Mehmed b. Piri, masraf kâtibi Yusuf b. Velid, Behram b. Musa Çavuş ile saraydarlardan

16 Talikizâde'nin Şemâilnâmesi'nde yer alan Manisa minyatüründe esas figür Şehzade Sarayı olup burada binanın bütün parçaları hayli gerçekci bir perspektifden verilmiştir. $\mathrm{Bu}$ minyatüre dayalı yapılan tanımlamalarda, Edirne ve İstanbul saraylarında olduğu gibi bir "Kasr-1 âdil" bulunduğu, bunun kare planlı ve kurşun kaplı olduğu, sarayın genel olarak yatay konumda dikdörtgen binalar topluluğu halinde yapıldığı belirtilir. Sarayın etrafı duvarlarla çevrili olup bir revak boydan boya yatay olarak burayı ikiye bölmekte idi. Ön avluda sağdaki küçük binanın Divan kasırı olduğu tahmin edilmiştir. Bazı yazarlar ise bunun hastane binası olduğu görüşündedir. Uzun revak gerisinde yer alan saray binaları arkadaki saray bahçesiyle son bulmaktadır. Yapı grubunun sol kısa kenarındaki kırmızı çatılı binanın harem veya has ahır olduğu beyan edilir. Ancak bu binanın açıldığı kare şeklindeki etrafı revaklı, ortasında havuz olan avlulu binanın Topkapı Sarayı örneğindeki gibi harem yapılanmasıyla benzerlik arzettiği üzerinde durulur. Avlunun sağ köşesinin üstündeki ikiz gibi görünen biri geniş balkonlu (hayat) diğeri kapalı iki binanın harem olmayıp küçük köşkler olma ihtimali öne sürülür. Sol alt köşede yer alan revaklı dikdörtgen bina ile önündeki yüksek girişli, pencereleri tepede olan tek bina tasviri ise önünde saman yığılı olması dolayısıyla ahırları işaret etmektedir (bk. E. Üçbaylar, "Saray-ı âmire (Manisa Sarayı), Manisa, I (1982), s. 39-46; İ. Bilgin, "Manisa Sarayı", 9. Milletlerarası Türk Sanatları Kongresi, Bildiriler, Ankara 1983, s. 41-54).

17 Bk. F. M. Emecen, Manisa Kazast, s. 104; TSMA, nr. E. 6058/1. 
Hacı Mustafa b. Mehmed idi (s. 48). Bu bilgiler Manisa Sarayı hakkında sadece mimari açıdan değil bir ikametgâh olarak ihtiyaçlar çerçevesinde nasıl tevsi edilmiş bulunduğunun göstergesidir. Ayrıca Manisa Sarayı’nda esaslı mimari değişikliklerin bu dönemde gerçekleştirilmiş olduğunu da ortaya koyar. Merkezdeki bu saray dışında şehzadenin yazın çıktığı Bozdağ'da Gölcük adlı mevkide de bir sarayın bulunduğunu bu defterdeki kayıtlar açık şekilde gösterir (s. 37). Bugün bu sarayın kalıntıları üzerinde bir arkeolojik yüzey çalışması yapılmaktadır ${ }^{18}$. Burası Birgi kadılı̆̆ına yakın olduğu için şehzade yaylağa çıktığında kadı onu karşılamış ve hediyeler sunmuştu. Şehzade Selim yaylağa çıkmadan üç ay önce buradaki sarayın elden geçirilmesini emretmişti.

Defterde bunlar dışında bazı müteferrik konular arasında şunlara değinilebilir. Şehzade bilhassa duacı olarak nitelendirilen bazı dini şahsiyetlere verilen paralarla dua istimdad etmiştir. Bunlar arasında Konya’da Mevlana Türbesi’nde cüz tilavet eden Mevlânâ Şuca Efendi dikkat çeker (s. 46). Ayrıca Sarı Işık adlı bir azizin, Manisa'da ilim ehli olup dini nasihatlarda bulunan Mehmed adlı bir şahsın ve bir hatibin adı geçer (s. 44). Yine İzmir taraflarında ava çıkıldığında uğradığı Samed Baba Tekkesi'ne bir mescit ilave edilmesi için 2000 akçe tahsis edilmiş, bunun 1000 akçesi inşaat, geri kalanı ise orada görev yapacaklar için ayrılmıştır (s. 44). Defterdeki kayıtlar içinde bir diğer dikkat çekici husus, bazı saray görevlilerinin sılalarına gitmek için izin istemeleri keyfiyetidir. Divan ruznamecisi, memleketi olan Edirne'ye gitmek için iki aylık bir izin talebinde bulunmuş; vezzan olan bir diğeri ise yine Konya'ya izine gitmek için icazet almıştır (s. 43) . Bunların yanı sıra Menemen'e bağlı Alayuntlu adlı köyden Selime adlı bir kadının da babası olan Saruhanoğulları'ndan Abdurrahman'ın evinde hazine/define sakladığını ihbar ettiğine dair arz dikkati çeker. Şehzade birinin yollanıp durumun tahkik edilmesini istemiştir (s. 43). Bu sonuncu kayıt aradan uzun bir süre geçmiş olmasına rağmen Saruhanoğulları'na mensup bazı aile üyelerinin değişik yerlerde yaşadıklarını gösterir. Ayrıca aile fertlerinin hatırı sayılır ölçüde mal biriktirdikleri de ortaya çıar.

Netice olarak bu kayıtlar, diğer şehzade divan defterlerinin dışında, tamamen şehzadenin kendi insiyatifindeki konuları; onun merkez dışı idari tasarrufunu gösterir. Aynı zamanda şehzadenin idari yetkilerinin adem-i merkeziyet derecesinde olduğu yolundaki eski tartışmayı ilk anda doğrular ${ }^{19}$. Fakat hemen hemen aynı

18 Prof. Dr. Veli Sevin ve Prof. Dr. Necla Arslan Sevin tarafından Bozdağ /Gölcük'te bazı kalıntıların varlığı tesbit edilmiştir: İlk tesbitler için bk. Necla A. Sevin, "Bozdağ ve Gölcük’teki Yok Olan Osmanlı Yayla Sarayları”, Küçükmenderes Harman, I/5 (Ödemiş, Mayıs 2012), s. 14-15.

19 Bk. F. M. Emecen, Manisa Kazası, s. 40. 
yıllardan itibaren başlayan Şehzade divanından çıkan kayıtları havi defterler, keza merkezdeki şehzade tekliflerini ihtiva eden başvurular ve aracılıklar, bunun iddia edildiği ölçüde "merkezkaç" bir yapıyı öngörmediğini açık şekilde ortaya koyar. Ayrıca defterden şehzade kapısındaki personelin menşeini anlamak ve bunların nasıl ve ne şekilde hizmete alındıklarını tesbit etmek de mümkündür. Bunların bir bölümünün yakın görevlilerin akrabaları, hizmetlileri ve tanıdıkları olması, "nepotizmin" açık yansımaları olarak yorumlanabilir. Fakat bunun ötesinde mahallî unsurların şehzade kapısı vasıtasıyla ileride merkezdeki saraya kadar uzanacak bir yol ve fırsatı da sağlamış olduğunu da gözden kaçırmamak gerekir. Klasik çağ boyunca şehzadeler vasıtasıyla taşra-merkez ilişkisinin ve karşıllıklı etkisinin, sadece kültürel değil, bürokratik ve siyasi geleneklerin oluşmasındaki rolü bu anlamda önemlidir. Patrimonyal devlet oluşumu teorilerine hevesle sarılmadan önce, en azından taşranın bu etkisinin durumu dikkatle yeniden düşünülmelidir. Taşradan gelerek payitahtta cülus eden ve maiyetindekileri kilit görevlere getiren padişahın iktidarını güçlendirmede bu taşra güçlerin önemli bir faktör olduğu, XVII. yüzyılda taşrayla ilişkisi kesilmiş bir şekilde tahta çıkan padişahların durumu düşünüldüğünde, üzerinde durulması gereken önemli bir teorik zemin sağlar. $\mathrm{Bu}$ çerçevede de söz konusu şehzade divanına ve sarayına ait defter külliyatını, klasik çă̆ Osmanlı idari yapısının mahiyetini belirlemede göz ardı edilemeyecek ölçüde önemli bir hale getirir.

Bütün bunların dışında söz konusu defter diplomatika özellikleri ile farklı bir türü ortaya koyar ve taşra bürokrasisinin mahiyeti hakkında hayli erken sayılabilecek ipuçlarını aksettirir. Şehzadenin varlığının yerel ölçekteki sosyal ve iktisadi etkileri hakkında da dikkate değer verilere ulaşmak mümkün görünür. Yine Manisa şehir tarihi temelli bir araştırma bakımından defterin önemli bilgileri haiz bulunduğunu belirtmek yanlış olmaz. Bu bakımdan merkezi bürokrasinin benzeri defter serileri açısından hayli farklı bir türü olması hasebiyle defterin tam bir metnini deşifre ederek buraya eklemenin uygun olacağını düşündük. Metni hazırlarken defterdeki ciltleme hatasından kaynaklanan sahife karışıklığını düzelterek verdik. Orijinal metinde s. 2'deki kayıt, tarih sırası itibarıla s. 35 'in önüne; s. 4-5'teki kayıtlar da yine s. 7'nin önüne getirildi. Böylece defterdeki tarih sırasına göre düzenleme yapılmış oldu, sahifeler doğru yerini buldu. Sunulan arzlar, kaziye veya tafsil vb. başlıklar altındaki kayıtların üzerinde yer alan önemli bir bölümü şehzadenin olurunu ve fikrini temsil eden buyruldular ve hatlar metinde köşeli parantez içinde koyu hurufatla verildi. Defterin orijinal sayfaları da yine metinde gösterildi. Metin yeni harflere aktarılırken mutedil bir çeviri yazı sistemi tercih edildi. Okunamayan veya defterde tahribat sebebiyle silik çıkan kelimeler de yine 
parantez içinde (...) şeklinde belirtildi. Ayrıca defterdeki iptal edilen kayıtları ifade etmek üzere metnin üzerine çekilen "terkin" ifadesi, yine parantez içinde metnin yanına italik olarak eklendi. Metinde bazen sayfa kenarına eklenen ve genellikle yapılan tayinler dolayısıyla o görevin daha önceki hizmetli sayısı ve aldıkları yevmiyeleri gösteren kayıtlar da yine köşeli parantez içinde ilgili ibarenin yanında gösterildi. Burada kullanılan kısaltmaların açılımı köşeli parantez içinde tamamlandı. Ayrıca keşideli başlıklar üzerinde yer alan yatay şekildeki ta’yin, nakluhu, baki ve sahh ifadeleri ilgili başlı̆̆ın yanına italik olarak eklendi. 
Metin: BA, D.BŞM, nr. 23.

$(\mathrm{s.3})^{*} \quad[$ boş $]$

(s.6) Tafsîl oldur ki, mahrûse-i Konya’dan Manisa’ya gelince hızmet eden saraç şâgirdlerinden saraç olmak murâd edenin ve ulûfesiz hızmet edüp saraç olmak murâd edenin ve mezkûr şâgirdlerin yerine şâgird olmak isteyen ve nalband lâzım olup nalbandlık isteyen ve nalbandların şâgirdleri az kalup şâgird olmak isteyen ve hâssa atlara bir seyis dahi lâzım olup hâssa seyisler şâgirdlerinden seyis olmak isteyen bunlardır ki zikrolunur.

Ulûfeli şâgirdlerdir ki saraç olmak murâd edinirler [üçer akça ulûfe ile saraç olmak buyruldu, el-vâki' fî-gurre-i Safer sene 951] ta yîn

Cafer b. Nazar, şâgird, 1; Ferhad b. Kethudâ, şâgird 1; Hüseyin hîş-i Sinan, 1; İlyas b. Yusuf, 1; Hasan b. Hızır, 1; Mehmed b. İsmail, 5, Çavuş şud, becayiş-i Mustafa b. Hamza (terkin); Hamza hîş-i Kemer Ali, 1; Pervane, Moraî, 1; Mehmed Semendire, 1

Yekûn neferen 8, fî 3 .

[cemâ‘at-i sarracîn, neferen 35. Mevâcib-i mezbûrân, fî 5, fî 4, fî 3]

Ulûfesiz hızmet edüp saraç olmak isteyen bunlardır [üçer akçe ulûfe ile saraç buyruldu, fî târihin minhu] ta' $y \hat{i n}$

Mehmed b. Esedullah; Kurd b. Yusuf

Ulûfesiz şâgirdlerdir ki hızmet edüp saraç şâgirdi olmak isteyen bunlardır [birer akça saraç şâgirdi buyruldu, fî târihin minhu] tajîn

Cafer b. Abdullah; Mustafa b. Abdullah; Mustafa b. Mehmed, şâgird; Mehmed b. Abdullah; İbrahim b. Abdullah [cemầat-i şâgirdân-1 sarracîn, neferen 14]

Ulûfesiz hızmet edüp bârgîrlere nalband olmak isterler [üçer akçe ile naâl olmak buyruldu, fî târihin m.] ta'yîn

* Defterin orijinalinin sonradan yapılan hatalı sayfa numaralandırılması, burada düzeltilmiştir. s.2 ileride s.35'ten sonraya, s. 4-5 ise 6 ile 7. sayfa arasına alınmıştır. 
Mehmed b. Ömer; Ahmed b. Üveys

[cemấat-i nalbandân-1 bârgîrân-1 tavîla, neferen 2, fî 3]

Ulûfesiz hızmet edüp nalband şâgirdi olmak isterler [birer akçe ile şâgird buyruldu, fî târihin m.] ta' yîn

Alagöz b. Abdullah; Pervane b. Abdullah

Yusuf b. Abdullah (terkin)

[şâgirdân-1 nalbandân-1 kadîm, 1 nefer, fî 1]

Ulûfeli seyis şâgirdidir, üstâd olmak ister [dört akçe ile seyis buyruldu, fî târihin m.] ta'yîn

Hüseyin b. Haydar, şâgird, 1; hâssa atlara seyis olur [cemấat-i seyisân üstâd-ı hassa, neferen 17, fî 4]

(s.4) Defter-i tezkire-i arz ki der-mahrûse-i Manisa vâki' şude el-vâki` fî 12 Cemâziyelâhır sene 951

Tafsîl oldur ki Anadolu Beylerbeyisi İbrahim Paşa Hazretleri'nin hızmetkârların ve saraçların ve seyislerin ve devecilerin ve harbendelerin ve şâgirdlerin beyân eder ki zikrolunur

Ser-bevvâbîn, 1 nefer, nakdiye: 5000. Câme-i çatma, a'lâ serâser, 1 sevb.

Altıbin akçe timara mutasarrıf imiş, dört bin akçe terakki inâyet vech görülür, kendü zeâmet murâd edinür, paşa bendenüzün oğulluğu imiş.

Cemâ'at-i hızmetkerân ve gayrihu, 24 neferen. $t a^{\prime}$ yîn

Sarrâcîn, neferen 6, fî 500: 3000

Kâtib, 1 nefer, 500

Ser-bölük, 1 nefer, 500

Naâl, 1 nefer, 400

Ulûfeciyân, neferen 9, fî 300: 2700

Bevvâbîn, neferen 6, fî 200: 1200

Yekûn: 8300

Cemâ‘at-i seyisân, neferen 6, fî 200, yekûn 1200. ta'yîn 
Şâgirdân-1 mezkûrîn, 1 nefer, 50, yekûn: 1250

Cemâ'at-i harbendegân, neferen 9. ta'yîn

Ser-harbende, 1 nefer, câme-i benek, ednâ, 1 sevb

Harbendegân, neferen 7, fî 200: 1400

Şâgirdân-1 mezkûrîn, 1 nefer, 50

Yekûn: 1450

Cemâ'at-i şütürbânân, neferen 80. ta'yîn

Sarbân 1 nefer: câme-i benek, evsat, 1 sevb, nakdiye: 500

Ser-bevvâb neferen 2: câme-i benek, ednâ, 2 sevb

Şütürbânân, neferen 44, fî 200: 8800

Şâgirdân-1 mezkûrîn, neferen 33, fî 50: 1650

Yekûn şütürbânân: 10950

Yekûn nakdiye: 26950, câme: 5 sevb

[Bu ta yîn olunanlar makbûl olup verilmek emr olundu, fî 12 Cemâziyelâhır sene 951]

(s.5) Kazıyye oldur ki çalıcı mehterlerine beşbin akçe in âm ve mehterbaşına bir hil'at buyrulmuş, emr-i şerîfiniz ne ise inâyet buyrula [mezkûrlara in âm buyruldu] ta' yîn

Ser-mehterân, 1 nefer

Mehterân-1 üstâd, neferen 14

Şâgirdân-1 mezbûrân neferen, 3

Kazzyye oldur ki, mahrûse-i Bursa'da emr-i şerîf ile emânet konulan otak-1 şerîfin gelmesi husûsunda emr-i şerîfiniz neyse inâyet buyrula [getürülmek buyruldu]

Mezbûr otak-1 humâyûnu getürmeye sekiz katar deve lâzımdır Kazıyye oldur ki, ağaların mevâcibinin müsterekası husûsu arz oluna

(s.7) Tafsîl oldur ki şehzâde-i civân-baht -tâle bekahu- hazretlerinün kadîmden hâssa arabaları altı kıt'a olup ve mahrûse-i Konya'dan dahi beş kıt'a araba düzülüp ve hazret-i pâdişâh-1 âlem-penâh -hullide mülkuhu- cânibinden iki kıt'a araba verilüp ve cümle 
on üç araba olup ve ba‘zı kimesnelerden dahi Bursa'da dört kıt‘a araba alınup cem'an on yedi kıt'a araba olup mezbûr dört arabalara arabacı lâzım olunu gelip mezbûr kimesneler mahrûse-i Bursa'dan Manisa'ya gelince hızmet edüp arabacı olmak murâd edinirler [üç akça ulûfe ile arabacı olmak buyruldu. Fî $18 \mathrm{C}$ sene 951] ta'yîn

Cafer Priştine; Hacı Hüseyin Ilıca; Hızır b. Mustafa, kul; birâder-i Mustafa, kul; Yusuf Trabzonî; Mehmed Kastamonî; Hürrem Edirne; Timur Üsküdar

[Cemâ‘at-i arabaciyân ve neccârân ve haddâdân, neferen 30, fî 4, fî 3 . Arabaciyân neferen 26, neccârân neferen 3, haddâd neferen 1; Şâgirdân-1 mezkûrîn, neferen 5, fî 1]

Cemâatat-i sarrâcîn

Mehmed b. İsmail, 5

Âsitâne-i sa âdetten gelen Çaşnigir başı Sinan Ağa iltimâs edüp çavuşluk sadaka olunup mezkûrun gediği Mustafa b. Hamza'ya tevcîh olunmak ricâsın eder, emîr-i âhur bendeleri [üç akçe ulûfe ile saraç buyruldu, fî $18 \mathrm{C}$ sene 951] ta' yîn

(s.8) Kazıyye oldur ki kilerci başı kulunuz (yırtık) hâssa-i humâyûn için ikişer yüz dirhemden iki kıt'a şem'-i kâfurî ve ikişer yüz dirhemden üç kıt'a bal mumu ve hâdis olan has odaya bir kıt'a çırağlar içün yüz ellişer dirhemden dört kıt’a bal mumu isterler, emr-i şerîfiniz nedir inâyet buyrula ki sâbıkda hâssa-i humâyûn içün ikişer yüz dirhemden iki kıt'a bal mumu verilirdi, hâliyâ bu uslûb üzere olması. [iki kıt'a şem'-i kâfưrî 100 dirhemden bey hazretlerine bir dahi kendüler hızmetine bir nefer, 100 dirhem biri kethudâ hatuna ve dört dahi bir nefer ağalara iki dahi birer nefer bostancılara cümle on kit'a bal mumu oldu, üç kıt’a (?), üçyüz dirhem olup arz olundukda böylece buyruldu, fî 25 C sene 951]

Ve Saray-1 âmire için dört himl kar isterler ki her himli yirmibeşer akçe olur, emr-i şerîfiniz nedir [yevmî iki yük himl buyruldu, fî 26 C sene 951]

Kazıyye oldur ki merhûm ve mağfûr Sultan Mehmed -tâbe serâhu- lalası Halil Paşa'ya hil'at-i serâser mi emr olunur veya ağır kadife çatma

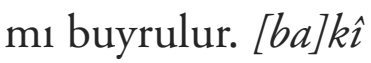


Ve Sakız'dan gelen elçi kâfirine emr-i şerîfiniz üzerine hil'at ne cinsden verilmek buyrulur. [ba]kî

Kazıyye oldur ki sâbıkan Saray-ı âmire saraydârına iki sahan aş ve iki pâre et ve iki zevc fodula ve Saray-1 âmire meremmetçisine iki sahan aş ve iki pâre et ve iki zevc fodula ve altı nefer bostan oğlanına dört sahan aş ve dört pâre et ve altı zevc fodula verilirmiş, hâliyâ girü ricâ ederler [âdet üzre bunlara ta'âm buyruldu, fî 25 C sene 951]

Kazıyye oldur ki bostan oğlanlarından Niğbolulu Davud ulûfesiyle baltacı olmak ricâ eder

Fî yevm 1

Kazıyye oldur ki bostan oğlanlarından mahrûse-i Konya'dan Manisa'ya gelince baltacılık hızmetin edüp hâliyâ baltacı olmasın ricâ ederler [altı nefer gilmân ikişer akçe ile baltacı ta'yîn olundu, fî $26 \mathrm{C}$ sene 951]

Haydar Yanbolu, 1; Mehmed Niğbolu, 1; Nasuh Siroz, 1; Nasuh Manastır 1; Mustafa Dimetoka, 1; Davud Niğbolu, 1

Mevâcib-i şâgirdân, fî sene 3

(s.9) İzdiyâd ve ibtidâ-i mevâcib-i mezkûrîn an-cemâ'at-i dârüssa âde-i Enderûnî [buyruldu, fì 26 C sene 951] ta'yîn

Kethudâ Hatun, 20. y[evm] 15, terakki 5

Ferrâşân, an-cevârî: neferen 5 an-kadîm, neferen 3, fî 5, k[adìm] fî 4; fî 1 an-sâzendegân-1 kadîm, 1 nefer, 5; k[adîm] 2, k. 3 an-cedîd ibtidâ kerde, 1 nefer, 5

Sâzendegân, neferen 3 an-kadîm, neferen 2, fî 4, k[adîm] 2, k. fi 2 an-cedîd ibtidâ kerde, 1 nefer, 4

Vâlide-i şehzâdegân, neferen 2, fî 8: k[adîm]. fi 4, k[adîm] fî 4 . an-ferraşân

Câmeşûyân, an-kadîm, neferen 2, fî 3: k[adîm]. fi 2, k[adîm] fi 1

Dâye-i şehzâdegân, 1 nefer, ibtidâ, fî 2 
Külhanbân, 1 nefer, ibtidâ, fî 2

Kazıyye oldur ki Seydi Ahmed nâm kimesne sâbıka üç akça ulûfe ile nakkaş olup hızmetten ferâgat edip yerine bir nakkaş dahi lâzım ve ehem olmağın Ali b. Abdullah üstâd nakkaş olup san'atında tamâm mâhir olmağın mezbûrun yerine terakkiyle nakkaş olmasın ricâ eder [beş akçe ulûfe ile nakkaş buyruldu, fî 3 Receb sene 951] nakluhu

Kazıyye oldur ki kapucu cemâ'atinden çavuşluk sadaka buyrulan meş'aleci Mehmed'in meş'alesin bevvâblar bölük başılarından Yusuf bölükbaşına inâyet olup mezbûr Yusuf bölükbaşının yerine bevvâblardan Mustafa birâder-i Ali'ye inâyet olmasın kapucubaşı bendeleriniz ricâ eder ve mezbûr Mustafa bevvâbın gediğine Ali b. Mehmed bevvâb olmasın Rüstem Paşa Hazretleri sâbıka iltimâs eylemişlerdir [meş'aleci beş akçe ile kapuculara dört akçe ile buyruldu, fî 3 Receb sene m. ve Yusuf bölükbaşı yerine bölükbaşı olan Kapucu Mustafa birâder-i Ali'ye bir akçe ziyâde buyruldu, fî târihin m.] naklubu

Mevâcib-i mezbûrîn, bevvâbîn, fî 4; meş'aleciyân, fî 5

Kazıyye oldur ki cihâz mühimmatıyçün yirmibin akçe verile deyü fermân olunmağın yirmibin akçe der-kise olup Hüsrev, Dârüssa âde ağası Hüsrev Ağaya teslîm olundu

Kazıyye oldur ki Hazinedarbaşı Mercan Ağa bendenüz bevvâblardan Mehmed Bosna'nın meş'aleci olmasın ricâ eder. [yevmî beş akçe ile meş'aleci buyruldu, fî râbi'-i Receb sene 951] nakluhu

Meşáaleciyân-1 kadîm, neferen 7; Mevâcib-i meşáaleciyân fî yevm 5

Kazzyye oldur ki Dârüssa âde ağası Hüsrev Ağa bendenüz ulûfesine terakki olmasın ricâ eder, fî yevm 15. [beş akçe ziyâde olmak buyruldu, fî 4 m.] ta yîn

(s.10) Kazıyye oldur ki, mezbûr cemâ'atlerin (yırtık) ba'z1 girihte olup ve ba'zının hızmeti kesîr olmağın mezbûrların şâgird olması ricâ ederler.

Şâgirdân-1 tabbâhîn

Yahya b. Abdullah, becây-1 Yusuf ki girihte şud; Mehmed b. Abdullah, ibtidâ; Behram b. Abdullah; Yusuf b. Abdullah [bu 
dört nefere yevmî buçuk akçe ile buyruldu, fî 4 Receb sene 951] naklubu

[Şâgird-i tabbâhîn-i kadîm neferen 25. Minhâ girihte neferen 1; bâki mevcûd neferen 24, fî 2 ve 1,5$]$

Şâgirdân-1 habbâzîn

Malkoç b. Abdullah, becây-1 Kasım b. Abdullah ki girihte şud; Mehmed b. Abdullah, becâ-yı Hamza b. Abdullah ki girihte şud; Yusuf b. Abdullah becây-1 Mehmed b. Abdullah ki girihte şud; Hızır b. Abdullah; Mustafa b. Abdullah [beş nefere birer buçuk akçe ile buyruldu, fî târihin minhu] nakluhu

[Şâgirdân-1 habbâzîn-i kadîm, neferen 13. Minhâ, girihte neferen 3; bâki mevcûd neferen 10, fî 2 ve 1,5]

Şâgirdân-1 helvacıyân

Hüseyin b. Abdullah, becây-1 Mahmud ki gaybet kerde; Cafer b. Abdullah, becây-1 Mehmed ki girihte; Mustafa b. Abdullah, becây-1 Mehmed-i diğer ki girihte şud [üç nefere birer buçuk akçe ile buyruldu, fî târihin minhu] nakluhu

[Şâgirdân-1 helvaciyân-1 kadîm, neferen 7. Minhâ girihte neferen 3; bâki mevcûd neferen 4, fî 1,5]

Şâgird-i kilâr

Hasan b. Abdullah, Bosna [bir buçuk akçe ile buyruldu] naklubu

[Şâgirdân-1 kilâr an-kadîm neferen 4, fî 1,5]

Şâgird-i câmeşûy

Hızır b. Abdullah, becây-1 Mustafa ki gaybet kerde [bir buçuk akçe ile buyruldu] naklubu

[Şâgirdân-1 [kadîm]-i câmeşûyân, neferen 4; minhâ, girihte 1 nefer; bâki mevcûd neferen 3, fî 1,5]

Kazıyye oldur ki Saray-1 âmire ağalarından kapu ağası ve hazînedârbaşı ve kilarcıbaşı ve Dârüssa âde ağası Hüsrev Ağa bendelerinüze şimdiye değin aselî hûşâb verilirdi, hâliyâ sükkerî olmasın ricâ ederler [iki günde hûşâb içün bir kıyye sükker mezbûrlara buyruldu, fî 4 (Receb) sene 951] 
(s.11) Kazıyye oldur ki şehzâdelere onar akçe ulûfe ibtidâen ve şehzâde vâlidesine dört akçe ulûfesin üzerine (yırtık) akçe izdiyâd ve dâyesine iki akçe ulûfe ibtidâen buyrulmasın emr-i şerîfiniz ne ise inâyet buyrula [vech-i meşrûh üzere buyruldu, fî 10 Receb sene 951] naklubu

Şehzâdegân, 3 nefer; vâlide-i şehzâde, 1 nefer, fî yevm 4; dâye-i şehzâde, 1 nefer

Kazıyye oldur ki tezkere-i şerîfe vârid olup sipâhi oğlanları ağası Yahya Bey'e yirmi bin akçe karz verilsin deyü fermân olunmuş, emr-i şerîfiniz ne ise inâyet buyrula [yirmibin akçe bi-tariki'l-karz verilmek buyruldu] nakluhu

Kazıyye oldur ki, altı nefer baltacı oğlanına birer akçe ziyâde buyrulmuş, emr-i şerîfiniz ne ise inâyet buyrula [ziyade birer akçe olmak buyruldu, altı nefer [o]ğlanlara, fî̀ 10 Receb sene 951] nakluhu [mevâcib-i mezbûrîn, 6 nefer, fî 2]

Kazıyye oldur ki, mahrûse-i İstanbul'dan on kit'a serâser gelsin deyü fermân olunmuş, a'lâ mı evsat mı emr olunur inâyet buyrula [İstanbul'dan gelmek buyruldu, fî 10 Receb sene 951]

Kazzyye oldur ki, kâfurî mum işlensin deyü fermân olunmuş idi, hâliyâ bu yerlerde kâfurî mum kıllet üzerine bulunur, amma iki akçe ulûfe ile mumculuk hızmetin edüp ve dört akçe ulûfe ile arabacılık hızmetin eden Hasan bendenüz ol hızmetin uhdesinden gelür kimesneler olup amma şol şartla ki altı akçe ulûfesi mumculuktan olup ve bir akçe ulûfe ile bir şâgird dahi verilüp bu tarîk üzere ihsân buyrulursa kâfurî mum işleyüp yetüştürmesine uhdesine alur, bu bâbda emr-i şerîfiniz ne ise inâyet buyrula [dört akçe harçlık ref olunup yevmî altı akçe ulûfe ile mumcu olmak ve bir akçelik bir şâgird verilmek buyruldu, fi târihin minhu] nakluhu

Şâgird Yusuf, mu'tak-1 Hasan el-mezbûr

Kazıyye oldur ki kasabbaşı olan Mehmed bendenüz mahrûse-i Konya'da ve Konya'dan Manisa'ya gelince hızmet edüp ve hâliyâ gerü koyun getirmek içün Konya'ya gitmek murâd edinir, mezbûra bir hil'at verilmek münâsib gibi emr-i şerîfiniz ne ise inâyet buyrula [emr-i şerîf buyruldu ki bir benek kaftan verilmek buyruldu, fî 10 minhu] naklubu 
(s.12) Kazıyye oldur ki Tarhaniyat'ta vâki' olan Saray-1 âmirede bundan akdem saraydar olan Hızır b. Hacı bendeleri yevmî iki akçe ile hâliyâ saraydar olmak ricâ eder, emr-i şerîfiniz ne ise inâyet buyrula [gurre-i muharremden berü ulûfesi mukarrer olundu, yevmî iki akçe ulûfeleriyle, fî 11 Receb sene 951] nakluhu

Kazıyye oldur ki, Konya'da otuz re's davar alınıp üç seyis tutulup bi'l-fiil hızmet ederler ve mahrûse-i Bursa’da bârgîrler ziyâde olup dört nefer seyis dahi Bursa'dan hızmet edüp bi'l-fiil dahi hızmet ederler ve devlet ve saâdetle Manisa'ya gelindikde bârgîrler bir yere cem‘ olup mevcûd dört yüz on beş re’s bârgîr olup zikrolunan bârgîrlerin yüz on beş re'si cemấat-i müteferrikada olup andan ma âda üç yüz re's tavilada mevcûd olup mezkûr bârgîrlere otuz nefer seyis lâzımdır derler, şimdi mevcûd on dokuz nefer seyis vardır, on bir nefer dahi lâzımdır ki otuz nefer tamâm ola, emr-i şerîfiniz ne ise inâyet buyrula

Konyadan gelen bunlardır

Çepni-i Konya; Ahmed sipah Konya; Bilal Arap

Bursa'dan gelen bunlardır

Mustafa-i Beyşehir; Hasan b. Piri; İsmail b. Mustafa; Mustafa, şâgird-i Mehter

Manisàya geleliden berü hızmet ederler

Yakut Arab; Hasan Yalvac; Yusuf b. Yunus, şâgird; Abdullah Arap

Yekûn: 11 nefer fî 4 [buyruldu, hizmetleri gurre-i Cumâdelâhırdan berü imiş, ulûfeleri verile, fî 17 Receb sene 951] naklubu

[Mevâcib-i seyisân-1 bârgirân-1 tavila, fî 4. Asıl bârgirân-1 tavila: 415 re's. Minha der-cemâ‘at-i müteferrika, 115. El-bâki mevcûd der-tavila: 300 re's, beher 10 re's fî 1 seyisden neferen 30; mevcûd seyis neferen 19; lâzım olan seyis neferen 11]

Kazıyye oldur ki, devlet ü sa âdetle Manisa'ya gelindikde hassa estâr bir yere cem' olup yüz elli yedi re's davar olup her dokuz davara bir seyis lâzım olmağın on yedi nefer seyisten dört re's ziyâde 
olur bi'l-fiil on beş nefer mevcûd seyis olup iki nefer dahi ziyâde olmasın ricâ ederler, emr-i şerîfiniz ne ise inâyet buyrula

Lâzım olan bunlardır

Yusuf b. Mustafa, şâgird, 1,5; Haydar b. Mehmed, şâgird, 1

Yekûn neferen, fî 4 [buyruldu fî-gurre-i Cumâdelâhırdan ulûfeleri verile, el-vâki' fî 17 Receb 951] nakluhu

[Mevâcib-i sayisân-1 estâre-i kadîm, fî 4. Asıl estâre-1 hâssa: 157 re’s beher 9 re's fî 1 seyisden neferen 17. Mevcûd seyis neferen 15; lâzım olan seyis neferen 2]

(s.13) Kazıyye oldur ki, on üç katar katıra palan ve hassa estâra yüz elli kıt‘a kebe ricâ ederler, emr-i şerîfiniz ne ise inâyet buyrula. Ber-vech-i tahmîn beher palan fî altmışardan 3900, kebe beher kıt'a fî 50, 7500, cümle bahâ-i palan ve kebe 11400 akçe olur

Kazıyye oldur ki, Istabl-1 âmirede olan hüddâm içün mahlûl buçuğu ricâ ederler, emr-i şerîfiniz ne ise inâyet buyrula ki Âsitâne-i sa âdette kanundur [yevmî üç akça mahlûl buçuğu buyruldu, fî 17 Receb sene 951] ta'yîn

[Cemâ'at-1 Istabl-1 âmire neferen 25]

Kazzyye oldur ki, divân-1 âlî sakalarından İbrahim birâder-i Karagöz nâm saka fevt olup mezbûr müteveffânın yerine matbah-1 âmire sakalarından Mustafa birâder-i Ferhad üç akçe ulûfesiyle divân sakası olup ve mezbûrun yerine aşçılardan iki akçe ulûfe ile Mustafa birâder-i Yakub bir akçe ziyâde ile matbah sakası olmasın ricâ eder [buyruldu, fî târihin minhu, üç akçe ulûfesiyle ve bir akçe terakkıyle aş̧̧ı saka oldu] naklubu

Kazıyye oldur ki, on üç katar katırın rahtı tecdîd olup ber-vech-i tahmîn her katıra ne denlü akçe olduğun beyân eder ve yüz elli kit'a kebe hâs estâr içün ber-vech-i tahmîn 50 akçeden ne denlü olduğun beyân eder [katırların rahtı görülüp gemiler İstanbul'dan alup getürmek buyruldu, fî 17 Receb sene 951]

Beher katar, fî 1200: 15.600

Bahâ-i kebe berây-1 estâre-i hâssa, 150 kıt'a, fî 50: 7500

Yekûn: bahâ-i rahthâ-i esterân-1 sayisân ve bahâ-i kebe: 23.100 
(s.14) Kazıyye oldur ki yoğurtçu şâgirdlerinden (terkin)

Şâgirdân-1 mâstgerân

Hamza b. Abdullah, 1,5; gaybet kerde

Tâlib: Yusuf b. Abdullah, Avlonya [bir buçuk akçe ile buyruldu, fî 17 minhu] nakluhu

Kazıyye oldur ki, Karaman'da suğla mahsûlünden emr-i şser̂if mûcebince satun alınan develeri beyân eder

Şütûrân-1 mâde ve ner: 230 mehâr fî 1406 ve 2: 323437

Mâde: 175 mehâr; ner 55 mehâr

be-hesâb-1 katar: 32 katar ve 2 mehâr

Mâde 29 katar, 1 mehâr; ner 9 katar, 1 mehâr

Mevcûd şütürân der-1stabl: 34 katar ve 4 mehâr

Mâde 27 katar; ner 7 katar, 4 mehar

Cem'an, şütûrân-1 mâde ve ner

Mâde katar 56, mehar 1: ner 16 katar, 5 mehâr

[altmış katarı kalıp zâyidi Karacaları ve sakatları ihrâc olunmağın satılmak buyruldu, fî 17 minhu]

Ve atlarda [ve] bârgîrlerde dahi ba'zı sakat olup amele yaramayıp emr-i şerîf olursa anlardan dahi yoklana, amele yaramayan ihrâc ola [bunların sakatları ihrâc olmağın satılmak buyruldu, fi 18 minhu]

(s.15) Saraydârî ve meremmetî-i yaylak-1 Bozdağ der-uhde-i Hacı b. İsmail, fî yevm, 2

Tâlib: Hacı İsmail el-mezbûr

Mezbûr Hacı b. İsmail kadîmü’z-zamândan saraydâr ve meremmetci olup gerü saraydâr ve meremmetçi olmasın ricâ eder [sene 951 Muharreminin gurresinden berü yevmî iki akçe ulûfesi hızâneden verilmek buyruldu, fî 24 Receb 951] nakluhu

Kazıyye oldur ki ağalar oturduğu sundurma içün cedîd ve yüksek yapılsun deyü fermân olunmuş emr-i şerîfiniz ne ise inâyet buyrula [mübârek bayrama dek tamâm olması emr olundu, fî târihin minhu] 
Mevâcib-i Abraham Yahudi, tabîb, fî yevm 20. İki akçe terakki olması fermân olunmuş [iki akçe terakki buyruldu, fî 25 Receb sene 951] naklubu

Şâgirdân-1 ehl-i hiref

Kemâl, şâgird-i ser-zergerân, 1; arabaî-i hassa şud

Tâlib: Memi b. Hızır an-mahrûse-i Bursa [bir akçe ulûfesiyle şâgird buyruldu, fì 25 Receb sene 951] nakluhu

Yusuf b. Abdullah şâgird-i şimşirger. Mezbûr şimşirgerin bir akçe ile bir şâgirdi olup hızmeti kesîr olmağın mezbûr Yusuf'un dahi şâgird olmasın ricâ eder [buyruldu bir akçe ile, fî târihin minhu] nakluhu

Ali, şâgird-i postîndûz, 1. Mezbûrun hızmeti kesîr olup buçuk terakki olmasın ricâ eder [buçuk akçe ziyâde buyruldu, fî târihin minhu] naklubu

Kazzyye oldur ki, matbah-1 âmire içün ihdâs olunan buğday değirmenine buğday pâk edip öğütmeye bir değirmenci lâzım ve ehem olmağın Hamza nâm kimesne bu hızmetin uhdesinden gelir kimesne olup yevmî iki akçe ulûfe ile bir aş ile değirmenci olmasın ricâ eder, emr-i şerîf ne ise inâyet buyrula [buyruldu, fî 9 Şaban sene 951] naklubu

An-cemâ‘at-i gılmân-1 bağçe-i âmire, Davud Vidin, 1

Mezbûr terakki ile külhancı olmasın ricâ eder [buçuk akçe ziyâde ile külhâncı buyruldu, fî 9 minhu] nakluhu

(s.16) Kazıyye oldur ki, Âsitâne-i sa âdete gelen pişkeş meyve ahvâli hâk-i pây-i şerîflerine arz (yırtık)

Kal'aygerî-i evânî-i nühas-1 matbah-1 âmire der-uhde-i Dede Bali ki be-ihtiyâr-hod, fâriğ şud, fî yevm 2

Tâlib: Mustafa, kal'ayger

[iki akçe ulûfe ve bir aşla kalaycı olmak buyruldu, fî 15 Şaban sene 951] naklubu

Kazıyye- $i$ kar [Bozdağ’da görülüp bulunmazsa Bursa'dan gelmek buyruldu] 
Kazıyye oldur ki, muhâsebe hızmetini rûznâmeci bendeniz gözetüp hâliyâ mezbûr rûznâmeci bendenüzün hızmeti kesir olup müstakil bir muhâsebeci lâzım olmağın Sipahi oğlanları kâtibi Hüseyin bendenüz mahal ve münâsib olmağın hâk-i pây-1 şerîfe arz olundu

Mevâcib-i Hüseyin kâtib-i ebnâ-i sipâhiyân, fî yevm 8

[Matbah-1 âmire ve 1stabl-1 âmire ve ihracât-1 hâssa muhâsebelerin görmeği ve üç ayda bir mevâcibât-ı huddâm mukabili yevmî on akçe ulûfe ile muhâsebeci buyruldu, fî 16 Şaban sene 951] naklubu

Kazıyye oldur ki Âsitâne-i saâdette beş akçe ulûfe ile hızmet eden neyzen kulunuza Hazinedârbaşı Mercan Ağa bendenüz matbah-1 âmireden aş olmasın ricâ eder [mezkûra bir aş verilmek buyruldu, fi 16 minhu]

(s.17) Kazıyye oldur ki mahrûse-i İstanbul'da mesâlih-i mîrî gören Hoca Kemal nâm tâcir içün hızmetinden ferâgat eyledi deyü Mehmed Paşa (yırtık) bildirüp öyle olsa mahrûse-i Bursa tâcirlerinden Ali Çelebi b. Mustafa Çelebi mesâlih-i mîrîyi eğer akmişeden ve eğer sâir nesneden her ne ise görmeği iltizâm edüp mezbûrun yerine tâcir olmak ricâ eder [buyruldu, fî 22 Şaban sene 951]

Kitâbet-i cema'at-i ebnâ-i sipahiyân der-uhde-i Hüseyin Çelebi ki muhâsebeî ve mukabeleî şud, fî yevm 8

Tâlib: Osman Çelebi, divitdâr an-ebnâ-i sipahiyân, fî yevm 8.

Mezkûr Osman'a mezbûr kitâbet verilmekiçün emr şerîf vârid olmuştur [Divitdâr Osman'a sipahi oğlanı kitâbeti sekiz akçe ile buyruldu, fî 22 minhu] ta'yîn

Divitdârî der-uhde-i Osman an-ebnâ-i sipahiyân, fî yevm 8

Tâlib: Hüsrev an- ebnâ-i sipahiyân kâtib-i ahkâm, fî yevm 8 [mezkûr Hüsrev kitâbetiyle divitdâr olmak buyruldu, fî 22 minhu]

Kitâbet-i cemâaat-i gurebâ der-uhde-i Hamza b. Ömer kâtib ki müteveffâ şud, fî yevm 6

Tâlib: Yunus b. Şeyh Hasan an-cemâ'at-i gurebâ, fî yevm 6 [ulûfesiyle kâtib olmak buyruldu, fî 6 Ramazan sene 951] naklubu 
Kazzyye-i câmehâ-i Müfti Efendi ve hatîb ve nusûs-gûyen-i büzürg [Mevlânâ Müfti Efendi'ye bir ak sof kaftan çenber atlas sancak ile ve bir ak sof kaftan mevlânâ câmi-i Sultaniye hatîbine îdiyye içün ihzâr oluna deyü buyruldu, fî 13 Ramazan sene 951]

(s.18) Kazıyye oldur ki hâssa atları (yırtık) eden üç nefer yarakçılara emr-i şerîfiniz ne ise inâyet buyrula. Şah Kulu, Bali, Şah Bende (terkin)

Kazıyye oldur ki, merhûm ve mağfûr mevlânâ Yahşi Halife'nin kadîmden hızmetkârı ve emekdârı olan Yusuf içün üç akçe ulûfe ile kapıcı olsun deyü Hüsrev Ağa bendenüz elinden tezkere-i şerîfe vârid olup gerü kapı ağası bendenüz üç akçe ile buyrulmuş imiş dört akçe ile buyurdular deyü haber vermeğin Âsitâne-i hâk-i pây-i şerîfe arz olundu [yevmî dört akçe ulûfe ile kapıcı olmak buyruldu, fî 20 Ramazan sene 951] naklubu

An-cemâ‘at-i bevvâbîn. Yusuf b. Abdullah. 3

Mezbûrun ulûfesine bir akçe terakki olmasın ricâ eder, sâir kapıcılar dörder akçe iledir [bir akçe terakki olmak buyruldu, fî 20 Ramazan sene 951] naklubu

Kazzyye oldur ki, sabıka mahruse-i İstanbul'dan revgan-1 sade getirilmek içün hükm-i şerîf irsal olunmuşdu [doksan iki kantar yă̆ imiş, seksen kantarı mîrî içün ve altı kantar paşa hazretlerine ve altı kantar bu bendelerine ta yîn oluna. Fî 20 Ramazan sene 951]

Kazıyye oldur ki Kuyumcubaşı Mustafa bendenüzün hızmeti kesîr olup matbah-1 âmireden bir aşı olup, kendüye vefâ etmemeğin bir aş dahi ricâ eder [sâbıka bir aşı var imiş bir aş dahi verilmek buyruldu, fi 20 Ramazan sene 951]

Ta âm be-cihet-i hayyâtîn. 20 neferen. Sahan 14. güşt pâre-i küçek, 14. Fodula-i harcî 9 çift [üç aş dahi ta'yîn olundu ki yevmî on aş olur, biri terzibâşı ve kethudâsına ve bölükbaşına, yedisi terzilerine ve mülâzımlarına birer çift fodula buyruldu, fî $27 \mathrm{~N}$ sene 951]

(s.19) Kazıyye oldur ki cihâz mühimmâtıyçün gümrük ve hızâne-i âmireden onbeşbin akçe verilsin deyü fermân olunmuş [içerü Hüsrev Ağaya verilmek buyruldu, fî 11 Şevvâl 951] ta' 'yîn

Be-cihet-i cihâz-1 zevce-i Yahya Bey ağa-yı ebnâ-yı sipâhiyân-1 sa âdet [satun alıp Hüsrev Ağa'ya verilmek buyruldu, fî 11 Şevvâl sene 951] 
Bahâ-i kadife-i çatma-i kırmızı evsat, Bursa, 1 tak, 1205

Bahâ-i kadife-i çatma-i sermâî, evsat, 1 tak, 1105

Bahâ-i kadife-i benek sürh, evsat, Bursa, 1 tak, 655

Bahâ-i kedife-i benek sermâî, edna, 1 tak, 555

Bahâ-i kadife-i benek-i sebz, ednâ, 1 tak, 575

Bahâ-i kadife-i rişte-i Bursa, 2 tak, 704

Bahâ-i kadife-i rişte-i dü-havî, göynek, 2 tak, 545

Bahâ-i kadife göynek, 3 tak, sürh 1, sebz 2, 569

Bahâ-i kadife-i münakkaş-1 Bursa, 1 tak, 665, 1 tak, 565, 1 tak, 565 .

Yekûn 15 tak, sermâye: 7725

Cemâ'at-i tabbâhîn

İbrahim Premedi, fî yevm 4, el-bâki mahlûl 1. An-gılmân-1 kiler-i âmire be- Enderun şud. Fî gurre-i N sene 951, fî yevm 3. ta'yîn

Pervane Bosna, halife-i tabbâhîn, fî yevm 3. Mezbûr İbrahim'in mahlûl kalan bir akçesin kendüye terakki olmasın ricâ eder [bir akçe ziyâde buyruldu mahlûlden, fî 11 Şevvâl sene 951] naklubu

Şâgird Mustafa-i Kastamonu, zerger [yevmî bir akçe ulûfe buyruldu, fi 11 Şevvâl sene 951]

Ferhad, fî yevm 3. Mezbûr akdemden gaybet edüp hâliyâ bulunup gelmişdir, emr-i şerîfiniz ne ise inâyet buyrula, kuyumcubaşı bendenüzün şâgirde ihtiyâcı varmış

Şâgirdân-1 ehl-i hiref, beher nefer, fi 1

(s. 20) An-hızmetkârân-1 solakan, Mustafa b. İbrahim, 1,5. ferâgat kerde Tâlib: Davud Sofya [bir buçuk akçe ulûfe buyruldu, fî 18 Şevvâl sene 951] naklubu

An şâgirdân-1 câmeşûy, Mustafa b. Abdullah, 2, ferâgat kerde Tâlib: Hamza b. Abdullah [iki akçe ulûfe buyruldu, fî 18 Şevval sene 951] naklubu 
Kazıyye oldur ki, sa âdetle mahrûse-i Konya’ya varıldığı zamanda hâssa saraçlar olmağiçün onaltıbin akçeye bir kervansaray satın alınmışdı, hâliyâ paşa hazretlerine ihsân buyrulmuş, mülknâmesin ricâ ederler. [muafnâme verilmek buyruldu, fî $28 \mathrm{~L}$ sene 951]

Kazzyye oldur ki, Âsitâne-i sa âdetde defter emininden sa âdetlü sultanım hazretlerinin havâss-ı humâyûnlarının vilâyet defterinin sûreti ihrâc olunmak lâzımdır, öyle olsa sâbıka olan şehzâdelerden dahi defter ihrâc olundukda mezbûrân defter eminine ve kâtiblerine bir mıkdâr in âm olurmuş, devletlü ve sa âdetlü sultanımın dahi bu husûsda emr-i şerîfleri ne ise inâyet buyrula [defter eminine bir a'lâ döşeme çatma olup kaftan ve kâtiblere bin akçe in'am Çavuş Mustafa ile gönderilmek buyruldu, fî $3 \mathrm{Za}$ sene 951] ta'yîn

Kazıyye oldur ki, Istabl-ı âmire içün iki re’s ester alınıp mezbûr alınan esterlere harbende lâzım olmağın mirâhurbaşı bendenüz mezkûru harbende olmasın ricâ eder

Memi-i Edirne [yevmî beş akçe ulûfe ile harbende olmak buyruldu, yeni kayıtla, fi $3 \mathrm{Za}$ sene 951] nakluhu

(s.21) Kazıyye oldur ki hazret-i pâdişâh-1 âlem-penâh -hullide mülkuhucânibinden şahin getüren kimesnelere emr-i şerîf ne ise inâyet buyrula [Doğancıbaşı Süleyman'a bir münakkaş kaftan ve dokuz nefere altışar yüz akçe verilmek buyruldu, fi 3 Za sene 951]

Bâzdârân 10 neferen

An-cemâ‘at-i bahçe-i âmire

Ahmed Manastır, 1

Mezbûrun kürkçübaşı bendenüz şâgird olmasın ricâ eder [mezkûr Ahmed şâgird verilmek buyruldu, fî 3 Za sene 951] naklubu

An-şâgirdân Mustafa b. Ali, ser-kazzâz

Hüseyin b. Abdullah, 1, mezbûr Hüseyin san'atında tamam mâhir olup ulûfesine terakki olmasın rica eder [buçuk akçe ziyâde olmak buyruldu, fî $10 \mathrm{Za}$ sene 951 ] ta'yîn

Mevâcib-i Mevlâna merhûm Yahşi Halife, fî yevm 70 
Mevlânâ Şems Efendi. Hâliyâ Hoca hazretleri içün emr-i şerîfiniz ne ise inâyet buyrula [yevmî yetmiş akçe ulûfe ta'yîn buyruldu, medrese[ye] gittiğü târihden berü, ve matbah-1 âmireden merhûm Yahşi Halife'ye verdiği aş ve ekmek verile ve bir kile arpa ıstabl-1 âmireden davarlarına verilmek buyruldu, fî 11 Za sene 951] nakluhu

an-matbah-1 âmire, güşt çâryek, 1; ta âm bakraç 4; fodula 7 zevc; fodula-i has zevc

Kazıyye oldur ki divitdâr ile kâğıd emininin zemistânîsi husûsu arz oluna [beşer yüz akçe âdet-i zemistânî verile, amma kimesneden akçe alınmaya deyü buyruldu, fî $24 \mathrm{Za}$ sene minhu] ta yîn

(s.22) Cemâ‘at-i gılmân-1 Enderunî

Yusuf kethudâ-i hızâne-i âmire, fî yevm 3

Yunus, kethudâ-i kilâr-1 âmire, fî yevm 3

Mezbûrlara birer akçe terakki fermân olunmuş emr-i şerîfiniz ne ise inâyet buyrula [birer akçe terakki buyruldu, fì 24 Za sene minhu] naklubu

Kazıyye oldur ki dârüssa âdette olan oğlanlara kitâbet ta lîm eden Kâtib Muhyiddin kendüye dirli[k]cik olmasın ricâ eder [yevmî dört akçe ulûfe buyruldu, fî 24 Za sene 951] ta'yîn

An-cemâ‘at-i şâgirdân-1 tabbâhîn ki mevâcib işân kat' şudend fî 22 Şaban sene 951. ta'yîn

Abdi birâder-i Solak, 1,5. Becâyeş-i Mahmud b. Abdullah, Arnavud [bir buçuk akçe ulûfe buyruldu, fi 24 minhu] nakluhu

Hüseyin b. Abdullah, 1,5. Becâyeş-i Mahmud b. Abdi [kezâlik] naklubu

Hasan birâder-i Hızır, 2. Mezbûrun mevâcibi mahlûl kalır

Ali-i Göllükesri, şâgird-i tabbâh, 2. nakluhu

Mevâcibi kat' olan Hasan birâder-i Hızır'ın mahlûl kalan iki akçesinin bir akçesi kendüye terakki olup üç akçe ile kapıcı olmasın ricâ eder [yevmî üç akçe ulûfe ile kapıcı olmak buyruldu, fî $24 \mathrm{Za}$ sene minhu] 
Kazıyye oldur ki küçük mirâhur bendenüz kara çulda olan has atlardan birkaç tavila at ricâ eder, emr-i şerîfiniz ne ise inâyet buyrula [iki tavila siyah çuldan at verilmek buyruldu, fî 24 minhu]

(s.23) An-cemâ‘at-i seyisân-işân-1 hâssa, seyis-i merhûm Mevlânâ Yahşi Halife Hamza-i Bursa, müteveffa şud, 4

Tâlib: İlyas şâgird-i Mehmed, an-şâgirdân-1 seyisân-işân-1 hâssa, fî̀ yevm 1,5

Mezbûr İlyas gerü Mevlânâ Şems Efendi'nin seyisi olmasın ricâ eder [yevmî dört akçe ulûfe buyruldu, fî 24 minhu] ta yîn

Kazıyye oldur ki, merhûm müteveffâ olan Miralem Hasan Bey'in zimmetinde buğday bahâsindan bin akçe ve mevâcibi kusûrundan ikiyüzon akçe cem'an binikiyüz on akçe olur, emr-i şerîfiniz ne ise inâyet buyrula [eytam[1] olmağın, yetimlerinden alınmasın deyü buyruldu, fi 24 minhu] ta' $y \hat{i} n$

Kazzyye oldur ki, mezbûr cemâ'ate in âm buyrulmuş emr-i şerîf ne ise inâyet buyrula

be-cihet-i cemấat-i solakan, beher nefer fî 100

be-cihet-i cemâatat-i sekbanân, beher nefer fî 50

be-cihet-i cemâ'at-i teberdârân, beher nefer fî 50 [buyruldu, fî $\mathbf{2 4}$ minhu]

Kazıyye oldur ki, hâssa saraçlar cemâatinden Ömer birâder-i Mehmed bir zevc ve çizme (?) diküp mahruse-i Uşak'ta içerüye teslîm eylemiş, hâliyâ ulûfesine bir akçe terakki oluna deyü fermân olunmuş, emr-i şerîf ne ise inâyet buyrula [bir akçe terakki olmak buyruldu, fi 24 minhu] ta' yîn

Mevâcib-i Ömer birâder-i Mehmed an sarracîn-i hâssa, fî yevm 4 Mevâcib-i Mustafa, şâgird-i ser-kazgânî, fî yevm 1

Mezbûr Mustafa san'atında mâhir olup bir zevc kapağıyla bedenli sahan işleyüp Hüsrev Ağa'ya teslîm edüp ulûfesine buçuk terakki olmasın ricâ eder [buçuk ziyâde olmak buyruldu, fî 24 Za sene minhu] ta' yîn 
(s.24) Kitâbet-i cev der-uhde-i Pir Mehmed ki müteveffâ şud, fî 27 Zilkade sene 951 . Fî yevm 4

Tâlib: Piri, an-cemâ'at-i ebnâ-i sipahiyân, fî yevm 8. [yevmî dokuz akçe ulûfe ile arpa kâtibi olmak buyruldu, fî gurre-i Z Sene 951] ta'yîn

Kazıyye oldur ki, hızâne-i âmireden onbin akçe çıkarup içerüye teslîm olunsun deyü buyrulmuş, emr-i şerîfiniz ne ise inâyet buyrula [buyruldu] ta'yîn

Kazıyye oldur ki alem mehterleri cemâ‘atinden Hamza-i zilce-zen birâderi Yahya Pehlivan nakkare-zen olup fenninde tamam mâhir ve san'atına kadir kimesnedir deyü miralem ağa bendeniz ve alem mehterleri başı mezkûru nakkare-zen olmasın ricâ ederler [yevmî beş akçe ulûfe ile nakkare-zen buyruldu, fî $2 \mathrm{Z}$ sene 951] ta yîn

Mevâcib-i nakkare-zen, fî 6

Ve hem alaybeyi bendenüz dîvân-1 âlîye gelüp şöyle arz eylediler ki şimdiki sancağ-1 hümâyûndan mâadâ bir sancak başı dahi işlensün ki sefer-i hümâyûn vâki' oldukda hâzır buluna [bir alembaşı ta'yinâtıyla ihzâr olmak buyruldu, fî 2 minhu]

Kazıyye oldur ki hazînedârbaşı kulunuz sarayda in'amiçün ikişer bin akçe alurlar, şimdiye değin üç def a ikişer bin akçe verildi [her ay ikişer bin akçe verilmek buyruldu, fî 2 minhu]

Kazıyye oldur ki, büyük mirâhur bendenüzün yevmî iki keyl yemi olup küçük mirâhur bendenüz dahi inâyet umar [bir kile arpa buyruldu, fi 16 Zilhicce sene 951]

Kazayye oldur ki has ahur kethudâsının yevmî iki yemi olup, bârgir ahuru kethudâsı dahi, inâyet umar, hâdisdir [bir keyl arpa buyruldu, fi 16 minhu]

(s.25) Kazıyye-i Yaylak-1 Bozdağ [Birgi kadısına ve eminine hüküm yazılıp teftiş oluna]

An-gilmân-1 pişkeş ki an-Ulama Bey âmed ve be-ehl-i hiref şâgird dâdend

İskender Bosna, be-şimşirger

Hüseyin Bosna, be-zerger 
Şaban Bosna, be-mataracı

Süleyman Bosna, be-zerkülah-dûz

Ferhad Bosna, be-uncu [birer buçuk akçe ulûfe buyruldu, fî $16 \mathrm{Z}$ sene 951] ta yîn

Kazıyye oldur ki, Âsitâne-i sa âdetten gelen arabacılar husûsunda emr-i şerîfiniz ne ise inâyet buyrula [günde bir kirde et verile, kendüler ala (?), fî 16 minhu]

Kazıyye oldur ki, çadır mehterleri cemâ'atinden sâbıka zemistânî verildi ise gerü verile deyü fermân olunmuş, sâbıka bir kere yüzer akçe câme bahâ verilüp hâliyâ ulûfeleri birer akçe ziyâde olup ol ziyâde ana bedel olmuştur, sâbıka gelen şehzâdeler âsitânelerinde mehterleri ikişer akçe ulûfe ile olmuştur, emr-i şerîfiniz ne ise inâyet buyrula

Kazıyye oldur ki Mahmud nâm kimesne sâbıka Soğucakkoru nâm koruya korucu olup geçen yıl ve hem bu yıl koruya sâbıkda gelen şehzâdelerden dört akçe ulûfem var idi deyü cevâb edüp amma elinde berâtı olmayıp hâliyâ iki akçe ulûfe ile korucu olmasın ricâ eder [yevmî iki akçe ulûfe ile korucu olmak buyruldu, fî 22 Muharrem sene 952] ta'yîn

Kazıyye oldur ki küçük mirâhur bendenüzün saraçlarına bir saraçhâne lâzım olmağın hâk-i pây-1 şerîfe arz olundu [saraçhâne işlenmek buyruldu, fî 22 Muharrem sene 952]

(s.26) Kazıyye oldur ki cihâz içün beş bin nakd akçe ve bir kıt'a kırmızı frengi atlas [ve] dört kıt'a çatma ve üç kıt'a münakkaş ve beş kıt'a eyinlik kadife fermân olunmuş, emr ne ise inâyet buyrula [verilmek buyruldu, fi 22 Muharrem sene 952]

Kazıyye oldur ki, çadır mehterleri cemâ‘atinden bölüğe çıkanlara kanunmuş ki küreden(?) bir bârgir verilirmiş, hâliyâ çadır mehterler bölükbaşılığından ulûfeciler zümresine ihrâc olunan Murad kendüye bir bârgir sadaka olunmasın ricâ eder [bir bârgir verilmek buyruldu, fi 23 minhu]

Kazıyye oldur ki 1stabl-1 âmire önünde olan meydan içün hemvâr ola deyü buyrulmuş, emr-i şerîfiniz ne ise buyrula [yaylak vaktinde görüle deyü buyruldu] 
İnâm-1 hazret-i pâdişâh-1 âlem-penâh [arz olundu]

Gılmanân: neferen 3

Minhâ: İnâm be-ağayân-1 Enderunî, neferen 4; müteveffâ, nefer 1 be-Hüseyin Ağa, ağa-yı der, 1 nefer; be-Mercan Ağa, ser-hâzin, nefer 1; be-Hüsrev Ağa, ağa-yı dârüssa âde, 1 nefer; be-Murad Ağa, ser-kilâri, nefer 1

be- cemâ‘ât-i ehl-i hıref, şâgird dâdend: be-hayyâtîn neferen 4; be-kazzâz, 1 nefer; be-mücellid, 1 nefer; be-savâniyân 1 nefer. Yekûn neferen 7

El-bâki be-cihet-i Enderun, neferen 18. be-hızâne-i âmire nihâdend, neferen 5; be-kilâr-1 âmire, neferen 3; be-oda-i küçek, neferen 10

Mevâcib-i Mevlânâ Muhyiddin hattat-1 mu'allim-i gılmân-1 Enderunî, fî yevm, 4. Sâbıka kâtib olup ferâgat eden Sinan'ın mevâcibinden bir akçe terakki olmasın ricâ eder [Kâtib Sinan'in ulûfesi inkıtâ' yazılıp ulûfesinden Mevlânâ Muhyiddin'e iki akçe terakki buyruldu, fî 23 minhu] ta'yîn

(s. 27) Kazıyye oldur ki dergâh-1 âlîden gelen bevvâblara yirmibeş filori ki iki keseye üç bin olur ve Âsitâne-i sa âdetten dergâh-1 âlîye giden bevvâblara beşer yüz akçe verilir imiş, bu bâbda emr-i şerîfiniz ne ise inâyet buyrula

Mevâcib-i Yusuf râh-âbî, fî yevm 2. Mezbûr Yusuf'un mevâcibi kıllet ve hızmeti kesîr olup ulûfesine bir akçe terakki olmasın ricâ eder [bir akçe ulûfesi terakki buyruldu, fî-sâdis-i Safer sene 952] ta yîn

Mevâcib-i Mehmed b. Abdullah şâgird-i mâstger ki müteveffâ şud, fî yevm 1,5 ta'yîn

Tâlib: Yusuf b. Abdullah [bir buçuk akçe ulûfe ile şâgird olmak buyruldu, fì $\mathbf{6}$ minhu] ta'yîn

Mevâcib-i Bayezid b. Abdullah şâgird-i sebzeî, fî yevm 1. Mezbûrun mevâcibine bir akçe terakki olmasın ricâ eder [buçuk akçe ziyâde buyruldu, fî 6 minhu] 
Kazıyye oldur ki hâssa atlar içün otuzbeş şereke ve iki katar katıra ve beş katar deveye raht şereki taleb ederler, emr ne ise inâyet buyrula [otuzbeş şereki elli olmak bakisi ber-karar olmak buyruldu, fî 6 minhu]

(s.28) Kazıyye oldur ki mehterler cemâ'atinden ulûfeciler zümresine ilhâk olunan Murad nâm kimesne tirkeş bahâ taleb eder emr-i şerîfiniz ne ise inâyet buyrula [hemân içerüden çıkan gılmana verilmek âdet ola deyü buyruldu, fî 13 Safer 952]

Kazıyye oldur ki matbah-1 âmirede vekîl-harc olan Yahya b. Veli'nin hızmetinde ihmâl ve müsâhelesi olmağın silahdarlar cemâ‘âtinden altı akçe ulûfeye mutasarrıf olan Arab Hasan mahal ve münâsib olup ve mezbûr hızmetin tamâm uhdesinden gelir kimesne olmağın hâk-i pây-1 şerîfe arz olundu [mezkûr Yahya ulûfesiyle silahdar olmak buyruldu ve yerine mezkûr Hasan yevmî yedi akçe ulûfe ile vekil-harc olmak buyruldu, fî 13 minhu] ta'yîn

Mevâcib-i Derviş, kethudâ-i teberdârân ki be-cemâ‘at-i çavuşân fermûde, fi yevm 4. ta'yin

Tâlib: Firuz, Hersek an-teberdârân, fî yevm 3 [yevmî dört akçe ulûfe ile kethudâ-i teberdârân olmak buyruldu, fî 13 minhu] ta yîn Tâlib: becây-1 Firuz

Mezbûr Firuz’un gedüğüne kapıcılar cemấati kâtibi olan Hamza’nın birâderi Kurd teberdâr olmasın ricâ eder [mezkûr Firuz yerine üç akçe ile teberdâr buyruldu, fî 13 minhu] ta'yîn

Mevâcib-i Oruç birâder-i Nasuh an-bevvâbîn ki müteveffâ şud, fî̀ yevm 4

Tâlib: Hüseyin birâder-i Süleyman an-şâgirdân-1 tabbâhîn, fî yevm 2 [yevmî dört akçe ile bevvâb olmak buyruldu, fî 13 minhu]

Mevâcib-i Yusuf cüllâh, fî yevm 3

Mezbûr Yusuf ulûfesine bir akçe terakki olmasın ricâ eder [bir akçe ulûfesine ziyâde olmak buyruldu, fî 13 minhu] ta'yîn 
An-şâgirdân-1 câmeşûyân ki gaybet kerdend

Hüseyin, 1,5

Hamza, 2

Tâlib: Yusuf becây-1 Hüseyin [bir buçuk akçe ulûfe ile buyruldu, fî 20 Safer sene 952] ta'yîn

Mehmed b. Abdullah, becây-1 Hamza [iki akçe ulûfe ile buyruldu, fî 20 Safer sene 952]

Asıl sarracîn-i hâssa neferen 44, şâgirdân neferen 20: yekûn 64 . be-cihet-i mühimmât-1 mirâhur-1 büzürg be-cihet-i esbân-1 hazret-i mîr -tâle bekahu-, neferen 7, fî 2; neferen 14

be-cihet-i esbân-1 Ağa-i Derviş Dede ve ser-kiler, neferen 3, fî 1 ; neferen 3

be-cihet-i esbân-1 silahdâr ve çukadâr ve irkebdâr, neferen 3, fî 1 ; neferen 3

be-cihet-i esbân-1 Mevlânâ Şemseddin Hoca, nefer 1 be-cihet-i esbân-1 mirâhur ma'a veledeş, neferen 4 be-cihet-i hızmet-i anbâr-1 cev, nefer 1 be-cihet-i hazîne-i sarracân, 1 nefer be-cihet-i âvurden-i cev ve kiyâh ve kâh, neferen 5 be-cihet-i kethudâ-i Istabl-1 âmire, 1 nefer, veledeş Yekûn: neferen 33, an-şâgirdân neferen 17; yekûn neferen 50

El-bâki neferen 11, an-şâgirdân neferen 3; yekûn neferen 14

Be-cihet-i mühimmât-1 mirâhur-1 küçek be-cihet-i esbân-1 Hüsrev Ağga an-dârüssa'âde, 1 nefer, (kadîm) be-cihet-i gilmân, der-dârüssa'âde-i enderunî neferen 6 beher 2 neferen, fi 1 , neferen 2 (kadîm) be-cihet-i gilmân der-dârüssa âde-i birunî, neferen 4, beher 2 neferen fî 1 , neferen 2 (kadîm) 
be-cihet-i gilmân-1 enderunî, neferen 120, bâ-tahmîn, beher 5 neferen, fî 1, neferen 24, kezâlik neferen 18 (hâdis)

be-cihet-i esbân-1 bazdarân an-gılmân-1 hâssa, neferen 4, beher 2 neferen, fî 1, neferen 2: der-nezd-i hazret-i mîr tâle bekahu, neferân 1 nefer; der-nezd-i hazret-i paşa -dâmet maâlihu-, neferân 1 nefer (kadîm)

be-cihet-i âvurden-i cev ve kiyâh ve kâh, neferen 2 (kadîm) be-cihet-i kâtib, nefer 1 (hâdis)

be-cihet-i mirâhur, neferen 2 (kadîm)

Yekûn: neferen 30; an-kadîm neferen 11; lâzım olan neferen 19 (s. 30) Lâzım olan on dokuz nefer saraçlar içün bedel bunlardır ki zikrolunur. tácyîn

an-cemâ'at-i arabaciyân-1 hâssa

Bekir birâder-i Kul, 3,5

Hacı Mehmed, Mora 3

Hasan b. Sadık, 3

Kemal b. Hacı Mustafa, 3. an-cemâ'at-i seyisân

Turgud birâder-i Davud, 4

Yekûn neferen 4, fî yevm 12,5

an-cemấat-i sakayân

Hüseyin Arnavut, 4

an-şâgirdân-1 sarracân

Hüsrev b. Abdullah, 1

Yekûn: neferen 7

Yeni ulûfe ile yazılacak on iki nefer bunlardır ki zikrolunur. ta'yîn Hasan b. Mustafa; Hasan b. Abdullah; Ali b. Devlet; Ali-i Engürî; Ali b. Kul; Ali b. Ahmed; Hüseyin b. Ali; Hamza b. Ali; 
Hasan b. İbrahim*; Emirze b. Yusuf: Bali birâder-i Süleyman Çelebi; Hasan Yitik**. Yekûn: neferen 12, fî 3: 36

Mahlûl şâgirdân-1 sarracân tá yîn

Ahmed birâder-i Behram Çavuş. Becây-1 Hüsrev b. Abdullah ki şâgird ki sarac şud. Derviş b. Murad, ibtida; Veli b. Abdullah, ibtida

Yekûn neferen 3, fî 1: 3

an-cemâ'at-i arabaciyan ma'a şâgirdân: neferen 44

Ser-bölükân: Mustafa birader-i Kul, 5 [bir akçe ziyâde buyruldu]; Hacı İvaz b. Ali, 5,5 [bir akçe ziyâde buyruldu, fî 27 sene minhu]

Naccarân-1 arabahâ-i hâssa: Mehmed Konya, 3; Hasan b. Abdullah, 4; Mustafa naccâr.

Haddâdân: Muharrem b. İshak, 3

be-cemâ'at-i sarracân-1 raht: neferen 4

Sarrac-1 arabaciyân: Mehmed b. Mustafa, 3

Fî yevm 12,5: yekûn neferen 11

El-bâki neferen 33

(s.31) Hâliyâ yirmi araba olup her arabaya ikişer neferden kırk nefer ve beş nefer dahi ziyâde hastaları içün ve gayri içün ve dört nefer aşçı ve saka şâgird dahi lâzım olup cümle kırk dokuz nefer kimesne mirahur ağa bendenüz lâzımdır demeğin otuz üç nefer mevcûdumuz olup bâki on altı nefer arabacı dahi lâzım geldi. [buyruldu, fî 27 minhu] ta'yîn

Rıdvan b. Abdullah; Hamza b. Abdullah, tâbi'-i Hoca; Mehmed b. Abdullah; Hüsrev b. Abdullah; Mustafa b. Abdullah; Piri b. Abdullah: Nasuh b. Saraydar; Mehmed b. İsa; Yahşi şâgird-i İvaz; Kasım b. Abdullah; Hasan b Mahmud; Pir Hasan b. Şeyh Hasan;

* “Terkin” kaydı düşülerek Osman b. Emirhan isminin yerine Hasan b. İbrahim yazılmıştır.

** “Terkin” kaydı düşülerek Nasuh b. Hüseyin isminin yerine Hasan Yitik yazılmıştır. 
Mahmud b. Abdullah; Mehmed b. Hayreddin; Abdi b. Ali; Veli b. Ayas*

Yekûn: neferen 16, fî 2: 32

Hâssa dörtyüz bârgirlerin üç nefer nalbandı olup bir nalband dahi lâzımdır ta'yîn

Hüseyin b. Hamza, 3

Kazıyye oldur ki, hâliyâ alınan esterlere dahi harbende ve nalband lâzım olmağın mirâhur ağa bendenüz mezkûrları harbende olmasın ricâ eder

Cemâ'at-i harbendegân: Seydi-i Karamanî; İskender Trabzon; Mehmed Yanbolu [beş akçe ulûfe ile buyruldu fî 27 minhu]

Cümle katırlarun bir nalbandı olup vefa eylemez deyü bir nalband dahi rica ederler; Ali-i Azizlü, nalband (terkin)

Kazıyye oldur ki aşçı şâgirdlerinden kimi girihte ve kimi saka ve kimi bevvâb olup gedüklerine birer kimesne dahi lâzım olmağın mezbûrların kilârbaşı kulunuz şâgird olmasın ricâ eder [beş nefere ikişer akçe ulûfe buyruldu, fî $27 \mathrm{minhu}$ ] $t a$ ŷ̀n

Mehmed b. Abdullah, becây-1 Mustafa birâder-i Yakub ki saka şud; Yusuf b. Abdullah, becây-1 Hüseyin birâder-i Hızır ki kat şud; Hasan b. Abdullah, becây-1 Ali b. Göllükesri ki bevvâb şud; Mahmud b. Abdullah, becây-1 Hüseyin b. Abdullah ki bevvâb şud; Süleyman b. Yusuf, becây-1 Mehmed b. Abdullah ki girihte şud; Mehmed birâder-i Kul, ibtidâ (terkin)

(s.32) Kazıyye oldur ki, çadır mehterleri cemâ‘ati cem'an elli dört nefer olup mehterbaşı bendeniz hızmetleri ağırdır bu mikdâr ademle kifâyet etmez dahi âdem gerekdir demeğin hâk-i pây-i şerîfe arz olundu [altı nefer dahi ziyâde buyruldu, fî 27 Safer sene 952] ta' yîn

Kazıyye oldur ki mehterler cemấatinden Murad nâm kimesne bölüğe çıkıp yerine Behram nâm kimesne mehter olmak ricâ eder emr-i şerîf neyse inâyet buyrula [bir akçe bölükbaşıllk buyruldu, fî 27 minhu] ta'yîn

* “Terkin” kaydı düşülerek Hasan Yitik isminin yerine Veli b. Ayas yazılmıştır. 
Mevâcib-i Murad ki be-bölük ilhâk şud, fî yevm 5

Mevâcib-i Behram, fî yevm 4

Kazıyye oldur ki, hastalara timar eden Mezid nâm kimesnenin üç akçe vazîfesi olup vazîfesi harcına ve cihet-i ma'işetine vefâ eylemediği sebebden terakki ricâ eder emr-i şerîf ne ise inâyet buyrula [bir akçe ziyâde buyruldu, fi 27 minhu]

Kazıyye oldur ki beş nefer divân sakaları olup sakabaşı bendenüz hızmetleri ağırdır bu mikdâr âdemle kifâyet etmez bir kimesne dahi lâzımdır dediği hâk-i pây-i şerîfe arz olunur emr-i şerîf neyse inâyet buyrula [üç akçe ulûfe ile buyruldu] ta'yîn

Mesih birâder-i Mehmed b. Mahmud, 3.

Kazıyye oldur ki, yeniden alınan katırları beyân eder

an-kaza-i Demirci an-yed-i Kurd ve Hacı Abdi, 20 re’s, 19060

an-kaza-i Adala, an-yed-i Ebulmüslim b. Alem, 5 re’s: 4480

an-kaza-i Lazkiye, 5 re’s: 4800

Yekûn: 30 re’s: 28340 (beher fî 944)

Cem'an atîk ve cedîd yüz re’s katır olup harbendemiz vefâ eylemez üç nefer harbende ve bir nefer nalband ve beş nefer şâgird lâzımdır deyü mirâhurbaşı bendenüz arz eder

Lâzım olan harbende bunlardır: Mehmed Amasya; Hızır Üzeyirlü, Ali Üzeyirlü [beş akçe üç harbendeye ulûfe buyruldu, fî 12 Ra sene 952] ta'yîn

Nalband, Ali Üzeyirlü [üç akçe ulûfe ile na'âl buyruldu] ta'yîn Şâgirdân: neferen 10 [üç nefer şâgird buyruldu, fî yevm 3] ta'yîn

(s.33) Kazıyye oldur ki dârüssa âdede cevârîden on nefer kimesneye birer akçe terakki fermân olunmuş [birer akçe on nefere terakki buyruldu, fi 12 Ra sene 952] ta'yîn

Kazıyye oldur ki kazzâzbaşının hızmeti kesîr olup bir şâgird dahi taleb eylemeğin Hasan b. Abdullah mahal ve münâsibdir deyü kazzâzbaşı kulunuz arz eder [bir akçe ulûfe buyruldu] ta'yîn 
Kazıyye oldur ki, cemâ‘at-i hayyâtînden mezkûrların ulûfesi kalîl olmağın terakki ricâ ederler [birer akçe ulûfeleri ziyâde buyruldu, fi $24 \mathbf{R}$ sene 952] ta'yîn

Şehsuvar b. Şüca Paşa, 3; Ali Arnavud, 3; Mustafa Arnavud birâder-i Kul, 3; Ahmed b. Mustafa, 3; Pervane ütüger 3

(s. 34) Kazıyye oldur ki çadır mehterleri cemâ‘ati cem'an elli dört nefer olup mehterbaşı bendenüz hızmetleri ağırdır, bu mikdâr âdemle kifâyet etmez, dahi adem gerekdir demeğin hâk-i pây-i şerîfe arz olundu (terkin)

Kazıyye oldur ki yirmi nefer solak ve altı nefer hızmetkâr bendelerinüz Âsitâne-i sa âdete gelüp şöyle arz eylediler ki dergâh-1 âlîde olan solaklara her senede otuzar akçe kemân bahâ verilir kanundur ve sâir şehzâdeler kapısında verile gelmiştir deyü taleb eyledikleri ecilden hâk-i pây-i kimyâ-tâbınıza arz olundu [otuzar akçe âdet-i kemân bahâ buyruldu, fî $24 \mathrm{R}$ sene 952] ta'yîn

Kazıyye oldur ki hâssa arabacılar cemâ‘atinden ba'zı müteveffâ olup ve ba'zı ferâgat edip gediklerine birer kimesne dahi lâzım ve ehemm olmağın mezkûrlar ta'yîn olundu [yevmî ikişer akçe ulûfe ile altı nefer kimesne arabacilara buyruldu, fî târihin minhu] ta yîn

Hüseyin Mora, fî yevm 4, müteveffâ şud ve becâyeş-i Abdi b. Ali

Piri b. Abdullah, fî yevm 3, sarac şud ve becâyeş-i Mustafa b. Hüseyin

Ali-i Niş, fî yevm 3, gaybet kerde ve becâyeş-i Emirze birâder-i $\mathrm{Kul}$

Mustafa-i Bosna, fî yevm, 3, müteveffâ şud ve becâyeş-i Yusuf Üsküdar

Veli b. Ayas, fî yevm 3, gaybet kerde ve becâyeş-i Hasan

Hüseyin b. Mustafa, an-cemâ‘at-i nalbandân, fî yevm 4, sarac şud ve becâyeş-i Yusuf Güzelhisar [naâl üç akçe ulûfe ile buyruldu, fî târihin minhu] ta'yîn

Mezbûrlar evce (?) eder ki hızmet ederler

Kazıyye oldur ki merhûm Kapıcıbaşı Rıdvan Ağa kulunuzun muhallefatından alınan gulamlardır ki mezbûrlar şâgirdliğe verilmiştir [üç nefer gulama birer akçe ulûfe buyruldu, fî 24 minhu] ta $y \hat{i n n}$ 
Yusuf Bosna, 1, be-Memi an-mataraî an-sarrâcîn-i hâssa-dâde

Murad Bosna, 1, be-Hayreddin eyerci-dâde

Behram Bosna, 1, be-Hasan nakkaş-dâde

An-cemâ'at-i nalbandân-1 hâssa [üç akçe ulûfe ile naâl olmak buyruldu, fî târihin minhu]

Mehmed b. Ömer, 3, kat'şud becâyeş-i Hızır Elbasan

Kazıyye oldur ki Âsitâne-i sa âdetten gulâmlar getüren çavuşa câmeden gayrı bir mıkdâr nakdiye verilmek câiz midir, emr-i şerîfiniz ne ise inâyet buyrula (terkin)

(s. 2)*

Defter-i tezkire-i arz el-vâki' fî gurre-i Ca sene 952

Cemâ'at-i kâtibân-1 hizâne-i âmire ta'yîn

İbrahim, rûznâmçeî, 20 [yevmî dört akçe ziyâde buyruldu,fî gurre-i Ca sene 952]

Kurd, mukata'â̂, 15 [iki akçe ziyâde buyruldu, fî târihin m.]

Süleyman, tezkireî, 10 [iki akçe ziyâde buyruldu, fî-târih]

Mezbûr bendelerinüzün hızmeti kesîr olup bir vechile müstahıkk-1 inâyet olan bendelerünüzden olup hâliyâ hâk-i pây-i sa âdet-bahşda terakki olmasın ricâ ederler

Kazıyye oldur ki Âsitâne-i sa âdetten gulâmlar getüren çavuşa câizeden gayri bir mıkdâr nafaka verilmek câiz midir emr-i şerîfiniz ne ise inâyet buyrula [iki bin akçe harçlık buyruldu] ta'yîn

Kazıyye oldur ki Mehmed nâm kimesne üç yıldan berü tezkire şâkirdliğine hızmet edüp emekdâr ve maslahat-güzâr olup hâliyâ hayme mehterlerine ve sekbânlara ve solaklara ve cemấat-i ehl-i hırefe müstakil kâtib lâzım olmağın hâk-i pây-i saâdet-bahşdan inâyet ricâ eder (terkin)

Kazıyye oldur ki, hâssa atların otları kifâyet etmeyüp Manisa'ya gönderilmek husûsunda emr-i şerîf ne ise inâyet buyrula [Manisa cânibine gönderilmek buyruldu, fì 8 sene 952] naklubu

* Orijinal defterdeki sonradan verilen yanlış sayfa numarası olup burada ilgili yere eklendi. 
Kazıyye oldur ki, solaklar kethudâsının yoldaşları ile kadîmden bir sofra ta âmı olup şimdilik verilmeyüp hâliyâ ricâ ederler emr-i şerîf ne ise inâyet buyrula [solaklar kethudâlarına bir sofra ta âm buyruldu, fi 8 minhu]

(s.35) Cemâ'at-i matbah-1 âmire

Mezkûrların ba'zısının birer ve ba'zısının birer buçuk akçe ulûfeleri olup buçukar akçe terakki ricâ ederler: neferen 35; izdiyâd an-hızâne-i âmire 18 [otuz altı nefer şâgirdlere buçukar akçe ziyâde buyruldu, fi 8 Ca sene 952] ta'yîn

Şâgirdân-1 kiler ve gayrıhu

Hasan b. Abdullah, 1,5 mezbûr bir akçe terakki inâyet umar; Ahmed b. Abdullah, 1,5; Mustafa b. Abdullah, 1,5; İbrahim b. Abdullah, 1,5; Hasan b. Abdullah-1 diğer, 1,5; Yusuf b. Abdullah, 1,5 şâgird-i mâkiyânî; Bayezid b. Abdullah, 1,5 şâgird-i sebzeî; Karagöz b. Abdullah, 1,5 şâgird-i mâkiyânî; Yusuf b. Abdullah, 1,5 şâgird-i mâstger; Yusuf b. Abdullah-1 diğer, 1 şâgird-i şem'ger

Cemâ‘at-i kiler

Hasan b. Abdullah, 1,5 müteveffâ şud; Nasuh b. Abdullah, 1, becây-1 Hasan, an-mahlûl Hasan b. Abdullah ki müteveffâ şud; Ahmed b. Abdullah, 1 an-mahlûl Hasan b. Abdullah, müteveffâ şud, 0,5 an-hızâne-i âmire, 0,5 becây-1 Hasan

Cemâ‘at-i şâgirdân-1 tabbâhîn

Piri b. Abdullah, 1,5; Yahşi b. Abdullah, 1,5; Mehmed b. Abdullah, 1,5; Mehmed b. Abdullah, 1,5; Behram b. Abdullah, 1,5; Mehmed b. Abdullah, 1,5; Veli b. Abdullah, 1,5; Yusuf b. Abdullah, 1,5; Mahmud b. Abdullah, 1,5

Cemâ'at-i helvaciyân

Mustafa b. Abdullah, 1,5; Hamza b.Abdullah, 1,5; İskender b. Abdullah, 1,5; Hızır b. Abdullah, 1,5; Hüseyin b. Abdullah, 1,5; Mustafa b. Abdullah, 1,5; Sefer b. Abdullah, 1,5

An-cemâ'at-i habbâzîn [buyruldu, fî 8 Ca sene 952] 
Süleyman Serfice, 4, müteveffâ şud; Abdi Halife, 4, becây-1 Süleyman üstâd şud; Mehmed Halife, 2 ziyâde 1, becây-1 Abdi Halife şud; Ali b. Abdullah, becây-1 Mehmed Halife şud, anmahlûl Abdi Halife, 2 ziyâde 1, an-mahlûl-i Abdi.

An-cemâ‘at-i şâgird-i habbâzîn

Mustafa b. Abdullah, 1,5; Pervane b. Abdullah,1,5; Mahmud b. Abdullah, 1,5; Ahmed b. Abdullah, 1,5; Turhan b. Abdullah, 1,5; Yusuf b. Abdullah, 1,5; Mehmed b. Abdullah, 1,5; Mustafa b. Abdullah, 1,5.

(s.36) Kazıyye bu bendelerine mukaddem Manisa'ya gitmek buyrulmuş emir nedir [cemaziyelevvelin yirmisinde Manisa'ya gidilmek buyruldu, $f i$ 8 Ca sene 952] ta'yîn

Mevâcib-i Abdi, mu'allim-i esbân-1 hâssa, fî yevm 0,5; mezbûra bir akçe terakki buyrulmuş emr-i şerîf ne ise inâyet buyrula [ziyâde bir akçe ulûfe buyruldu, fî 8 minhu]

Kazıyye tâcir Ali Çelebi'nin Bursa'da alınan avârız ecr içün hükm-i şerîf inâyet umar [Rüstem Paşa Hazretleri'ne mektûb-1 şerîf verilmek buyruldu]

İn âm-1 hazret-i pâdişah-1 âlem-penâh -hullide hilâfetuhu-: neferen 12 ta'yîn

Minhâ: in âm neferen 2

Der-oda-i küçek nihâde: neferen 5. Haydar, Karagöz, İsfendiyar, İdris, Muzaffer

Be-cemâ'at-i teberdarân fermûde: Hasan Çerkes, Hüseyin Çerkes, Ferruh Çerkes, Hürrem Çerkes [yevmî üçer akçe ulûfe ile teberdâr buyruldu, fî gurre-i Ca sene 952]

Be- müntakil-dâde, 1 nefer, be ser-mûzedûz, fî yevm 1: fî 15 Ca sene 952. ta'yîn

Kazıyye oldur ki Saray-1 âmirede emr olunan binâyı beyân eder [bu zikrolan husûslar bu bendeleri varınca yapılmak buyruldu, fî 15 minhu] ta'yîn

Küçük odanın vâsi' olması

ve Saray-ı âmirenin orta kapısı yapılıp üzerine bir kasr olmak 
ve Istabl-1 âmire kurbunda olan hâlî yere havlu olmak

ve sekbanlar odası yapılmak*

Mehterhâne yapılmak [buyruldu]

(s.37) Mevâcib-i Mustafa b. Hasan neyzen, fî yevm 5. Mezbûra bir akçe terakki fermân olunmuş [bir akça ziyâde buyruldu, fî 15 Ca sene 952] ta'yîn

Kazzyye oldur ki neyzen Mustafa'ya bâride olan Miskalî Hüseyin'e dört akçe ulûfe fermân olunmuş emr-i şerîfiniz ne ise inâyet buyrula [dört akçe ulûfe buyruldu, fî 15 minhu]

Kitâbet-i cemâ'at-i silahdarân der-uhde-i Ali, fî yevm, 7 . Mezbûrun ağasıyla zindegânesi olmayup ve hem ehl-i kalem olmamağın ağası bir ahar kâtib ricâ eder. Tâlib: Yahya b. Veli, an-silahdarân, vekiliharc-1 sâbık, fî yevm 7 [vekiliharc Yahya'ya ulûfesiyle silahdar olmak buyruldu, fî 15 Ca sene 952]

Mevâcib-i Ali şâgird-i mukata'â̂, fî yevm 7. Mezbûr Ali maslahatgüzâr ve ehl-i kalem ve uslûb-1 defterin tamâm uhdesinden gelir kimesne olup ve mukata'anın ekser hızmetin mezkûr görüp hâk-i pay-i sa âdetlerinden ulûfesine bir akçe terakki olmasın ricâ eder [bir akçe ulûfesi ziyâde olmak buyruldu, fî 15 Ca sene 952] ta yîn

Kazıyye-i buçuk-1 emirhorân, fî yevm, 3 [bir akçe dahi ziyâde buyrulup her ağaya ikişer akçe bozula, buçuk emr olundu, fì 15 Ca sene 952] ta'yîn

Kazıyye oldur ki Ferhad nâm kimesne divân-1 âlîde ve dergâh-1 âlîde hızmetkâr olup bir akçe ulûfe ile cellad şâgirdi olmak ricâ eder [bir akçe şâgird ulûfesi buyruldu, fî 15 Ca sene 952] ta'yîn

Kazıyye oldur ki Hızır b. Bahşayiş nâm kimesne kadîmü'z-zamândan bir akçe ulûfe ile Gölcük saraydârı imiş, hâliyâ gerü bir akçe ulûfe ile saraydâr olmasın ricâ eder [bir akçe ulûfe ile saraydâr buyruldu, fi 15 Ca sene 952] ta'yîn

(s.38) Kazıyye oldur ki hâssa arabacılar cemâ'atinden ba'zı ferâgat edip gediklerine birer kimesne dahi lâzım ve ehemm olmağın mezkûrlar ta'yîn

* Bu kaydın üzeri çizilmiştir. 
olundu [bu iki nefer kimesne ikişer akçe ulûfe ile arabacı olmak buyruldu, fî 15 Ca sene 952] ta' yîn

Yusuf Trabzonî, 3. Gaybet kerd becâyeş-i Muzaffer b. Ali

Abdi b. Ali, 2. Gaybet kerd becâyeş-i Hasan Arnavud

Paşa hazretleri -dâmet-ma'âlibu-arz ettiği kazâyâ bunlardor ki zikrolunur

Mevâcib-i Musluhiddin cerrâh, fî yevm 5. Mezkûra iki akçe terakki fermân olunmuş emr-i şerîfiniz ne ise inâyet buyrula [buyruldu, fî 22 Cemaziyelevvel sene 952] ta yîn

Mevacib-i Hasan kehhâl, fî yevm, 9. Mezbûr kehhâle bir akçe terakki fermân olunmuş emr-i şerîfiniz ne ise inâyet buyrula [buyruldu, fî 22 Cemaziyelevvel sene 952] ta'yîn

Kazıyye oldur ki pehlivanların duâcısı olan Hızır b. Abdullah nâm kimesneye günde iki akçe ulûfe fermân olunmuş emr-i şerîfiniz ne ise inâyet buyrula [buyruldu, fi 22 Cemaziyelevvel sene 952] ta'yîn

Kazıyye oldur ki dergâh-1 âlîde sekbanların otuzar kemân bahâ verilmek kanunları olmağın bunlar dahi ricâ ederler emr-i şerîf ne ise inâyet buyrula [buyruldu, fi 22 Cemaziyelevvel sene 952] ta'yîn

(s.39) Kazıyye oldur ki devlet ü sa âdetle yaylaka müteveccih olundukda hızâne-i âmire ile hazîne oğlanları ve küçük oda oğlanları mukaddem irsâl olunmuşlaridi, hâliyâ gerü üslûb-ı sâbık üzere gönderilmek câiz görülmeğin hâk-i pây-i sa âdet-bahşa arz olundu.

Hâliyâ Birgi kadısı olan Muhyiddin duâgûylarının pişkeşidir

Mahal (?) katır, 1 re's; destâr-1 Kandeharî, 2 kıt'a; sereng-i Bursa, 2 tâk; kemha-i Bursa, 2 tâk; kutnu-i Bursa, 2 tâk.

Mahrûse-i Tire'de Lütfi Paşa Medresesi müderrisi olan Mevlânâ Cafer du âgûylarına dahi bir hil'at lâzım olmağın anlara dahi bir beyaz sof münâsib görülüp hâk-i pây-i şerîfe arz olundu.

Mezbûra hil'at bir beyaz sof münâsib görülüp hâk-i pây-i şerîfe arz olundu. 


\section{Defterdar Efendi hazretleri arz eyledikleridir}

Kazıyye oldur ki hâs atlar Istabl-1 âmireye sığmayıp beş tavila at alır bir ahır dahi lâzımdır deyü mirâhurbaşı kulunuz arz eder, emr-i şerîf ne ise inâyet buyrula [altı bin akçaya arpa emini yapalım deyü cevâb vermeğin her kimesnenin ulûfesi başına birer yük otluk verilmek buyruldu, fî sâdis Receb sene 952. Meblağ-1 mezkûr mezbûra verilmek buyruldu, fì 6 Receb sene 952]

Kazıyye oldur ki ağa kullarınızın ve ba'zı kimesnelerin dahi her senede âdet-i otlukları olup hâliyâ divân-1 âlîde gelip taleb eyledikleri ecilden hâk-i pây-i sa âdet-bahşa arz olundu [her kimesneye otluk verilmek lâzım olanlara ulûfesinin bir akçe başına birer yük otluk verilmek buyruldu, fî 6 Receb sene 952]

Kazıyye oldur ki meş'alecilerden üç nefer kimesne çavuş olup meş'alelerin ve bârgirlerin vermezler bize in âm oldu derler emr-i şerîfiniz ne ise inâyet buyrula [bârgirleri ve meş'aleleri yerlerine gelen meş'alecilere verilmek buyruldu, fì 6 Receb sene 952]

Kazıyye oldur ki aşçlardan ve kapıcılardan çavuş olan ve bölüğe çıkanlar at ve bârgir ve yelek akçesin isterler, emr-i şerîfiniz ne ise inâyet buyrula [içeriden çıkan iç oğlanlarına verilip ma âdâ kimesneye verilmek câiz buyrulmadı, fî 6 Receb sene 952]

Kazıyye oldur ki iki akçe ulûfe ile helvacı şâgirdlerinden Mustafa altı akçe ulûfe ile ulûfeciler cemâ‘atine ilhâk olunup mezbûr bölüğü kabûl etmeyüp dört akçe ulûfe ile turşucu olmasın ricâ eder [dört akçe ulûfe ile helvacı ve turşucu olmak buyruldu, fî 6 minhu] ta'yîn

(s.40) Kazıyye oldur ki, sâbıka olan beş nefer en âmcılardan ziyâde altı nefer kimesne dahi fermân olunmuş emr-i şerîf mûcebince ta yîn olunan bunlardır ki zikrolunur, emr-i şerîfiniz ne ise inâyet buyrula [yevmî ikişer akçe ulûfe ile altı nefer kimesne enâmcı ta'yîn olunup ve imam hoca en'âm dưâsın okumak içün bir akçe terakki buyruldu, fî 13 Receb sene 952] ta'yîn

An-dânişmendân-1 Mevlânâ Hoca Efendi: Abdurrahman Halife; Sinan Halife; İshak Halife; Hüsam Halife

Kâtib Mehmed; Sinan Halife 
Ve bu cümleye bir duââ lâzım olup Mevlâna İmam Hoca sâir en âmcılardan bir akçe ziyâde ile du âcı olmasın ricâ eder Mevâcib-i cemâ‘at-i ehl-i hıref

An-cemâ‘at-i hayyâtîn tacyîn

Sinan ser-hayyâtîn, 10 [üç akçe ziyâde buyruldu, fî 13 Receb sene 952]

Hüseyin Macar, kethudâ-i hayyâtîn, 7 [iki akçe ziyâde buyruldu, fî târihin minhu]

Behram Çerkes ser-bölük-i hayyâtîn, 5 [bir akçe ziyâde buyruldu, fî târihin minhu]

Ali ütüger, 4 [bir akçe ziyâde buyruldu, fî sâlis-i Şaban sene 952]

An-cemâ'at-i sâire ta'yîn

Mustafa Kastamoni ser-zergerân, 7 [üç akçe ziyâde buyruldu, fî târihin minhu]

İbrahim ser-şimşirgerân, 7 [ziyâde buyruldu,fî târihin minhu, fî yevm 2]

Mustafa ser-mûzeduzân, 5 [ziyâde buyruldu,fî târihin minhu, fi yevm 2]

Mustafa ser-kazzâz, 6 [bir akçe ziyâde buyruldu, fî târihin minhu]

Ali kazganî, 5 [bir akçe ziyâde buyruldu, fî târihin minhu]

Ser-kemangerân, 3 [iki akça ziyade buyuruldu, fî târihin minhu]

Mevâcib-i mezkûrîn ta yîn

Mevâcib-i şehzâdegân neferen 3, fî 10, fî yevm 3. Ziyâde fermûde beher nefer fî 5: yekûn 15 [buyruldu, fî târihin minhu] Mevâcib-i vâlidegân-1 şehzâdegân, neferen 3, fî 8, fî yevm 24, ziyâde fermûde beher nefer fî 6: yekûn fî yevm 6 [buyruldu, fî târihin minhu]

Beş nefer arslancılar husûsunda emr-i şerîfiniz ne ise inâyet buyrula [küçük arslan alınmak buyruldu] 
(s.41) Mevâcib-i cemâ‘at-i tabbâhîn. ta'yîn

Fi'l-asl mevcûd neferen 31. Bu cümle vefâ eylemez bir şâgird dahi ricâ ederler

Mahmud Halife, 4. An-ebnâ-i sipahiyân şud. Becâyeş-i Mustafa an-şâgirdân-1 matbah, fî yevm 2 [buyruldu fì 13 Receb sene 952, fî yevm 4] naklubu

İbrahim Halife, 4. An-enderûn reft. Becâyeş-i İbrahim anşâgirdân-1 tabbâhîn, fî yevm 3 [ziyâde şud, fî yevm 1] nakluhu

Mustafa birâder-i Yahya, 2. Halife şud. Becâyeş-i Hüseyin birâder-i Mehmed Kul [buyruldu] [ba]ki

İbrahim b. Hüseyin, 3. Halife şud. Becâyeş-i Hasan b. Ahmed Bosna [buyruldu, fî yevm 5] [ba]ki

Mustafa b. Abdullah, 2. Kat' şud. Becâyeş-i Ali b. Hızır Arnavud [buyruldu fí yevm 2] [ba]ki

Mehmed b. Abdullah, 2. An-ulûfeciyân şud. Becâyeş-i Salih b. İbrahim [buyruldu, fî yevm 7] [ba]ki

Hüseyin birâder-i Süleyman, 2. Bevvâb şud. Becâyeş-i Mustafa b. Yusuf Arnavud [buyruldu, fi yevm 7] [ba]ki

Yusuf b. Abdullah, 2 bevvâb şud. Becâyeş-i Receb b. Hasan Kul [buyruldu fî yevm 2] [ba]ki

Bu sekiz nefer kimesnelere ziyâdeleri mukarrer olundu.

Cafer b. Abdullah, tâbi'-i ser- kilarî, ibtidâ (terkin, sahh)

Mevâcib-i habbâzîn

Fi'l-asl mevcûd neferen 14. On dört neferden ziyâde üç şâgird dahi ricâ ederler

Hızır b. Abdullah, 1,5. Müteveffâ şud. Becâyeş-i Mustafa b. Osman [buyruldu, fî yevm 2]

Malkoç b. Abdullah, 1,5. Girihte şud. Becâyeş-i İsa b. Yusuf [buyruldu fî yevm 2]

Yusuf b. Abdullah, 1,5. Girihte şud. Becâyeş-i Halil b. Behram [buyruldu, fi yevm 2] 
Ali b. Abdullah, 2. Halife şud. Becâyeş-i Budak b. İbrahim [buyruldu fî yevm 2]

Ahmed b. Abdullah, tâbi'-i ser-kilarî [bir buçuk akçe ile buyruldu] (sahh)

Mahmud b. Abdullah, tâbi'-i m. [kezâlik] (sahh)

Hamza b. Abdullah, tâbi'-i m [kezâlik] (sahh)

An-cemâ‘at-i şâgirdân-1 kiler

Mustafa-i Bosna, 2. Bevvâb şud. Becâyeş-i Veli b. Abdullah, fî yevm 2 [buyruldu, fî 13 Receb 952]

Kazıyye oldur ki rûznâmeci kulunuzun mahrûse-i Edirne'de sılası olup altı yılmış ki varmamış icâzet-i şerîfinizle gitmek murâd ederler, emr-i şerîf ne ise inâyet buyrula, gurre-i Ramazana dek gelmek üzere. Mezbûr rûznâmeci kulunuzun hızmetin görmeğe paşa hazretleri cânibinden rûznâme yazan Fazlullah bendenüze ve bu bendenüz cânibinden rûznâme yazan İsmail kulunuz ta'yîn olunmağiçün hâk-i pây-i sa âdet-bahşa arz olundu. Ve sipâhi oğlanları cemâ'atinden Emrullah bendeniz mezbûrun şâgirdi olup bile gitmeğin murâd eder [icâzet verildi, şâgirdiyle, fî 20 Receb sene 952]

Kazıyye oldur ki ağa kullarınızın âdet-i otlukları olup kirâsı husûsunda inâd ederler kadîmden kirâsını dahi avârızla buyurdurlarmış derler, amma verilürdü deyü ta'yîn eden kimesne yok, emr-i şerîf ne ise inâyet buyrula [kadimden alıgeldikleri eğer (?) ağayân ve sâir ehl-i divan otluğu buyurulup devesiyle taşınu gelmiş ise gerü âdet-i kadìm üzere otlukların taşıtasız deyü emr olundu, fî 20 Receb sene 952]

Kazzyye oldur ki vezzân kulunuzun mahrûse-i Konya'da sılası olup icâzet ricâ eder, emr-i şerîf ne ise inâyet oluna [icâzet verildi]

(s.42) Kazıyye oldur ki hâssa çadırlardan ikişer kapılı yirmi dörder hazîneli münakkaş iki adet divânhâne çadırı köhne olup amelden kalmışırı, emr-i şerîf ne ise inâyet buyrula [der-i devlete arz olunup taleb olunmak emr olundu, fi 27 Receb sene 952]

Ve otuzar hazînelü iki aded hazîne çadırları köhne olup amelden kalmıştır, emr-i şerîf ne ise inâyet buyrula [bunda işlemek buyruldu] 
Ve yirmi ikişer hazîneli iki aded kiler çadırları dahi köhne olup amelden kalmıştır emr-i şerîf ne ise inâyet buyrula [bunda işlemek buyruldu]

Kazıyye oldur ki sekbanlardan solak olup gaybet edip ve müteveffâ olanların yerlerine yazılacak bunlardır ki zikrolunur, emr-i şerîf ne ise inâyet buyrula [on altı nefer kimesnelere ikişer ulûfe buyruldu, fî 27 Receb sene 952] ta'yîn

Ahmed b. Abdullah Rodos. Tâbi'-i Haydar Ağa, becâyeş-i Ahmed ki gaybet- kerde; Yusuf b. Abdullah Arnavud. Tâbi'-i Haydar Ağa, becâyeş-i Muharrem ki gaybet-kerde; Mustafa b. Abdullah Avlonya, becâyeş-i Memi ki solak şud; Bostan b. Abdullah İstanbulî, becâyeş-i Hasan ki solak şud; Ali b. Abdullah Mora, becâyeş-i Mahmud ki solak şud; Yusuf b. Abdullah Vidin, becâyeş-i Mustafa ki müteveffâ şud; Mustafa b. Abdullah, becâyeş-i Derviş ki solak şud; Hamza veled-i Kul, becâyeş-i Memi-i Manastır ki gaybet-kerde; Yusuf b. Abdullah Mora, becâyeş-i Mehmed ki solak şud; Mustafa b. Şirmerd İstanbulî, tâbi'-i Cafer Ağa becâyeş-i Muharrem ki müteveffâ şud; Aydın b. Abdullah İstanbulî ki tâbi'-i Kâtib-i matbah, becâyeş-i Nasuh ki gaybet-kerde; Hızır b. Pir Ahmed İstanbulî, tâbi'-i Cafer Ağa, becâyeş-i Bali ki gaybetkerde; Memi veled-i Kul İstanbulî, tâbi'-i Hızır Ağa mirâhur-1 büzürg, becâyeş-i Husrev Çerkes ki müteveffâ şud

Emr olan elli kişiden üç nefer eksikdür ol üç neferün yerine zikrolanlar tezkire olundu: Hamza b. Abdullah Avlonya; Ramazan b. Abdullah Vidin; Hüseyin Bosna

An-cemâ'at-i gilmân-1 kiler ta'yîn

Hasan silahdar şud, fî yevm 2, becâyeş-i Ahmed bevvâb [bir akçe ulûfe buyruldu, fi 27 minhu]

Davud külhanân, teberdâr şud, fî yevm 1,5, becâyeş-i Yusuf Arnavud [bir buçuk akçe ulûfe buyruldu, fî 27 minhu]

An-cemâ'at-i teberdarân ta'yîn

Pervane, silahdar şud becâyeş-i Hasan teberdâr şud; Ali becâyeş-i Davud teberdâr şud [üç akçe ile buyruldu bu iki nefer] 
An-cemâ‘at-i ehl-i hiref

Mustafa Arnavud, ser-postindûz, fî yevm 6 [bir akçe terakki buyruldu, fî- sâlis-i Şaban sene 952]

Kazıyye oldur ki cemâ'at-i bevvâbînden Hacı Ahmed meş'aleî fevt olup elinde olan mîrî bârgiri hatunu içerüden çıkmış olmağın bârgir taleb olundukda in âm olundu deyü cevâb edüp vermezler, emr-i şerîf ne ise inâyet oluna [hatuna bârgir bahâsı nafaka buyruldu, fî târihin minhu]

Kazıyye oldur ki içerüden çıkan on üç nefer oğlanların on üç aded üsküfleri ki bin yüz beş miskal olup her miskali elli akçeden ellibeşbinikiyüzelli akçe eder hâliyâ taleb ederler, emr-i şerîf ne ise inâyet buyrula. Ve bundan gayri üçer yüz akçe dahi tirkeş bahâsı taleb ederler [ellişer akçe miskaline bahâları verilmek buyruldu, fî târihin minhu. Âdet-i kemân bahâsı üçer yüzden]

Kazıyye oldur ki Şair sipahi kulunuza on iki akçe ile müteferrikalık buyrulmuş, emr-i şerîf ne ise inâyet buyrula [yevmi on iki akçe ulûfe ile müteferrika cemâ'atine buyruldu, fi-sâlis-i minh]

Ve gûyende Baba Haydar Acem'e sekiz akçe buyrulmuş, emr-i şerîf ne ise inâyet buyrula [sâzende cemâ‘atine yevmî sekiz akçe ile buyruldu, fî-târih-i minh]

An-cemâ'at-i bevvâbîn

Hacı Ahmed meş'aleî, fî yevm 5, müteveffâ şud, becâyeş-i İskender bevvâb [buyruldu]. İskender bevvâb meş'alê̂, fî yevm 4, becâyeş-i Mezid, [hâliyâ hassa(?) timardan buyruldu]

Kazayye oldur ki Istabl-ı âmire kurbunda olan mescidde bundan akdem Mevlânâ Bali imâm olup hâliyâ gene iki akçe imâmet ricâ eder, emr-i şerîf ne ise inâyet buyrula [yevmî iki akçe ulûfe ile imâm olmak buyruldu, fi-sâlis-i minh] ta yîn

Mirâhur-1 küçek yoldaşlarıyla varıp hâssa develere otluk yükledip bârgirlere verilmek buyruldu, fi târihin minhu]

Kazıyye oldur ki içerüden çıkan oğlanlar bârgir taleb ederler emr-i şerîf ne ise inâyet buyrula [küçük mirâhurdan her bir bârgiri getürmek buyruldu, fî Şaban sene 952] 
Kazıyye oldur ki Marmara kazâsına tâbi‘ Alayundlu nâm karye kurbunda Saruhanoğulları'ndan Abdurrahman'ın definesi vardır deyü Selime nâm hatun i'lâm eder. İş bu mezkûre Selime mezkûr Abdurrahman'ın kızıdır [Ramazan Kethudâ'ya varup görülmek buyruldu, fî Şaban sene 952]

Dârüssa âde kethudâsının kışlağı bin akçe ziyâde buyrulmuş, emr-i şerîf ne ise inâyet buyrula [buyruldu, yazlık dahi bin ola] 2500; k. 1500, baki 1000

Kazıyye oldur ki Mısır'a gönderilen Seydi Gazi bendeleri Mısır'dan bu cânibe avdet etdükde beş cenâh şahin ve zağanosa istihdâm içün bir doğancı koşulup ve mahrûse-i Antalya'ya geldikde dört nefer hisâr erleri koşulup bu cânibe getürdüler, hâliyâ mezkûrlar icâzet taleb ederler, emr-i şerîf ne ise inâyet buyrula [Doğancıya bin akçe ve hisar erlerine altıyüz akçe verilmek buyruldu, fî 10 minhu] ta' $y \hat{n} n$

Mehmed, bâzdâr an-Misır âmed

An-cemâ'at-i mustahfizân-1 kal'a-i Antalya

Hacı İlyas, Ali, Lutfi, Ahmed

(s.44) İn âm-1 hazret-i pâdişâh-1 âlem-penâh -hullide mülkuhu-

Gılmân neferen 4

Haydar Çerkes, fî yevm 3, oda-i küçek nihâde; Cafer Çerkes, fî yevm 3, teberdâr; Süleyman Çerkes, fî yevm 2, an-cemâ'at-i tabbâhîn; Nasuh Çerkes, mu'allim-i esbân-1 hâssa dâde, fî yevm 2 [buyruldu, fi 17 Şaban sene 952]

Nakkaş Ferruh, an-ebna-i sipahiyân-1 dergâh-1 âlî; gulam 1 nefer [buyruldu, fi 17 minhu]

Yusuf bin Hasan, fi yevm 3, yerine nihade

Mezbûrların ulûfeleri husûsunda emr-i şerîf ne ise inâyet buyrula

Kazıyye oldur ki bundan akdem sa âdet ile İzmir câniblerine şikâra çıkıldıkda Samed Baba Tekkesi'ne mescid binâ olunmak içün iki bin akçe in âm olunup mezkûr ikibinün bin akçesi mescid binâsına konulup binin dahi murâbahaya verilüp vezâyifine verilmek buyrulup hâliyâ kadıdan arz getürüp yalnız binâsına ikibin sekizyüz 
akçe harç olunmuş [beşyüz akçe zâ[vi]yedâra verilmek buyruldu, fî 17 minhu]

Kazzyye oldur ki dârüssa âde kethudâsına beş akçe terakki buyrulmuş emr-i şerîf ne ise inâyet buyrula, fî yevm 25, k. 20,5 [Buyruldu, fî 10 minhu]

Kazıyye oldur ki çadır mehterleri başısı Hamza bendenüzün on dört akçe ulûfesi olup bundan akdem iki akçe terakki buyrulmuşdu, kethudâsının dahi sekiz akçe ulûfesi olup ol dahi terakki ricâ eder, emr-i şerîf ne ise inâyet buyrula [mehterler kethudâsına yevmî iki akçe terakki buyruldu, fî $2 \mathrm{~N}$ sene minhu] ta yîn

Kazıyye oldur ki hâssa atlardan altı re’s yedek atların sıkarlat çukadan olan çulları köhne oldu deyü mirâhur bendeleri yenicek olmak murâd edinirler emr-i şerîf ne ise inâyet buyrula [evvel bahârda hâzır ola deyü emr olundu, fî 2 N sene 952]

Çultar 6, beher çultar fî 6 zirâ', 36 zirâ‘, beher zirâ‘ fî 150: 5400 . Seksen çulu kırmızı sof isterler

Çultar 6, fî 6 zirâ‘dan 36 zirâ‘ beher zirâ‘ fî 150: 3780. Kırmızı samırset çukası isterler

Mezkûr çultarlara bıtâne olmak içün yetmiş iki zirâ‘ çuka-i gazzâziye isterler: 2000

Kazzyye oldur ki Mirâhurbaşı Hüseyin Ağa kulunuz âdet-i otluk ricâ eder, emr-i şerîf ne ise inâyet buyrula [üç bin akçe buyruldu, fî 2 minhu]

Kazıyye oldur ki mahrûse-i Manisa'da Mehmed b. Abdülkerim duâgûyunuz ehl-i ilm vâiz hayr duâasın alacak kimesne olup el-ân câmi'-i şerîfde nasihat eder, bin akçe sadaka olunmak içün emr-i şerîf ne ise inâyet buyrula [bin akçe sadaka buyruldu, fî 9 N sene 952] ta'yîn

Kazyyye oldur ki Kırovası'nda Sarı Işık demekle ma'rûf azı̂z dahi hayr du'âsın alacak azîzdir bin akçe sadaka olunmak içün emr-i şerîf ne ise inâyet buyrula [bin akçe sadaka buyruldu, fî $9 \mathrm{~N}$ sene 952] ta yîn

Kazzyye oldur ki müfti efendi du'âgûyunuza ve hatîbe îd-i mübârekde birer sof kaftan verilmek âdetdir emr-i şerîf ne ise inâyet buyrula [birer sof kaftan verilmek buyruldu] 
(s. 45) Kazıyye oldur ki Mısır'dan gelen kapı oğlanlarına dörder akçe ulûfe buyrulmuş emr-i şerîf ne ise inâyet buyrula [dörder akça ulûfe buyruldu, fî $9 \mathrm{~N}$ sene 952] ta'yîn

Kazıyye oldur ki geçen yıl at yarakçısına dört yüz akçelik bir benek kaftan ve oğlanların yüzer akçelik ve üzerlerine duran bölükbaşısına üçer yüz akçe verilip bu yıl dahi ricâ ederler, emr-i şerîf ne ise inâyet buyrula [Şahkulu'na dörtyüz akçe bölükbaşısına ikiyüz akçe iki oğlana yüzer akçe inâyet buyruldu, fî $9 \mathrm{~N}$ sene 952] ta'yîn

Kazıyye oldur ki bundan akdem ahrete intikal eden Ridvan Ağa bendelerinin Hürmüz nâm hızmetkârına bir saraclık düşdükde tevcîh olunmak buyruldu, hâliyâ bir deveci gedüğü düşüp deveci ulûfesinden mezkûr Hürmüz bendeleri sarac olmak ricâ eder emr-i şerîf ne ise inâyet buyrula [yevmî üç akçe ulûfe ile sarac buyruldu, fî $10 \mathrm{~N}$ sene 952] táyin

Kazıyye oldur ki dış kapı oğlanlarına âdet-i kadîme üzere birer hil'at verilüp dârüssaâdede olan beş nefer kapı oğlanlarına dahi yedişer yüz akçe hil'at bahâ buyrulmuş emr-i şerîf ne ise inâyet buyrula [beş nefere $\mathbf{7 0 0}$ akçeden üç bin beş yüz akçe verilmek buyruldu, fî 12 minhu] ta' $y \hat{i n}$

Kazıyye oldur ki içerüden çıkan ağalara üçer bin akçe ester bahâ verilmek âdet olup hâliyâ çaşnigirbaşı olan Ali Ağa bendeleri dahi inâyet umar, emr-i şerîf ne ise inâyet buyrula

Kazıyye oldur ki bundan akdem içerden ağalığa çıkan Rıdvan Ağa bendelerine üçbin akçe ester bahâ verilip hâliyâ çaşnigirbaşı olan Ali Ağa bendeleri dahi inâyet umar emr-i şerîf ne ise inâyet buyrula [üç bin akçe ester bahâ buyruldu, fî 16 minhu] táyîn

Kazıyye oldur ki hâliyâ iki akçe mevâcib ile olan kimesne esbâb kalaylandıkda mu'âvenet içün ırgad tutulurdu, Cafer b. Ahmed nâm şâgirdime bir akçe ulûfe olursa cümle hızmeti edâ edeyin deyü cevâb eder, emr-i şerîf ne ise inâyet buyrula [bir akçe ulûfe ile şâgird buyruldu, fî $23 \mathrm{~N}$ sene 952] ta'yîn

An-cemâ‘at-i şâgirdân-1 tabbâhîn

Kasım b. Hayreddin, 2. Müteveffâ şud, becâyeş-i Memi b. Abdullah; Hüseyin b. Abdullah, 2, girihte şud becâyeş-i Veli 
b. Abdullah [ikişer akçe ulûfe ile iki nefer şâgird buyruldu, fî 23 minhu] ta'yîn

Kazıyye oldur ki mirâhur bendeleri bir yem ricâ eder, emr-i şerîf ne ise inâyet buyrula [bir at yemi buyruldu, fî târihin minhu]

Kazzyye oldur ki, hassa altun eyerlerden biri bozulup tekrar işlenme*

Kazıyye oldur ki beş yüz altmış dirhem hâssa altın eyerlerden biri bozulup tekrar işlenmekçün mahrûse-i İstanbul'a göndericek lâzım geldi, ne tavır üzre buyurulur ise inâyet oluna [arabî işlenmek buyruldu, fî-sâbi'-i Şevvâl sene 952]

An-şâgirdân-1 habbâzîn

Ali b. Abdullah, 1,5.girihte şud, becâyeş-i Mehmed birâder-i Sinan [buyruldu fî 7 minhu] ta'yîn

An-cemâ'at-i çakırcıyân

Hasan b. Yahya, 3 müteveffâ şud becâyeş-i Cafer anatmacacıyân; Cafer an-atmacacıyân, 2 an-çakırcıyân becâyeş-i Eymir [buyruldu, fî-sâbi'-i minh] ta yîn

An-cemâ‘at-i şâgirdân-1 sarrâcîn-i bârgirân

Derviş b. Murad, 1. Gaybet-kerde, becâyeş-i Abdi b. Abdullah; Veli b. Abdullah, 1. Gaybet-kerde, becâyeş-i Mehmed b. Abdullah; Ahmed birâder-i Kul, 1. Gaybet-kerde, becâyeş-i Mehmed b. Hüseyin [buyuruldu, fî-sabi-i minh, 1 akça ile] tayin

Kazıyye oldur ki Rüstem Paşa Hazretleri'nden atlar getüren ademlerin beyân eder, mezbûrlara emr-i şerîfiniz ne ise inâyet buyrula

Davud, mezbûrlara re'is konulmuştur [mezkûra bir seraser kaftan ve dörtbin akçe harçlık buyruldu, fî 14 Şevvâl sene 952]

İki nefer sarac, fî 300, 600 akçe in âm. Bir nefer seyis, yüz akçe

Mevâcib-i başıllk an-cemâât-i küştîrân, fî yevm 4. Mezbûr pehlivan başlık saâdetlü sultanım hazretlerinin huzûr-1 şerîflerinde Pehlivan Ahmed ile güreşip Pehlivan Ahmed'e terakki in âm

* Gerisi eksik bırakılmış aşağıda devam edilmiş. 
buyrulup mezbûr başılık dahi uhdelerine terakki olunmasın ricâ eder [bir akçe ziyâde buyruldu, fî 14 minhu] ta'yîn

Tafsîl oldur ki pâdişâh hazretlerinden ulûfesi olup bu cânibe gelen saracları beyân eder [on iki nefer saraca birer akçe terakki buyruldu, fî 14 Şevvâl sene 952] ta'yîn

Ramazan b. Hudaverdi, 7,5; Nazar ser-bölük, 6,5; Memi-i mataracı, 7; Ferhad Sığla, 5,5; Ferhad Dündar, 6,5; Mustafa-i İskenderiye, 5; İlyas b. Musa, 5,5; Musa b. Kul, 5,5; Hasan Trabzonî, 5,5; Sadi b. Süleyman, 5; Mahmud b. Ahmed, 6; Hızır b. Kethudâ, 4

Kazıyye oldur ki mahrûse-i Konya'da sultânü’l-ârifîn şeyhü'lmüdekkıkîn Mevlânâ Celâleddin-i Rumî Hazretleri'nin türbe-i şerîflerinde sa âdetlü sultanım hazretleri cânibinden yevmî iki akçe vazîfe ile cüz' tilâvet eden Mevlânâ Şücâ du'âgûyunuza bir in âm sadaka buyrulmuş ki mezbûr türbede tilâvet kıla emr-i şerîfiniz ne ise inâyet buyrula [mezâr-1 şerîf üzerinde cüz' okunduktan sonra izdiyâd olmak içün bir inầm olmak içün hızâne-i âmireden Mevlânâ Şüca'a yevmî iki akçe cihet buyruldu, fî 21 Şevvâl sene 952] ta yîn

Kazıyye oldur ki mahrûse-i Konya'da Şeyh Kadı b. İzzeddin Câmi' i evkafı yerinde mîrî cânibinden bir ekmekçi fırını ve bir tavukhâne binâ olunmuştur [mezkûr tavukhâne ve firın tevâbi iyle câmi'-i mezbûre hademesiyle vakf olmak buyruldu, ki her cum'a gecesi hayr dua edeler]

(s.47) Mevâcib-i Yusufb. Abdullah şâgird-i mâstgirân, girihteşud becâyeş-i Hüseyin b. Abdullah, şâgird-i mâstgirân, fî yevm 1,5 (terkin) an-cemâ'at-i şâgirdân-1 mâstgir

Yusuf b. Abdullah, girihte şud, becâyeş-i Hüseyin b. Abdullah, 1,5 [buyruldu, fí 6 Za sene 952] naklubu

Kazıyye oldur ki Hasan nâm kimesne pehlivan nefirzen olup Âsitâne-i sa âdet-bahşdan dirlik olmasın ricâ eder [yevmî yedi akçe ulûfe ile boruzen olmak buyruldu, fî 6 minhu] nakluhu

Mevâcib-i cemẩat-i nefirzenân fî 6 ve 8

Kazıyye oldur ki Sefer b. Ahmed nâm kimesne yevmî üç akçe ulûfe ile gûyende olsun deyü fermân olunmuş, emr-i şerîfiniz ne ise inâyet buyrula [üç akçe ulûfe buyruldu, fî 13 Za sene 952] nakluhu 
Kazıyye oldur ki Miskalî Hüsam ve kemânkeş bendelerinüzün âdet-i aşları olup ricâ ederler, emr-i şerîf ne ise inâyet buyrula [ikisine birer aş buyruldu, fî târihin minhu]

Mevâcib-i Ahmed b. Pir, şâgird-i postindûz, fî yevm 1. Mezbûr ulûfesine buçuk terakki olmasın ricâ eder [buçuk ziyâde buyruldu, fî târihin minhu]

An-şâgirdân-1 tabbâhîn

Mustafa b. Yusuf Arnavud, 2. Girihte şud, becâyeş-i Mehmed b. Abdi birâder-i Devlethan bevvâb [buyruldu, fî târihin minhu] ta'yîn

Kazzyye oldur ki hızâne-i âmire ve divân-1 âlî kâtiblerinin âdet-i îdiyeleri olup kadîmden verili gelmiş imiş hâliyâ bunlar dahi ricâ ederler, emr-i şerîf ne ise inâyet buyrula [buyruldu, fî târihin minhu]

Mehmed Bey, tevki î: 1000; Mehmed Bey, kethudâ-i bevvâb: 500; Mahmud Çelebi, kâtib-i divân: 500; Mehmed Çelebi, kâtib-i divân: 500; Hüsrev Bey divitdar ve kâtib-i hükkâm: 500; Nesimi Bey, kâtib-i divân: 500; İbrahim Çelebi rûznâmeî: 500; Kurd Çelebi mukataâî: 500; Süleyman Çelebi tezkireî: 500; Hüseyin Çelebi, muhasebeî: 500; Fazlullah. Kâtib-i hazret-i Paşa: 500; İsmail Bey, kâtib-i defterdar efendi: 500; Ali şâgird-i mukata'â̂, 200; Musluhiddin vezzân: 400; Hamza-i Niğde, ser-mehterân-1 hayme: 200. Yekûn: 7300

Kazayye oldur ki kâtib-i kütüb Muhyiddin du'âcınız bir aş ricâ ederler, emr-i şerîf ne ise inâyet buyrula [bir aş verilmek buyruldu, fî $\mathbf{4}$ Zilhicce sene 952] ta'yin

Cemâ‘at-i sekbanân Yusuf b. Abdullah, Arnavud.

Mezkûr gaybet edüp yerine Hüsrev Çerkes sekban olmak ricâ eder, emr-i şerîf ne ise inâyet buyrula [buyruldu, fî $\mathbf{4}$ minhu], fî $5 \mathrm{Z}$ sene 952, kayd şud ta'yîn

(s.48) Kazayye oldur ki sârbân Nasuh'un oğlu İvaz beş akçe ulûfe ile deveci iken yine kendü ulûfesiyle sarac olmasın ricâ eyler ve mezkûrun elinde olan katara mezbûr sarbân Nasuh ulûfesiz kendü hızmetin eylemeği uhdesine almışdır [sarac bölüğüne ulûfesiyle buyruldu ve 
devesin dahi babası hımet ettirmek buyruldu fî 4 Zilhicce sene 952] ta'yîn

Kazıyye oldur ki emr-i şerîf ile müceddeden binâ olunan kasr-1 humâyûna hizmet edüp inâyet ricâ eden bendeleridir ki zikrolunur. ta'yîn

Mehmed b. Piri, sipahioğlanı emin-i binâ fî yevm 8 [bir akçe ziyâde buyruldu, fî $4 \mathrm{Z}$ Sene 952]

Yusuf b. Velid kâtib-i harc-1 hâssa ve kâtib-i binâ-yı mezbûr, fî yevm 7 [bir akçe ziyâde buyruldu]

Behram b. Musa Çavuş, fî yevm 3 [bir akçe ziyâde buyruldu, fî târihin minhu]

Hacı Mustafa b. Mehmed saraydâr, fî yevm 3 [bir akçe ziyâde buyruldu, fî̀ târihin minhu]

Kazzyye oldur ki sâbıka olan şehzâdeler hocasına îdiye bir hil'at verilirmiş emr-i şerîfiniz ne ise inâyet buyrula [bir sof kaftan verilmek buyruldu, fî 18 minhu] ta'yîn

Kazzyye oldur ki sultan hazretleri -dâmet ismetuhâ- devlet ü saâdetle bu cânibe müteveccih olduklarında saâdetle istikbâle buyurmağa ba'zı matbah tầifesinden ve mehterden ba'zı şâgirdlere bârgir vefâ etmeyüp semerlü kirâ davarına binmek lâzım gelür, binmeğe ta'allül ederler, emr-i şerîf ne ise inâyet buyrula

İnâm-1 hazret-i pâdişâh-1 âlem-penâh -hullide hilâfetuhu- anyed-i Seydi Çavuş an-merdümân-1 hazret-i Rüstem Paşa -dâmet meâlihu-. Gılmân-1 acemiyân neferen 12. ta'yîn

Minhâ: be-tabbâhîn dâde, neferen 5, [birer buçuk akçe ulûfe buyruldu, fî 18 minhu]; be-habbâzîn dâde, neferen 3 [birer buçuk akçe ulûfe buyruldu, fî 18 minhu]; be-1stabl dâde, neferen 4, be-seyisan-1 esbân-1 hâssa dâde. Şâgirdân-1 kadîm fî 1, şâgirdân-1 kadîm an-habbâzîn fî 2 ve 1,5. An-tabbâhîn fî 2 ve 1,5

Mezbûrlara mevâcib emr-i şerîfinizle ne ta'yîn olunur inâyet buyrula 
Kazıyye oldur ki kazzâz başı bendelerinden bir buçuk akçe ulûfe ile Hüseyin nâm bir oğlan şâgirdi olup sanấatini tekmîl edüp bir ibrişim oyan başlığı işleyüp içerüye vermiş bu husûsda emr-i şerîfiniz ne ise inâyet buyrula [ulûfesi üzre buçuk ziyâde buyruldu, fî 18 minhu] tajîn

Kazıyye oldur ki hâliyâ edviye alınan Davit'e (?) emr-i şerîfiniz ne ise inâyet buyrula [yevmî iki akçe ulûfe buyruldu, fî 18 minhu] ta'yîn

Kazıyye oldur ki Âsitâne-i sa âdetten oğlanlar getüren Seydi Bey’e iki bin akçe ile bir döşeme çatma hil'at verilmek münâsib gibi emr-i şerîfiniz ne ise inâyet buyrula [buyruldu, fì 18 minhu] ta'yîn

(s.49) Kazıyye oldur ki Yahudi Abraham tabîbe bir yem ihsân olunmuş emr-i şerîfiniz ne ise inâyet buyrula [buyruldu, fi-gurre-i Muharrem sene 953]

Kazıyye oldur ki sefer-i humâyûn vâki' oldukda bir sancak başı dahi lâzımdır deyü alaybeyi ve miralem bendenüz arz ederler [işlenmek buyruldu, fî $12 \mathrm{M}$ ]

Câmi'-i Hatuniye hatîbi arz oluna [bir sof kaftan verilmek buyruldu]

Kazıyye oldur ki Âsitâne-i sa âdetten inâm olup gelen cebehâne-i âmireye hızmet etmek içün lâzım olan bunlardır ki zikrolunur

İbrahim ser-şimşirger, fî yevm 9; Yusuf meşáleî, tâbi'-i Haydar Ağa ser-bevvâbîn, fî yevm 5; Yusuf b. topçu Süleyman, mehter-i sâbık-1 merhûm Sultan Mehmed -tâbe serâhu- der-cebehâne-i İstanbul bude, 4. Hâliyâ iki akçe ile kabûl eder; Abdi 
Osmanl Taşrasında Saray Bürokrasisi: Şehzade Selim’in Kazayâ Defteri

Abstract — Osmanlı klasik çağında XVI. yüzyıl sonlarına kadar hanedana mensup şehzadelerin, tecrübe kazanmak üzere gönderildikleri sancaklardaki idari uygulamaları konusunda ciddi bir kaynak eksikliği söz konusudur. Bununla beraber tarafımdan Başbakanlık Osmanlı Arşivi'nde şehzade divanında tutulan bazı defterler ilk defa teşhis edilmiş ve bunların hem şekil hem de mahiyetleri üzerine bazı değerlendirmeler yapılmıştır. Burada yayımlanan defter de şehzade divanına ait olup daha çok tayin, terfi ve mali konuları ihtiva eden küçük tezkirelerden ve üzerinde yer alan kararlardan oluşmaktadır. Kanuni'nin oğlu Şehzade Selim’in (II.) Manisa'daki idareciliğinin ilk yıllarını (1544-1546) içine alan ve onun görüşüne sunulan tezkireleri ihtiva eden bu kayıtlar "kazıyye" şeklinde sunulduğu için "kazayâ defteri” adıyla tarafımdan tanımlanmıştır. Defterdeki konular Osmanlı taşrasında hanedan mensubu bir idarecinin karşı karşıya kaldığı meseleler ve ilgilendiği hususları anlamak bakımından önemli olduğu kadar, bürokratik olarak taşradaki şehzade divanının işleyişi hakkında da fikir vermektedir.

Anahtar kelimeler: Kazayâ defteri, Şehzade Selim, Şehzade divanı, Taşra bürokrasisi, Manisa Saray 1 


\section{Bibliyografya}

\section{Arşiv Belgeleri}

Başbakanlık Osmanlı Arşivi (BA), D.BŞM, nr. 23

İstanbul Bab Mahkemesi Sicilleri, nr. 3

Topkapı Sarayı Müzesi Arşivi (TSMA), nr. D. 34, D. 9873; E. 6058/1.

\section{Yayınlanmış Eserler}

Arıkan, Zeki (nşr.): "Manisa’nın 1 Numaralı Şer'iyye Sicilindeki Osmanlı Tarihi”, Osmanl Araşttrmaları, X (1990), s. 99-136.

Bayerle, Gustav (ed.): The Hungarian Letters of Ali Pasha of Buda 1604-1616, Budapest: 1991.

Beldiceanu Steinherr, Irène - Ganchou, Thierry: "Tarhaniyat/Menemen, de Byzance a l'Empire otoman”, Turcica, 38 (2006), s. 47-122.

Bilgin, İlhami: "Manisa Sarayı", 9. Milletlerarası Türk Sanatları Kongresi, Bildiriler, Ankara 1983, s. 41-54.

Emecen, Feridun M.: XVI. Asırda Manisa Kazası, Ankara: Türk Tarih Kurumu Yayınları, 2013.

Emecen, Feridun M.: "Osmanlı Divanının Ana Defter Serileri: Ahkâm-1 Mîrî, Ahkâm-1 Kuyûd-1 Mühimme ve Ahkâm-1 Şikâyet”, Türkiye Araşttrmalar Literatür Dergisi, III/5 (İstanbul 2005), s. 107-139.

Emecen, Feridun M.: Osmanl Klasik Çağında Hanedan Devlet ve Toplum, İstanbul: Timaş Yayınları 2011.

Emecen, Feridun M.: "Şehzadenin Mutfağı: III. Mehmed'in Şehzadelik Döneminde Manisa Sarayına Ait Bir Mutfak Masraf Defteri”, Taribin İcinde Manisa, Manisa: Manisa Belediyesi Kültür Yayınları, 2007, s. 73-114.

Emecen, Feridun M.: "Taşra Bürokrasisinin Kaynakları: Şehzâde Divan Defterleri”, Tarih Boyunca Türk Tarihinin Kaynaklarn Semineri: Bildiriler (İstanbul 1997), s. 91-100.

Emecen, Feridun M. - Bostan, İdris: “Dubrovnik Arşivi’ndeki Osmanlı Belgeleri ile İlgili Rapor”, Belleten, LXII/235 (Ankara: 1999), s. 917-920. 
Emecen, Feridun M. - Şahin, İlhan: "Osmanlı Taşra Teşkilatının Kaynaklarından 957-958 (1550-1551) Tarihli Sancak Tevcih Defteri”, Belgeler, XIX/23 (Ankara 1998), s. 53-121.

İpşirli, Mehmet: "Beylerbeyi”, TDV İslâm Ansiklopedisi, VI (Ankara 1992), s. 73.

Mete, Zekai: "Osmanlı Taşrasında Bürokratik Muamelat: Sancakbeyi Belge ve Defterleri”, Osmanlı Araştırmaları, XIX (1999), s. 181-221.

Öztürk, Necdet (Nşr.): “Kazasker Vusûlî Mehmed Çelebi ve Selim-nâme’si”, Türk Dünyası Araştırmaları, 50 (İstanbul 1987), s. 9-108.

Sándor, Takáts - Ferencz, Eckhart - Gyula, Szekfü (Ed.): A Budai Basák Magyar Nyelvü Levelezése 1553-1589, Budapest: 1915.

Sevin, Necla A.: "Bozdağ ve Gölcük'teki Yok Olan Osmanlı Yayla Sarayları", Küçükmenderes Harman, I/5 (Ödemiş: Mayıs 2012), s. 14-15.

Tok, Emine: Manisa Yakınlarında Bir Ortaçă̆ Kalesi: Yoğurtçu Kale, Manisa: Manisa Belediyesi Kültür Yayını 2012.

Uluçay, Çağatay: "Kanuni Sultan Süleyman ve Ailesi ile İlgili Bazı Notlar ve Vesikalar", Kanuni Armağanı, Ankara: Türk Tarih Kurumu Yayınları, 1970, s. 237-241.

Uzunçarşılı, İsmail Hakkı: "Sancağa Çıkarılan Osmanlı Şehzadeleri”, Belleten, XXXIX/156 (Ankara 1975), s. 659-696.

Üçbaylar, Enis: "Saray-1 Âmire (Manisa Sarayı), Manisa, I (1982), s. 39-46. 
ŞEHZADE SELİM'İN KAZAYÂ DEFTERİ

3

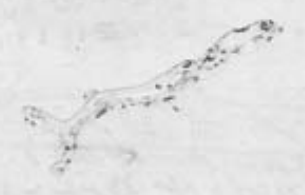

\section{2}
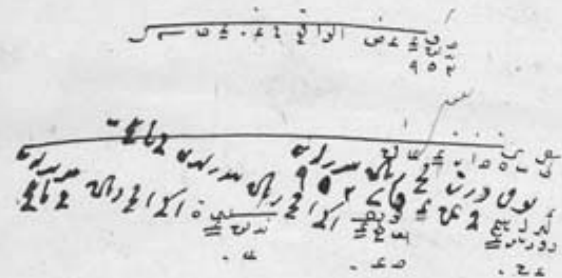

in

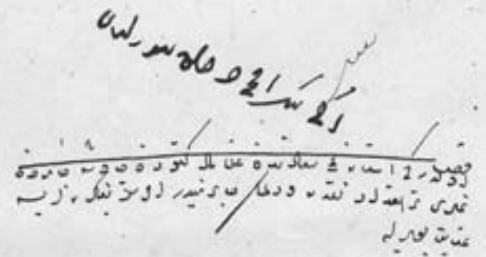

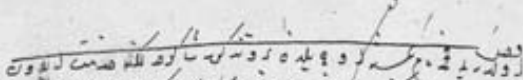

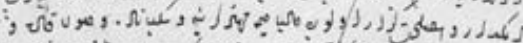

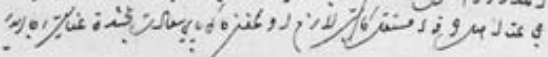

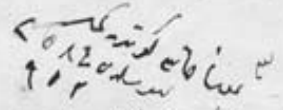
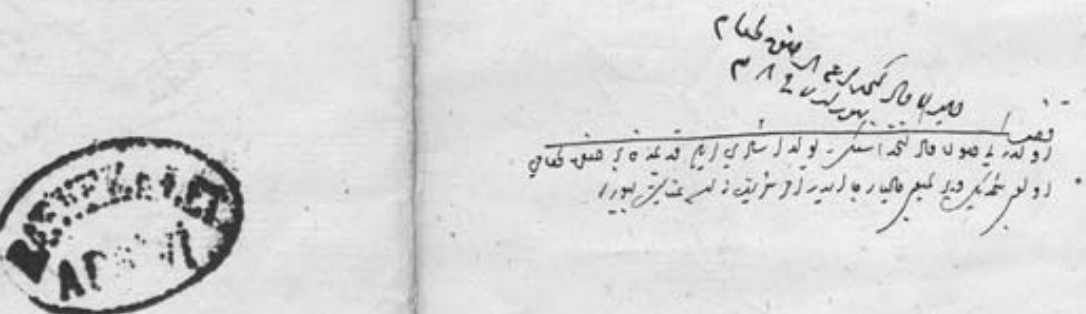
FERİDUN M. EMECEN
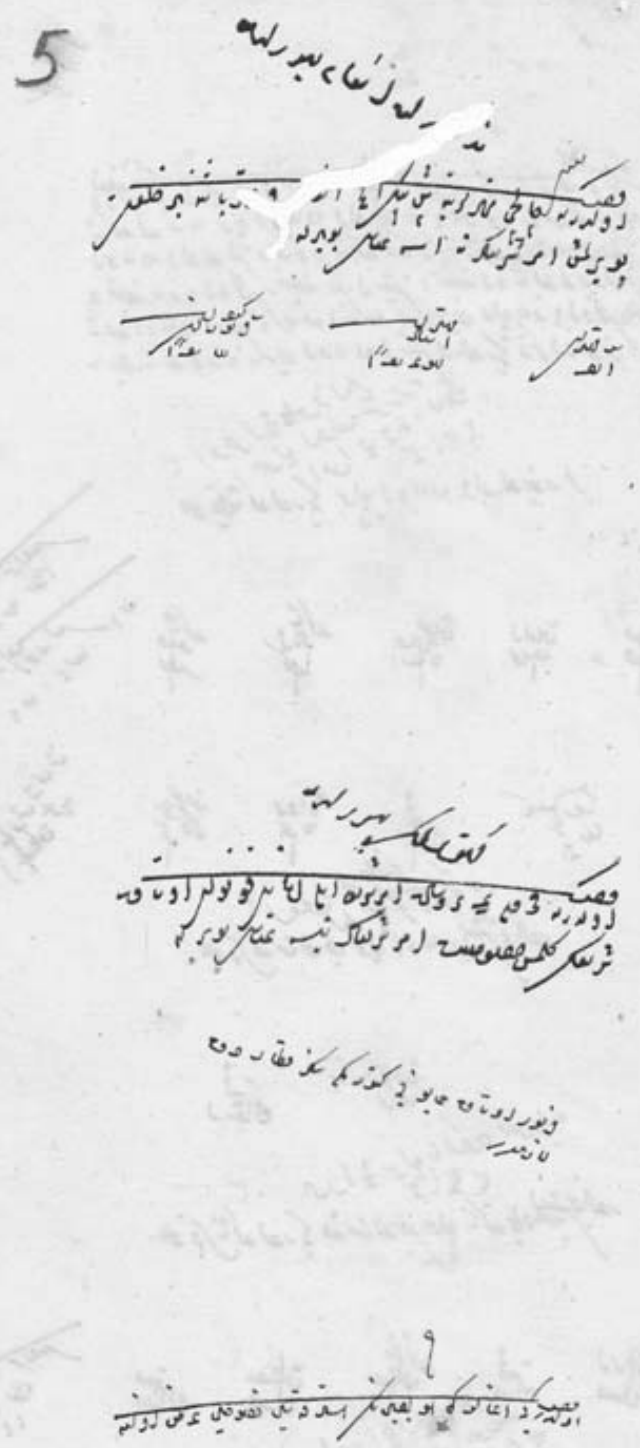

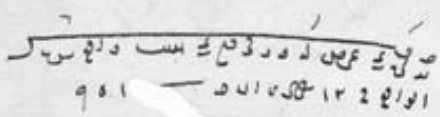

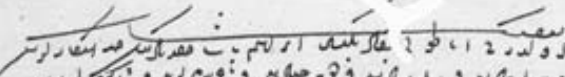

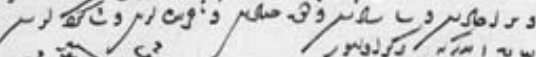
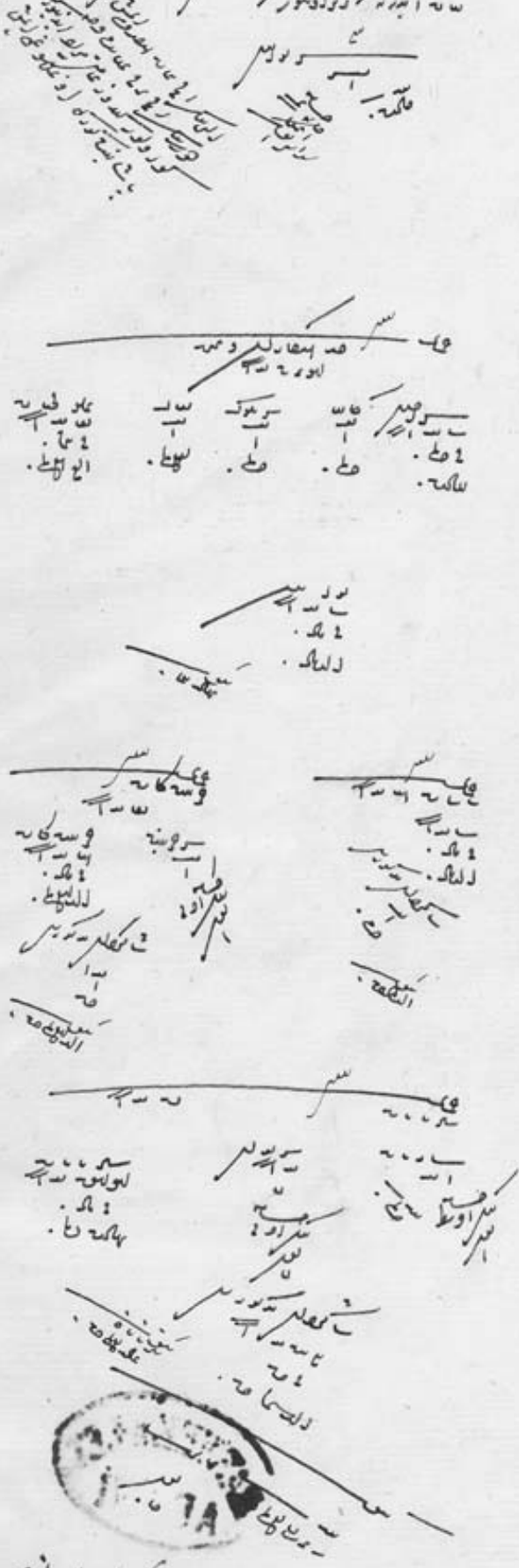

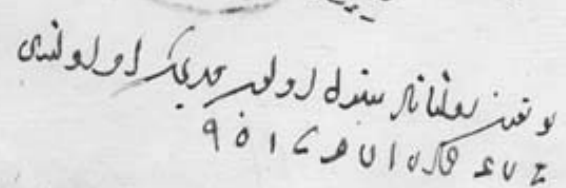




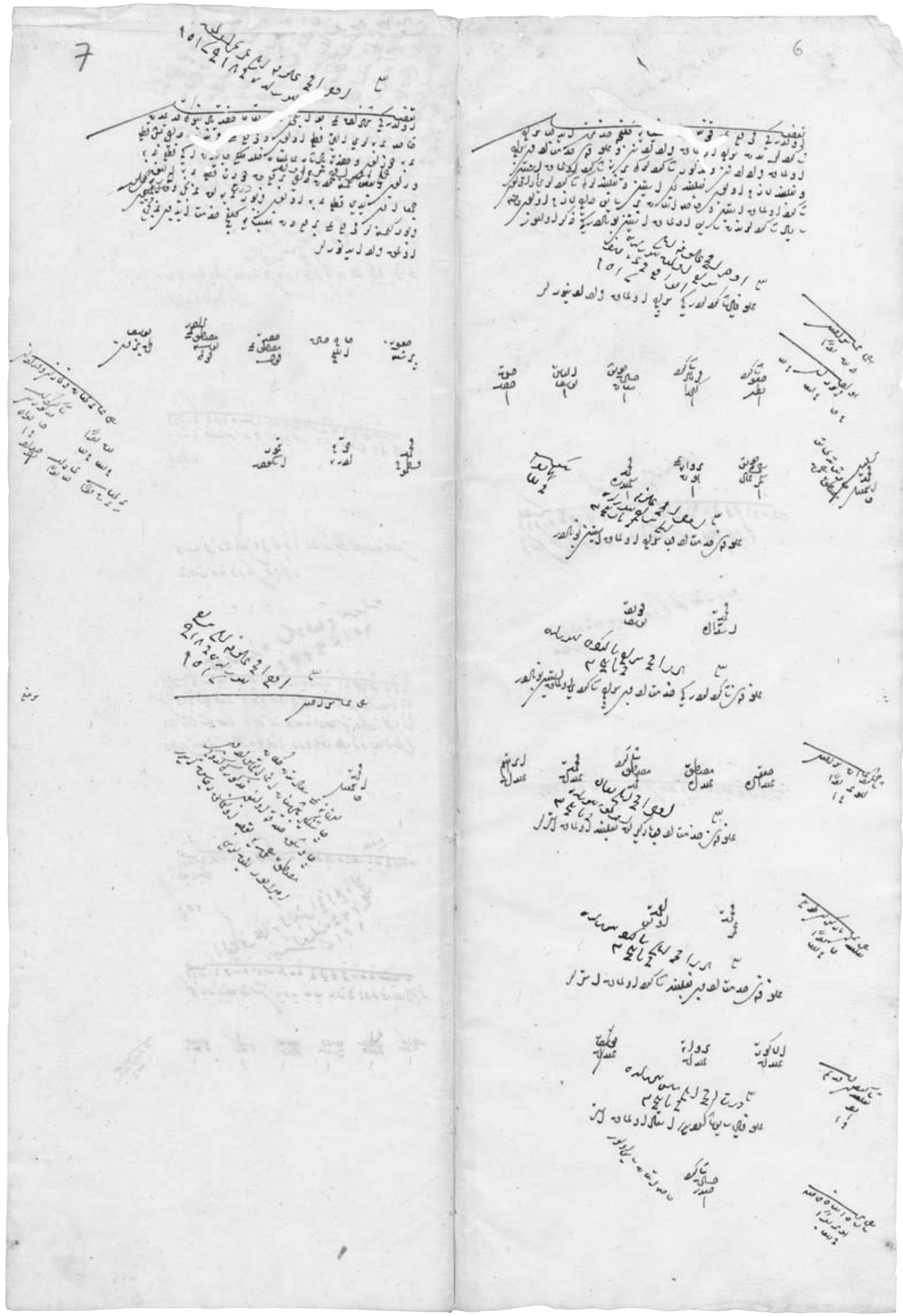




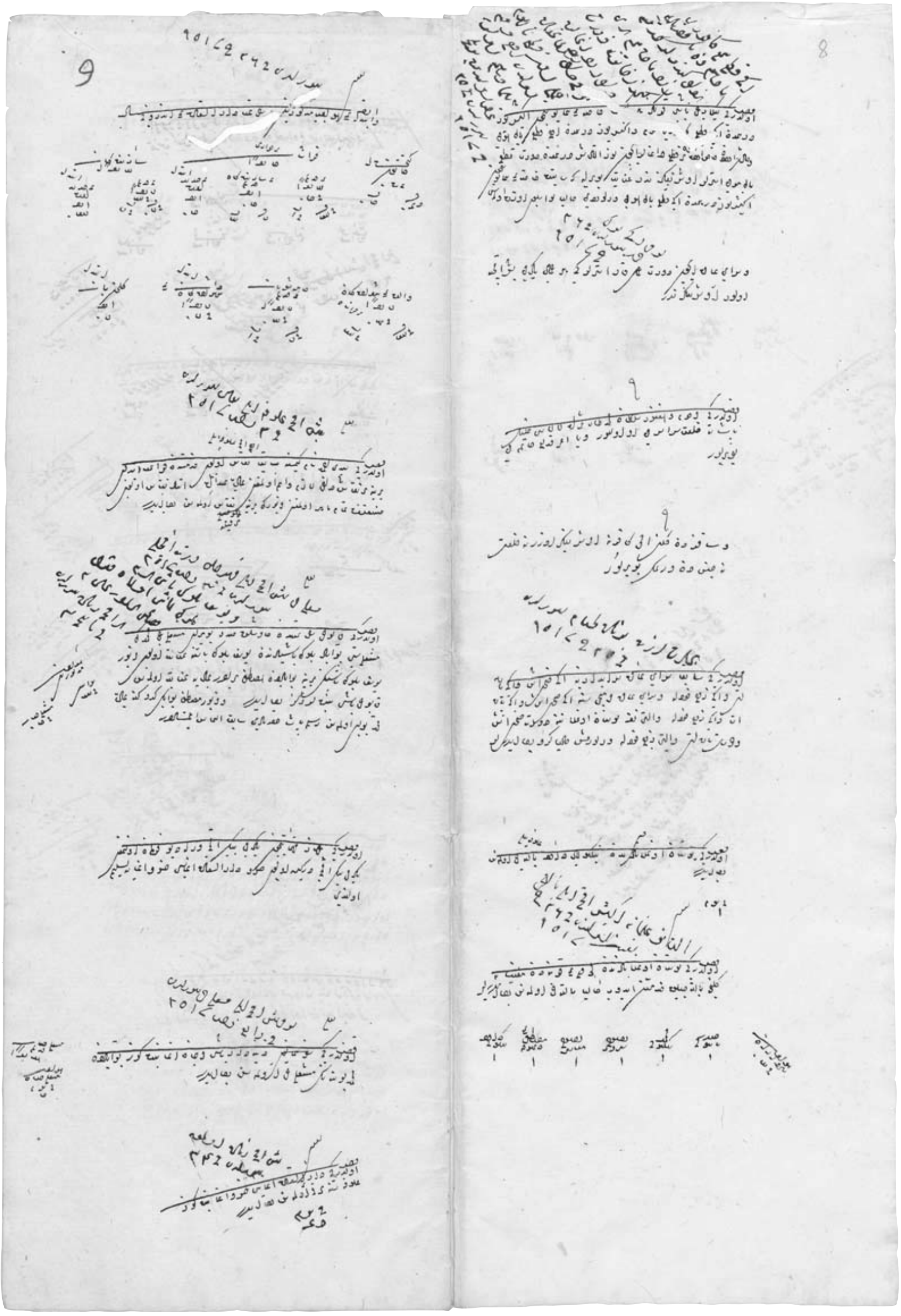




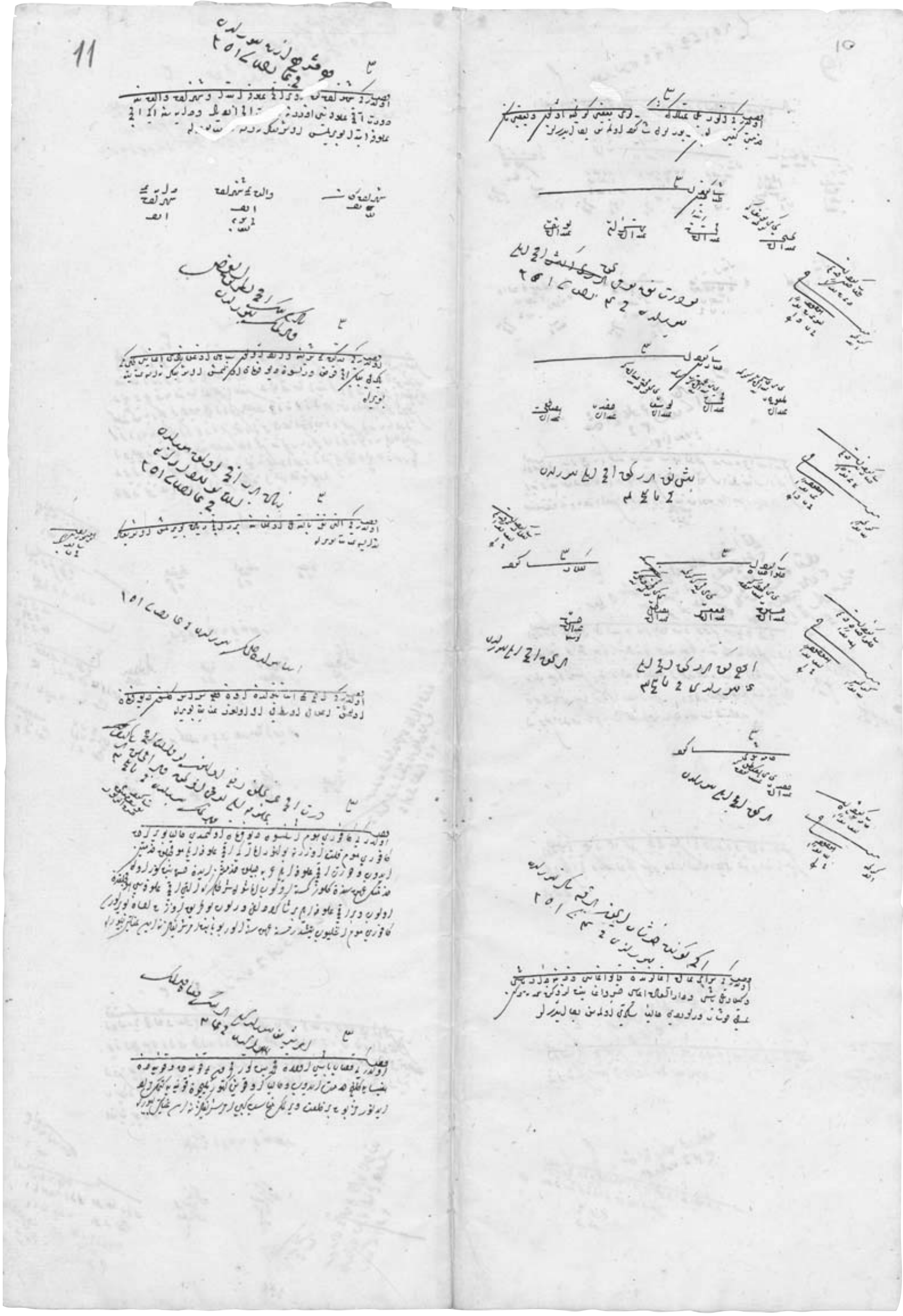




\section{3}

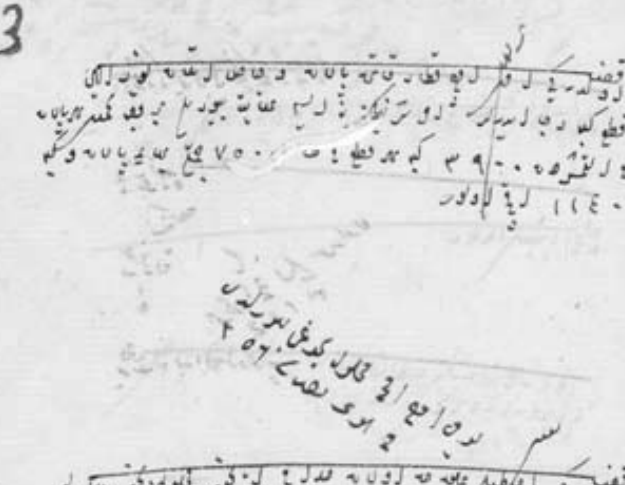

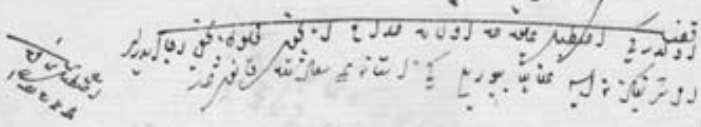

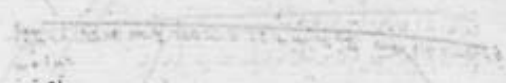

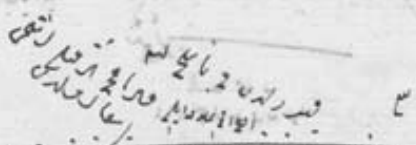

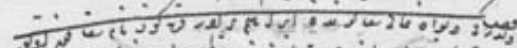

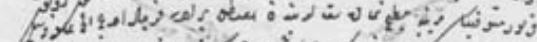
20.

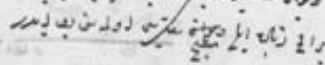
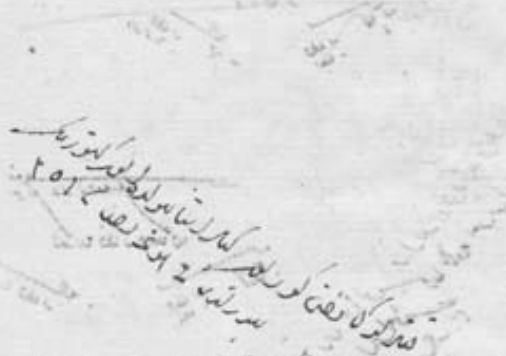

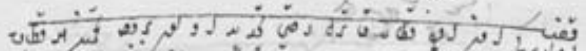

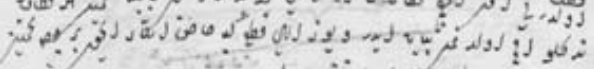

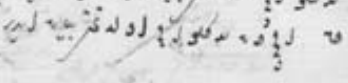
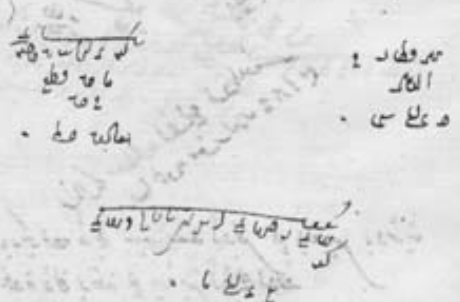

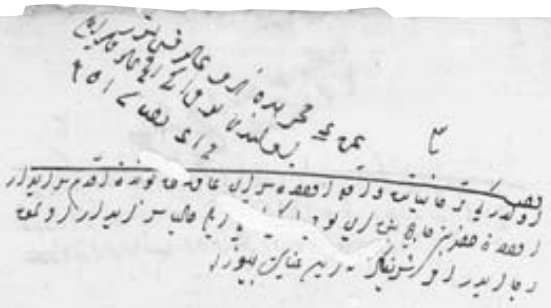

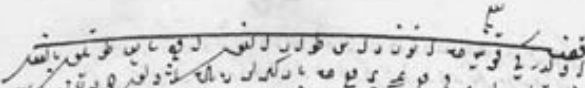
هذ:

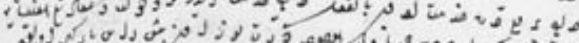
每 Mivo

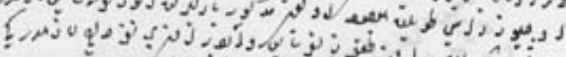

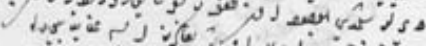

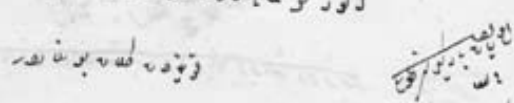

然

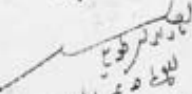

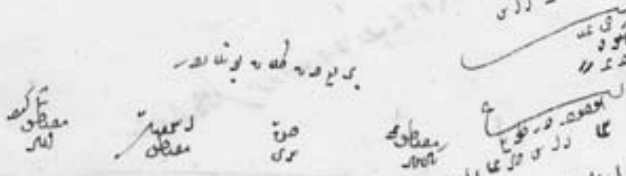

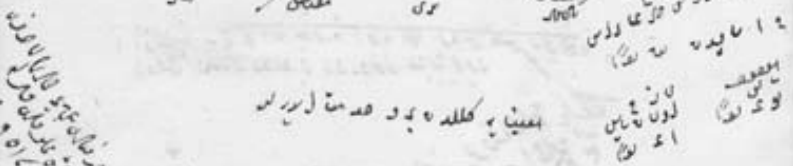

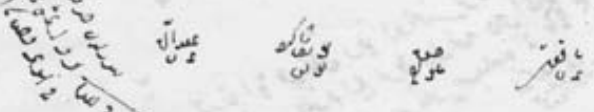

तो

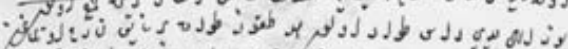

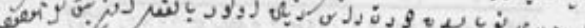

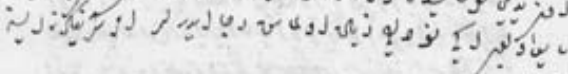

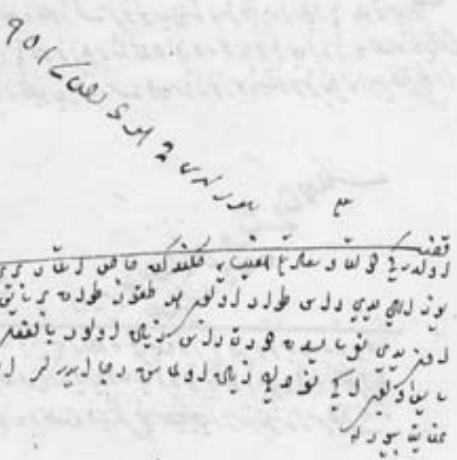

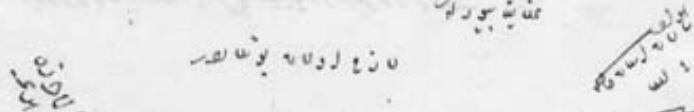

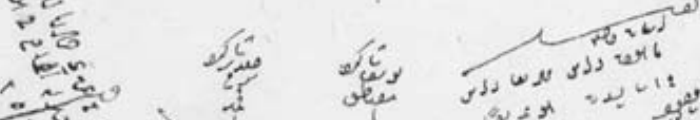

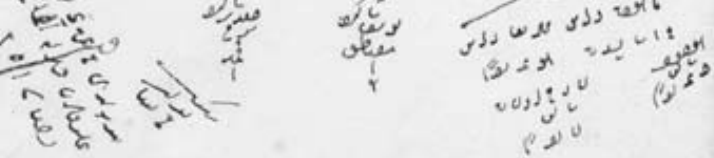
(C) 
ŞEHZADE SELİM'İN KAZAYÂ DEFTERİ

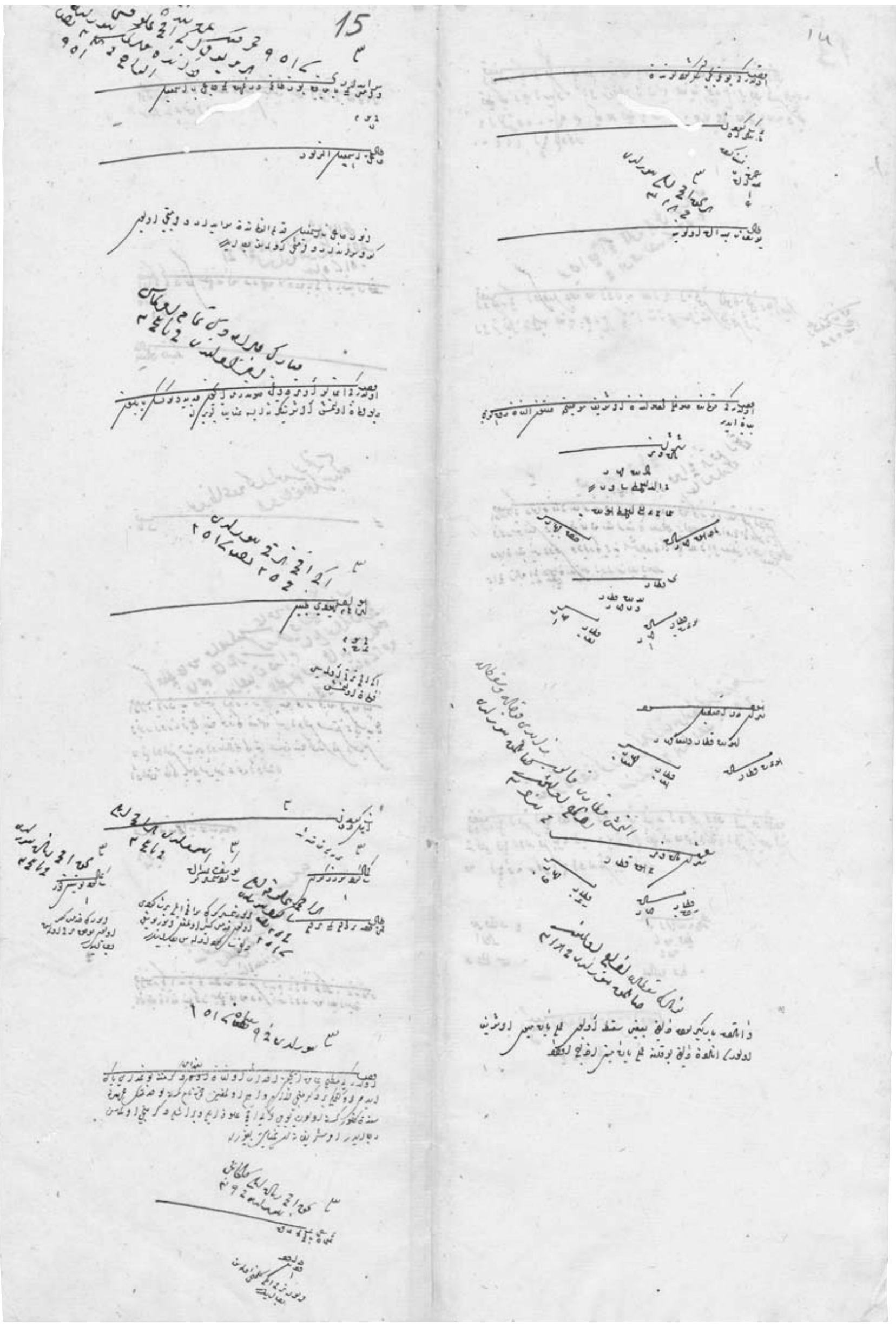


FERİDUN M. EMECEN
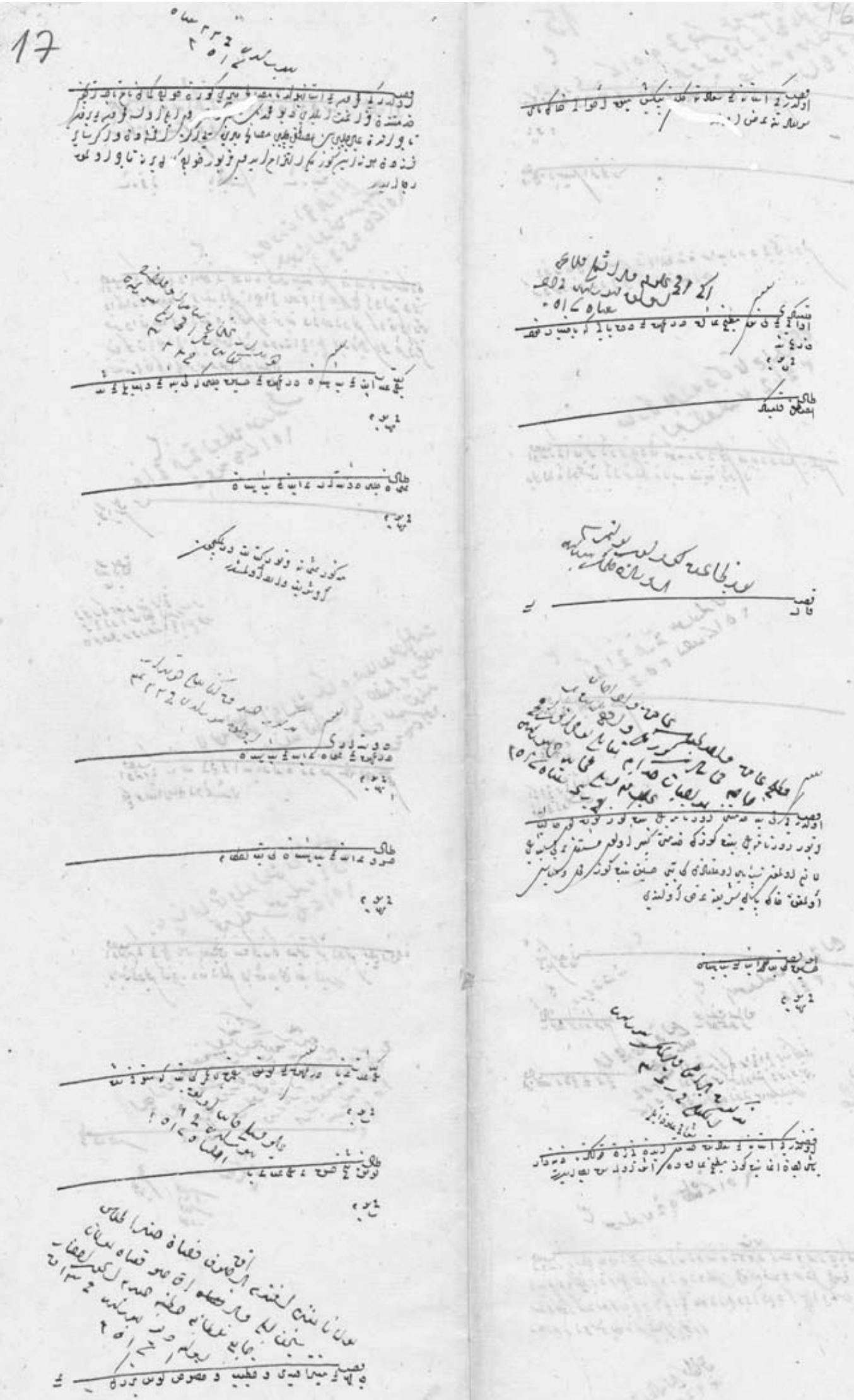
19
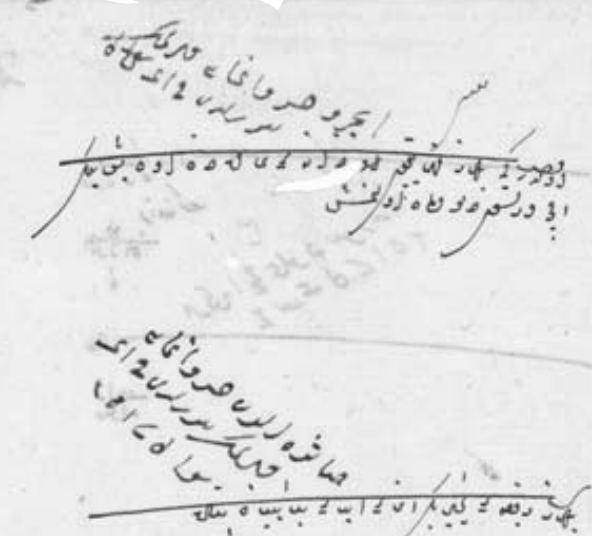

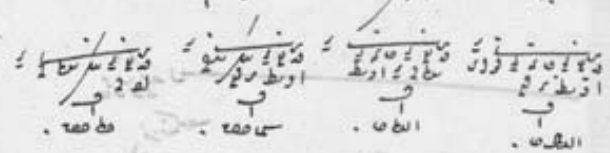

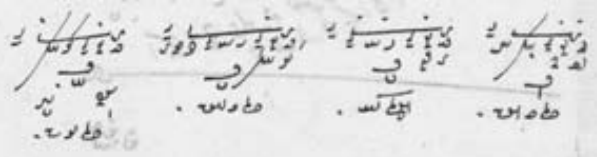

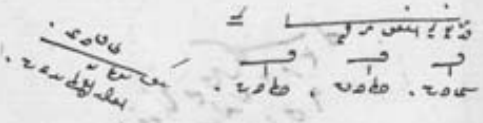

2

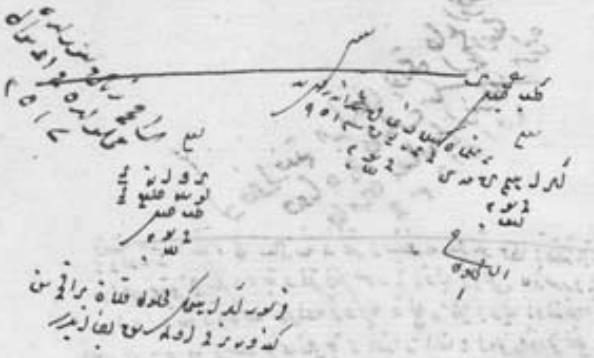

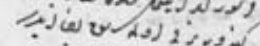
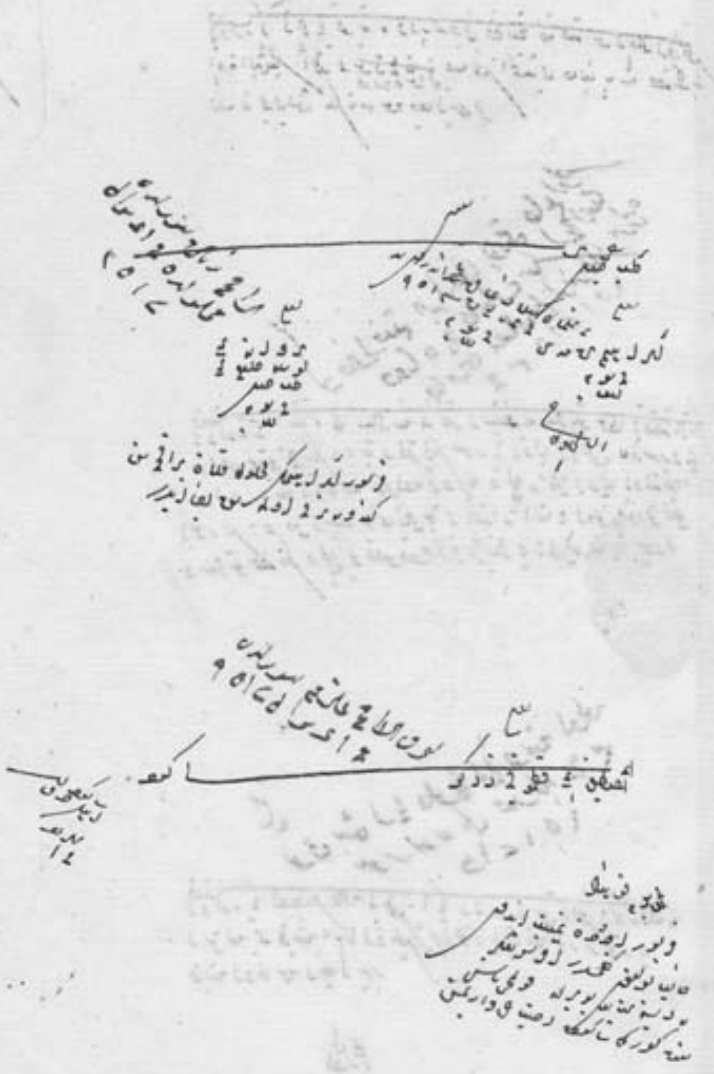

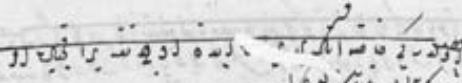

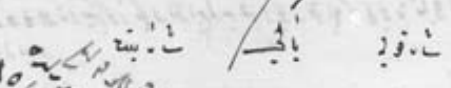

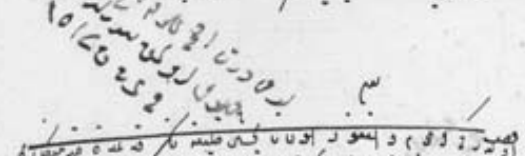

का فرو

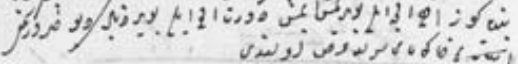
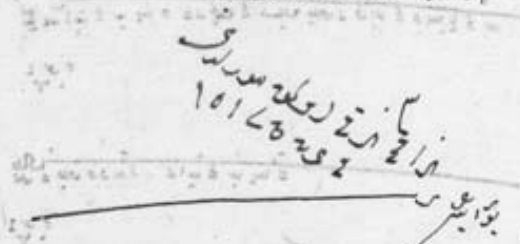

ب.

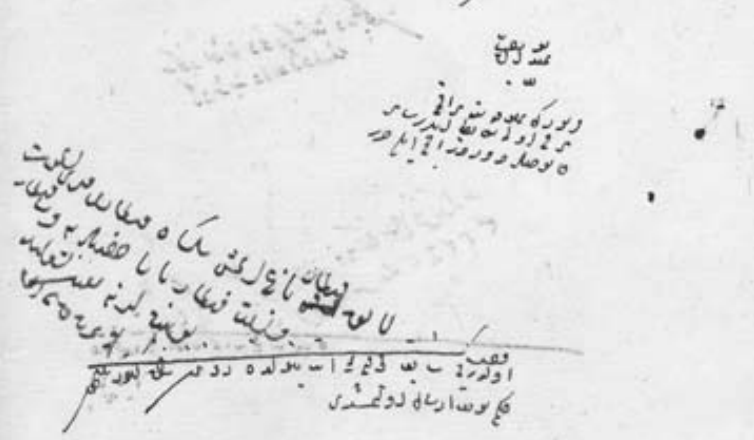

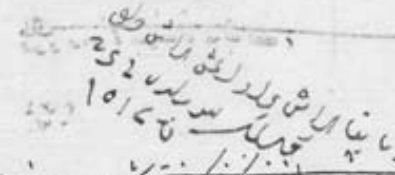

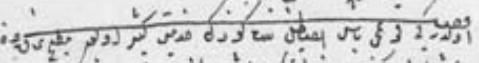
2.

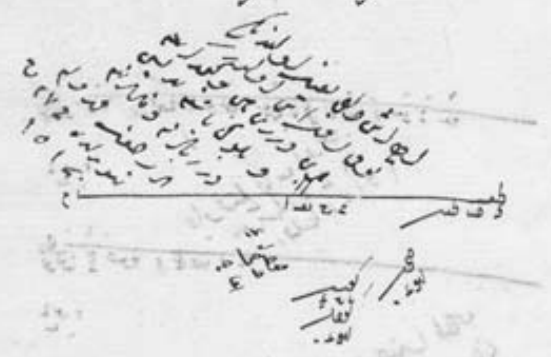


FERİDUN M. EMECEN

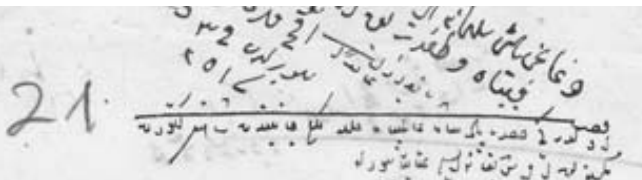

$$
\begin{aligned}
& \text { 13: } \\
& \text { … }
\end{aligned}
$$

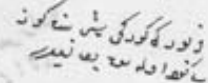

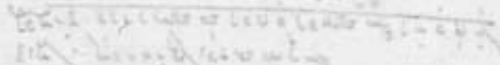

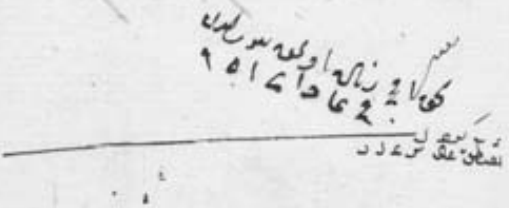

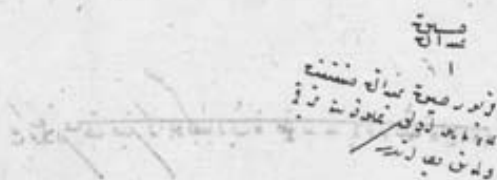

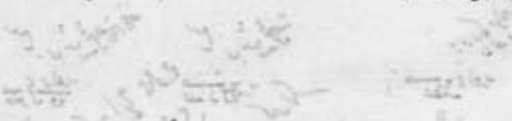

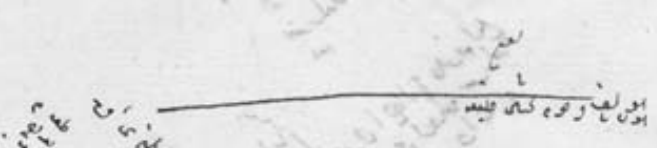

हis

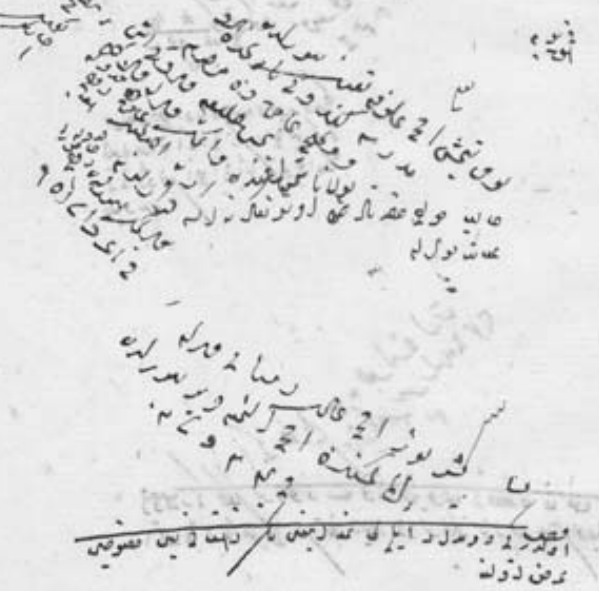

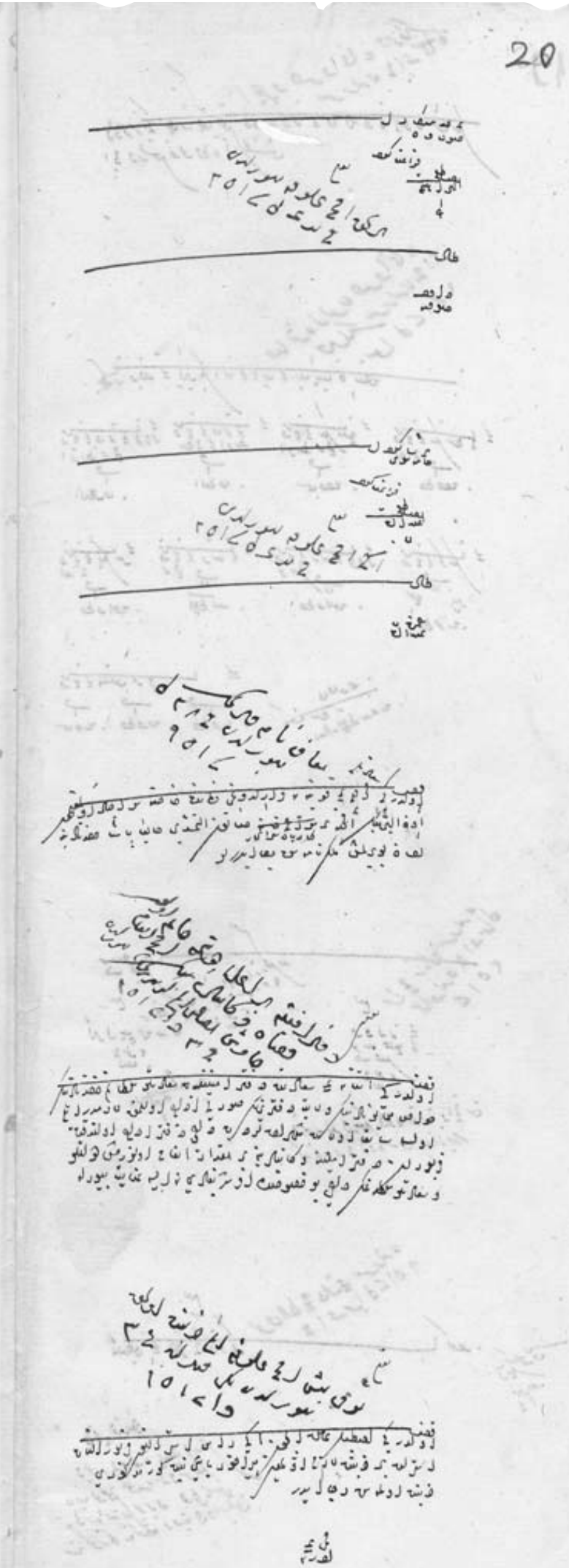


ŞEHZADE SELİM'İN KAZAYÂ DEFTERİ

23
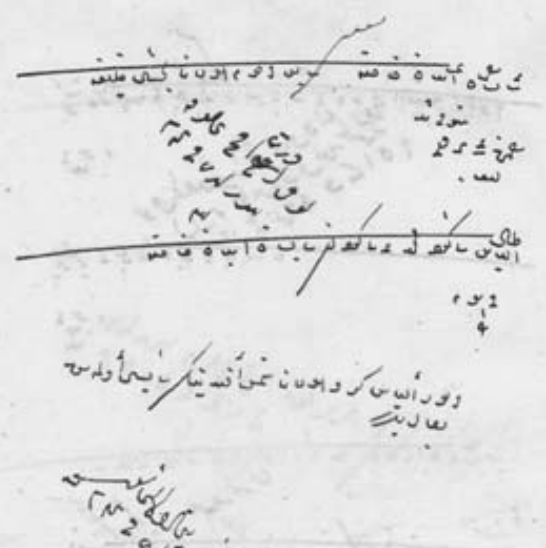

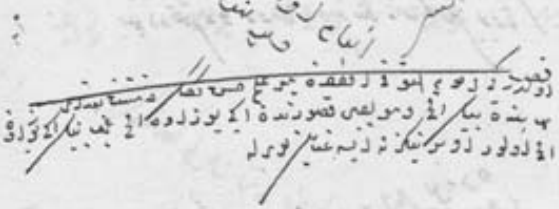
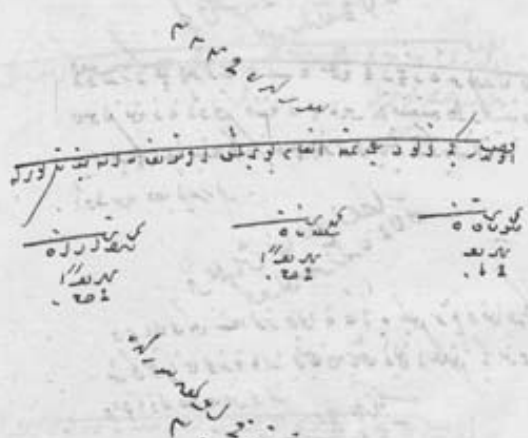

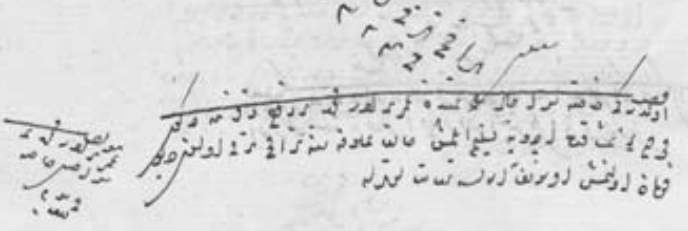

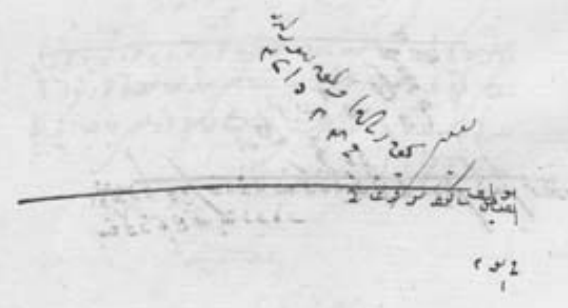

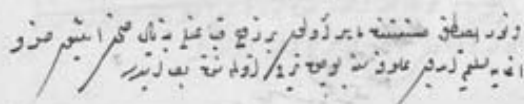
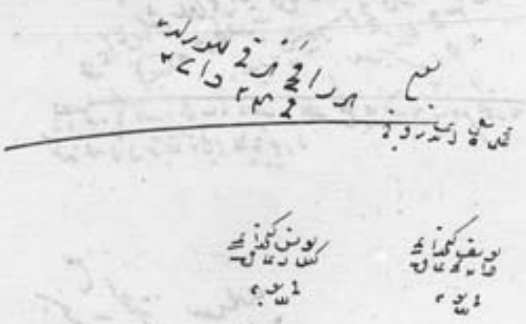

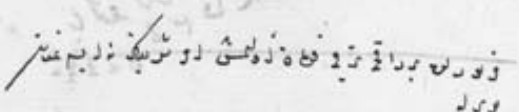

$$
\text { I.S. }
$$

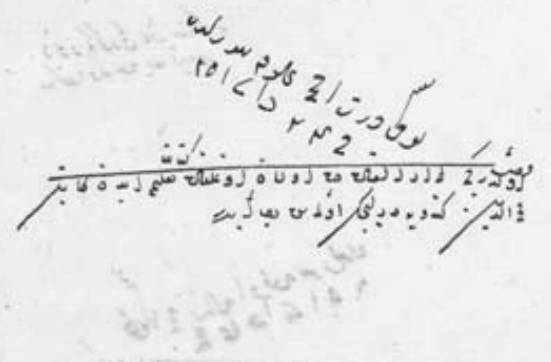

itis

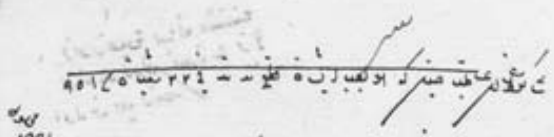

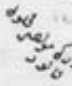

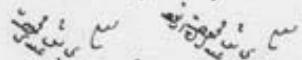

बint

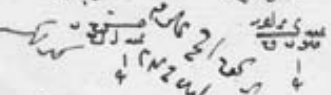

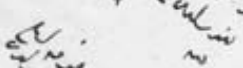

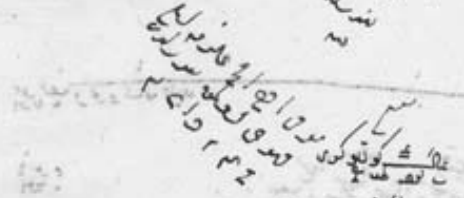

it:?

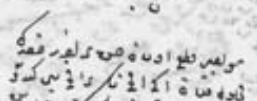

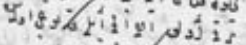

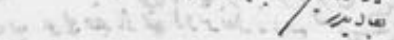

2021.6

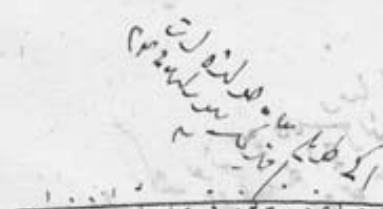

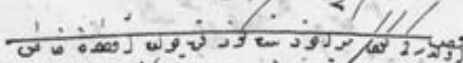

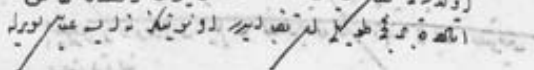


FERİDUN M. EMECEN

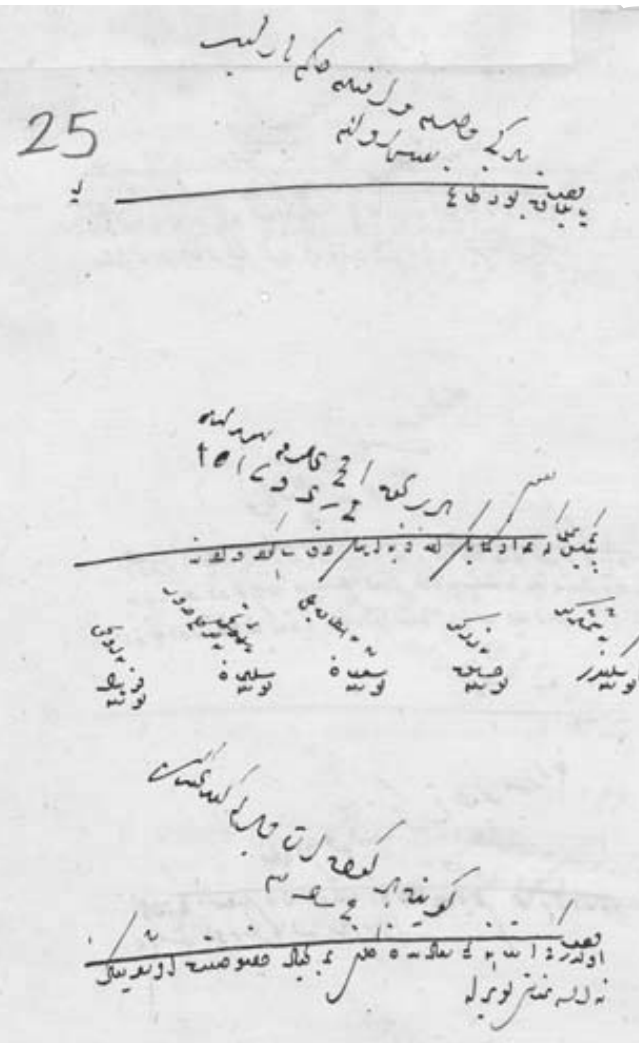

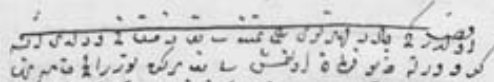
2. का لvن

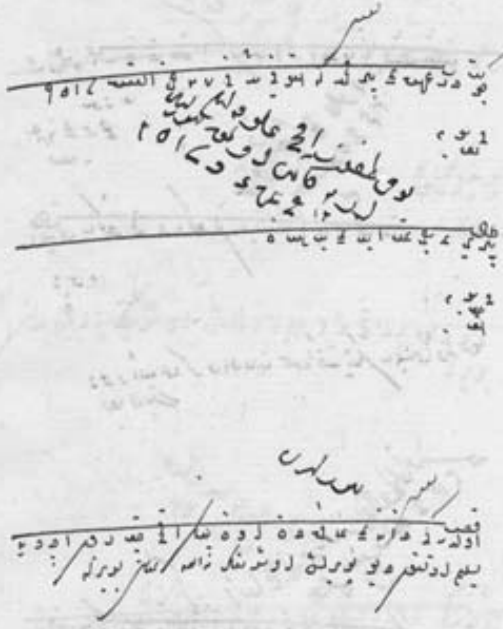
S. 0.

sos

$10,4)^{2}$ ?

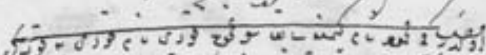

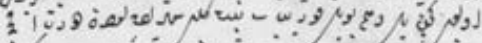

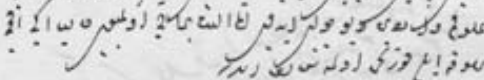

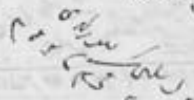

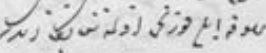

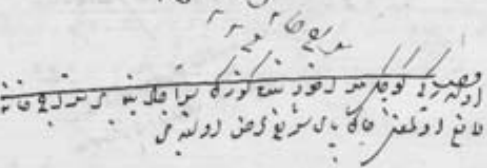

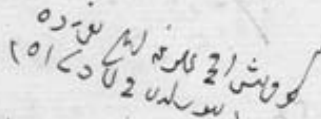

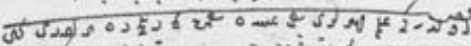

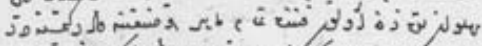

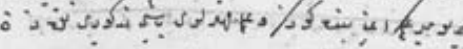

$$
\text { íli }
$$

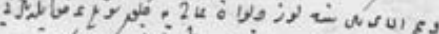

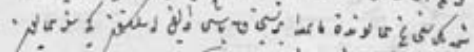

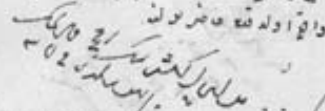

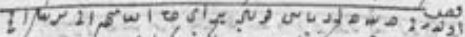

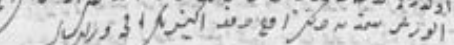
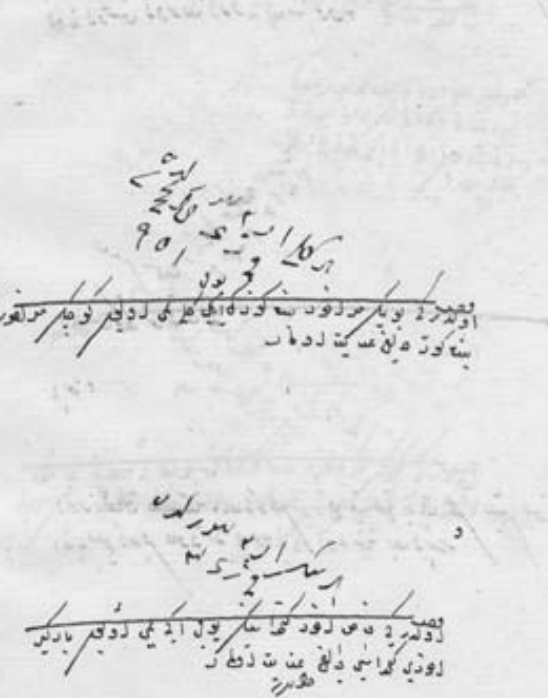
ŞEHZADE SELİM'İN KAZAYÂ DEFTERİ

27

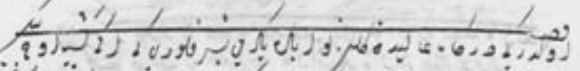

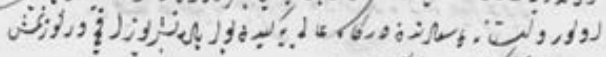

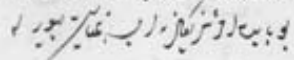
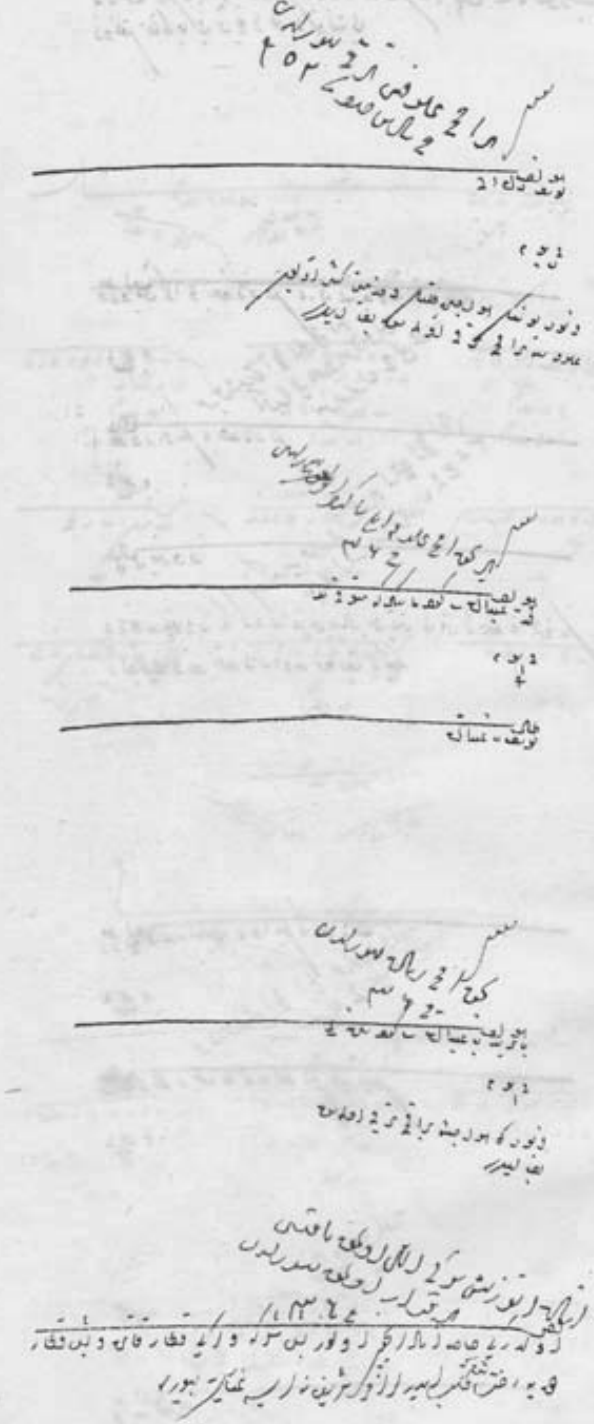
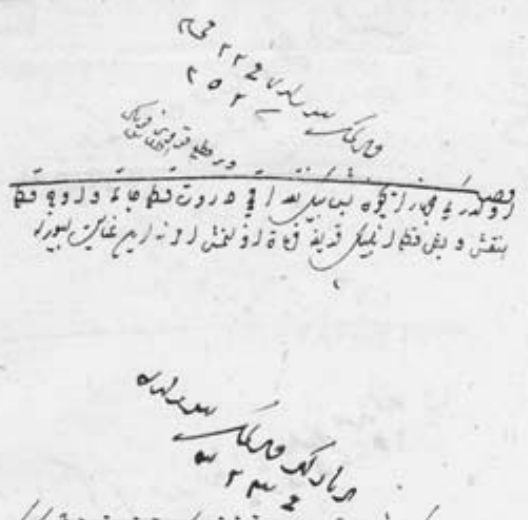

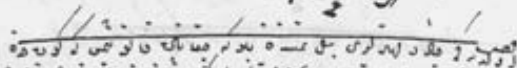

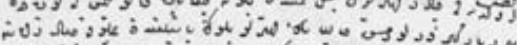

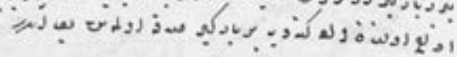
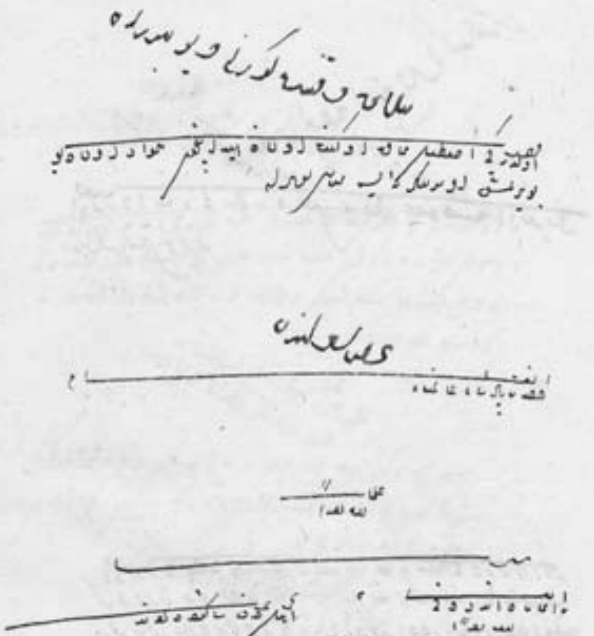

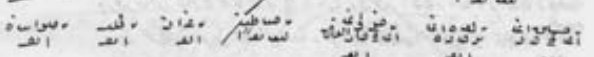
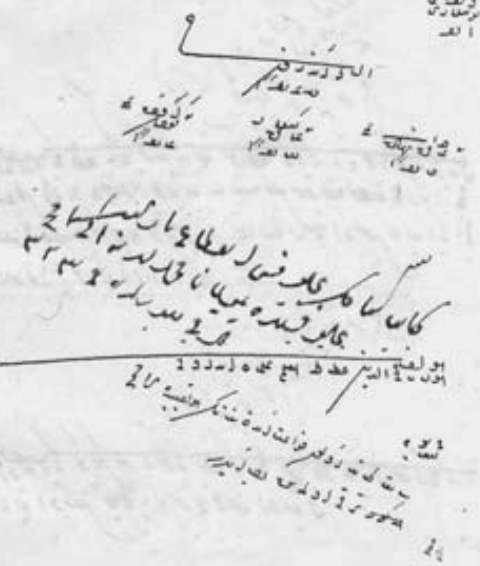
FERİDUN M. EMECEN

29
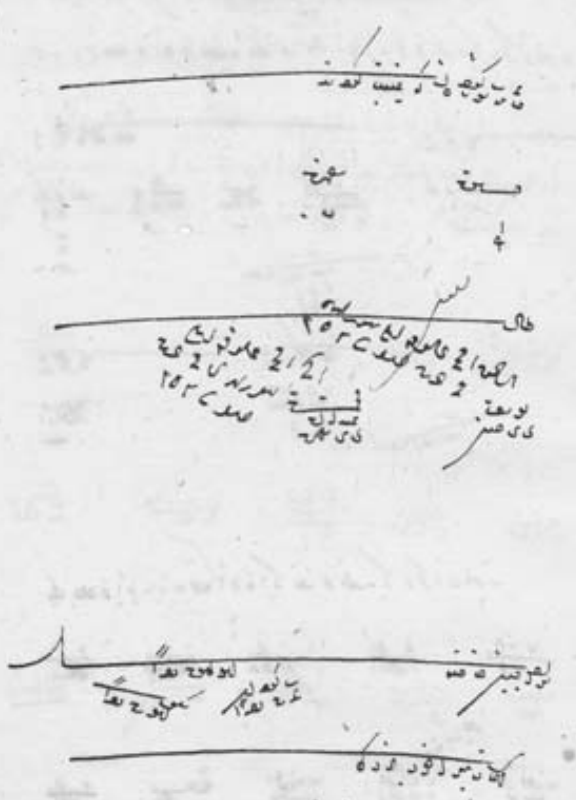

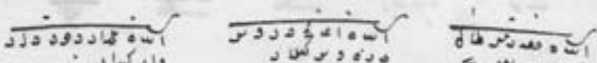

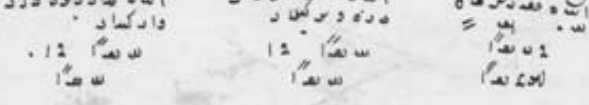

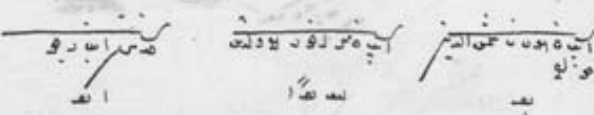

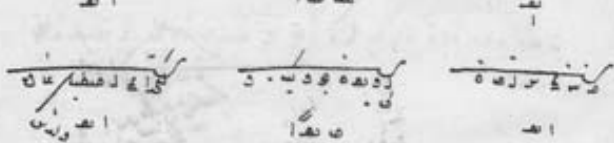

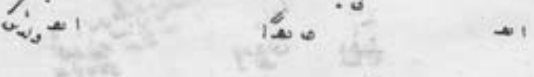

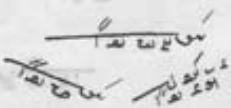
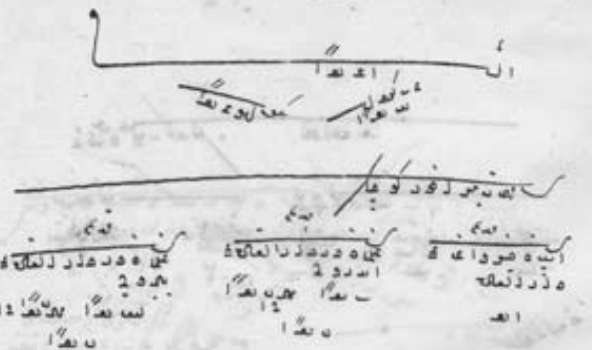

1 แ

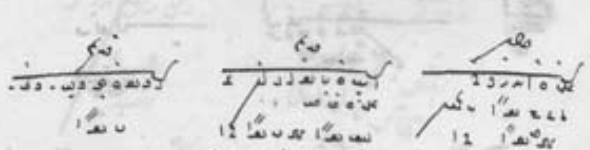

ijox

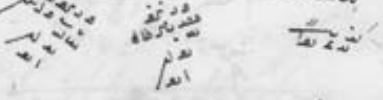

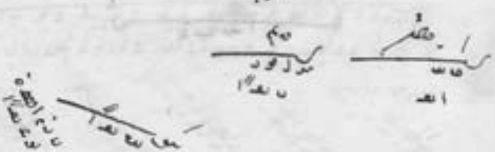

swis

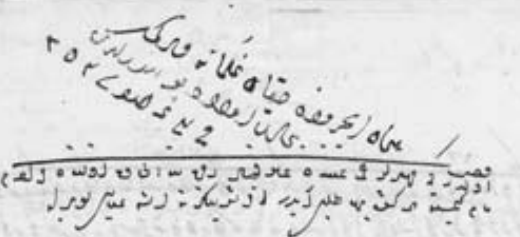

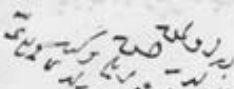

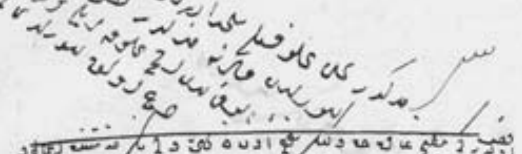

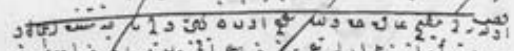

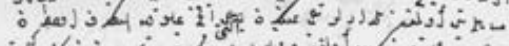

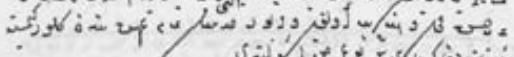

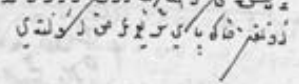

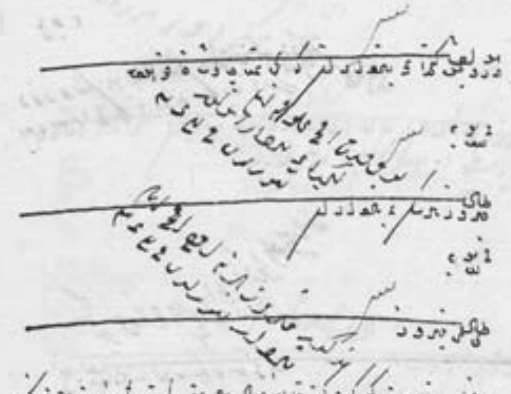

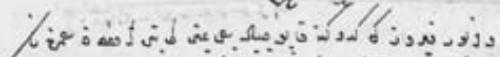

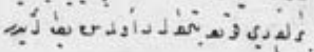
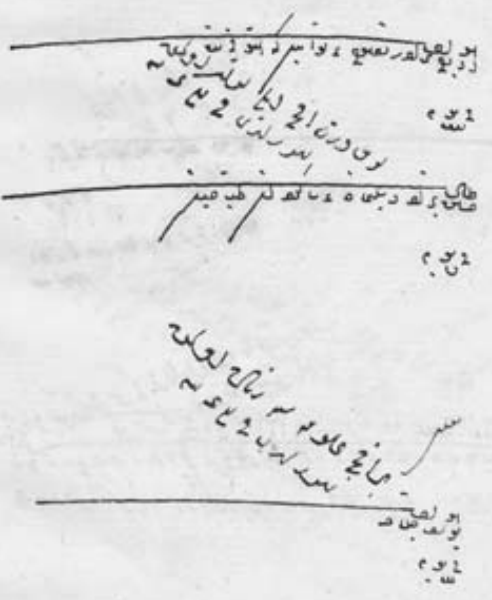

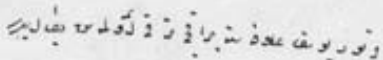


ŞEHZADE SELİM'İN KAZAYÂ DEFTERİ

31

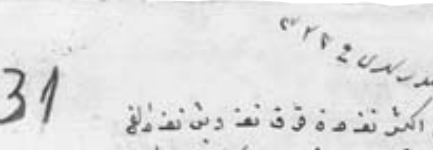

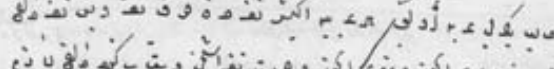

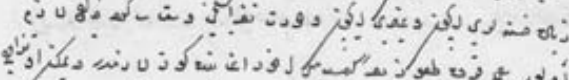

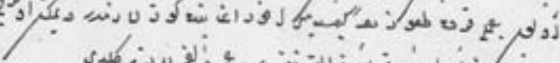

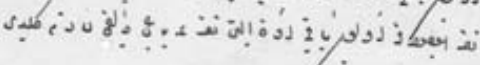

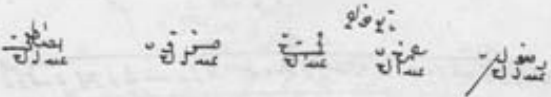

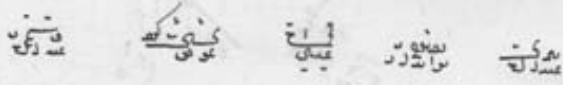

छा

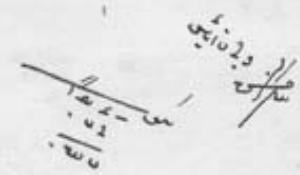

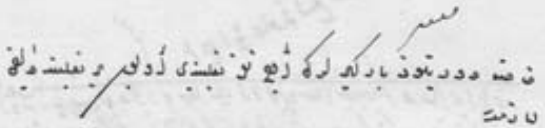

ivis

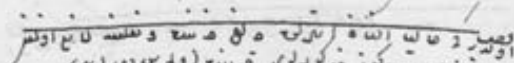

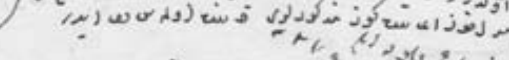

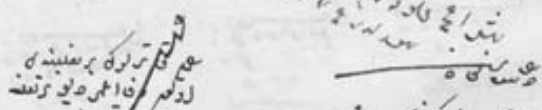

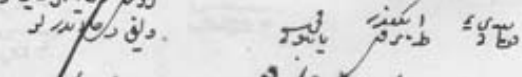

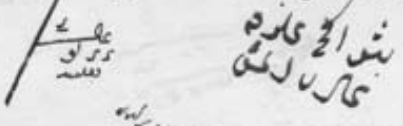

करा

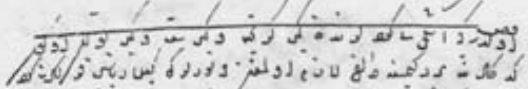

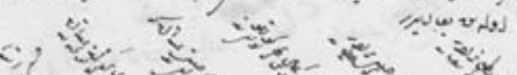

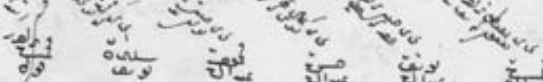

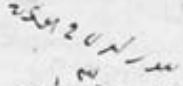

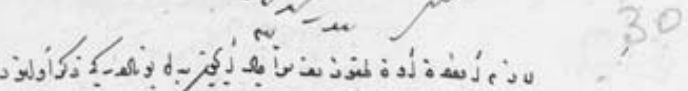

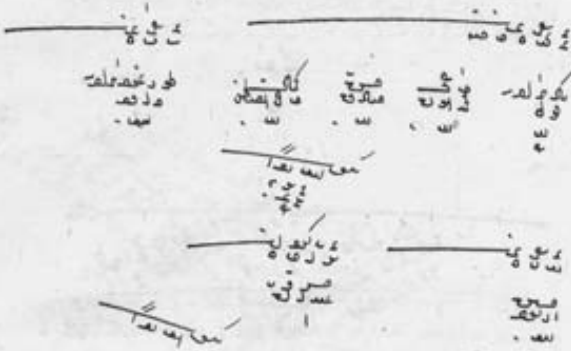

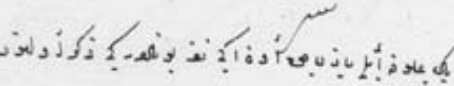

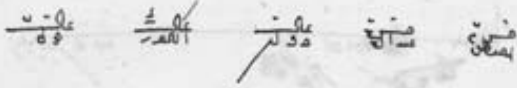

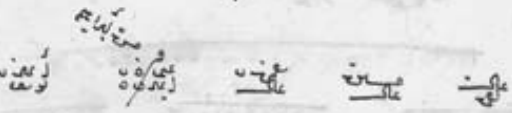

iscer

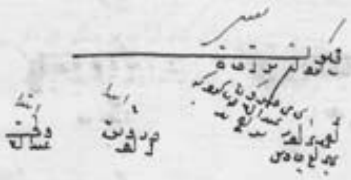

T1: vit
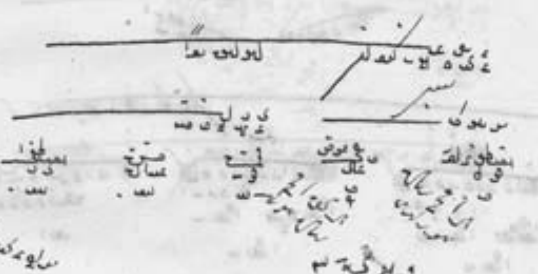

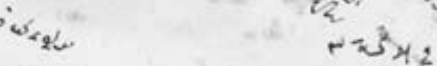

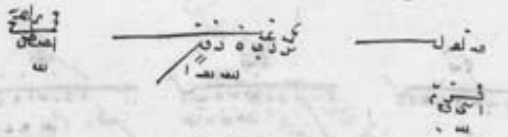

तो $\therefore \frac{2}{4}$

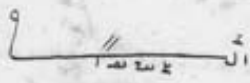


FERİDUN M. EMECEN

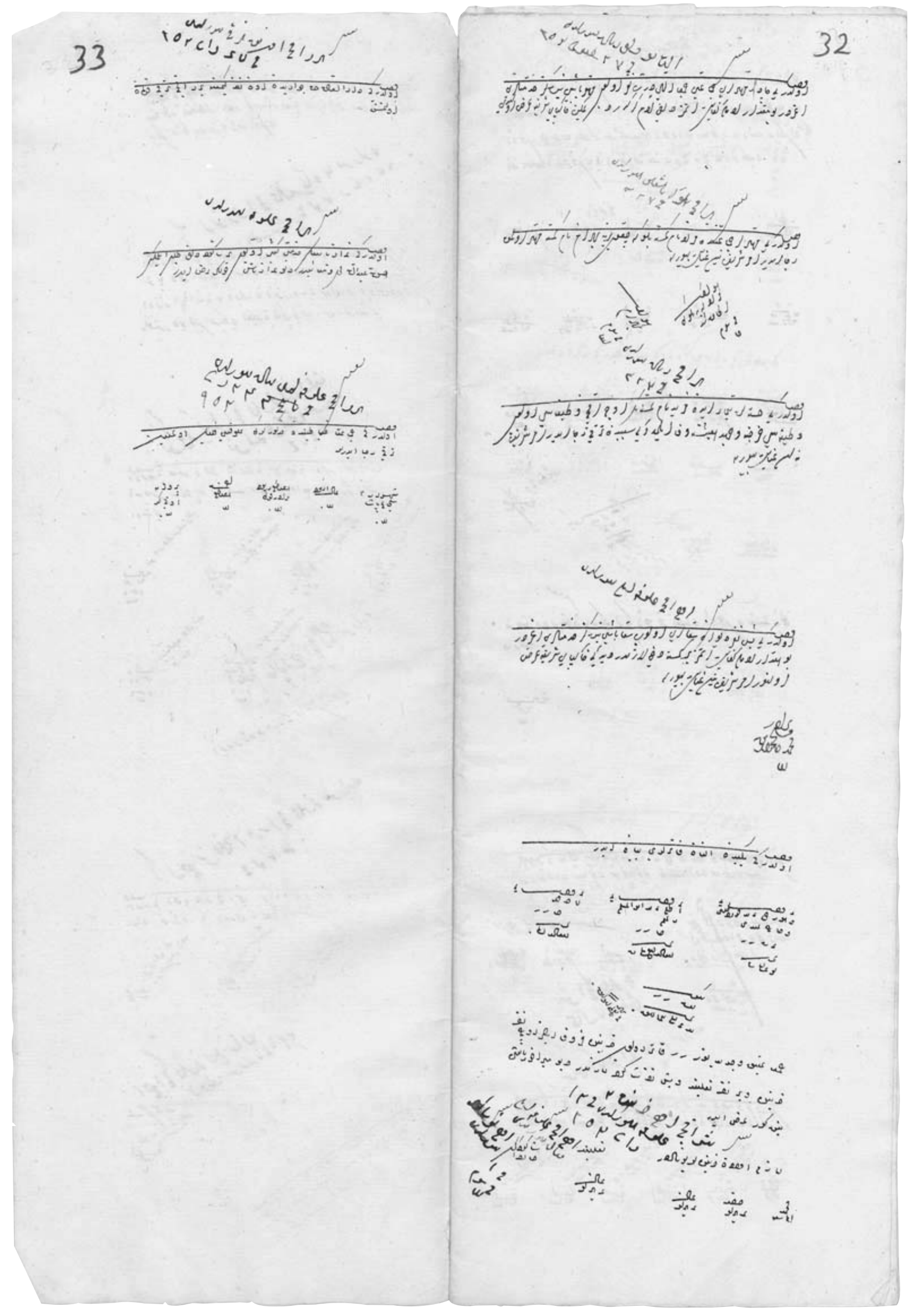


ŞEHZADE SELİM'İN KAZAYÂ DEFTERİ

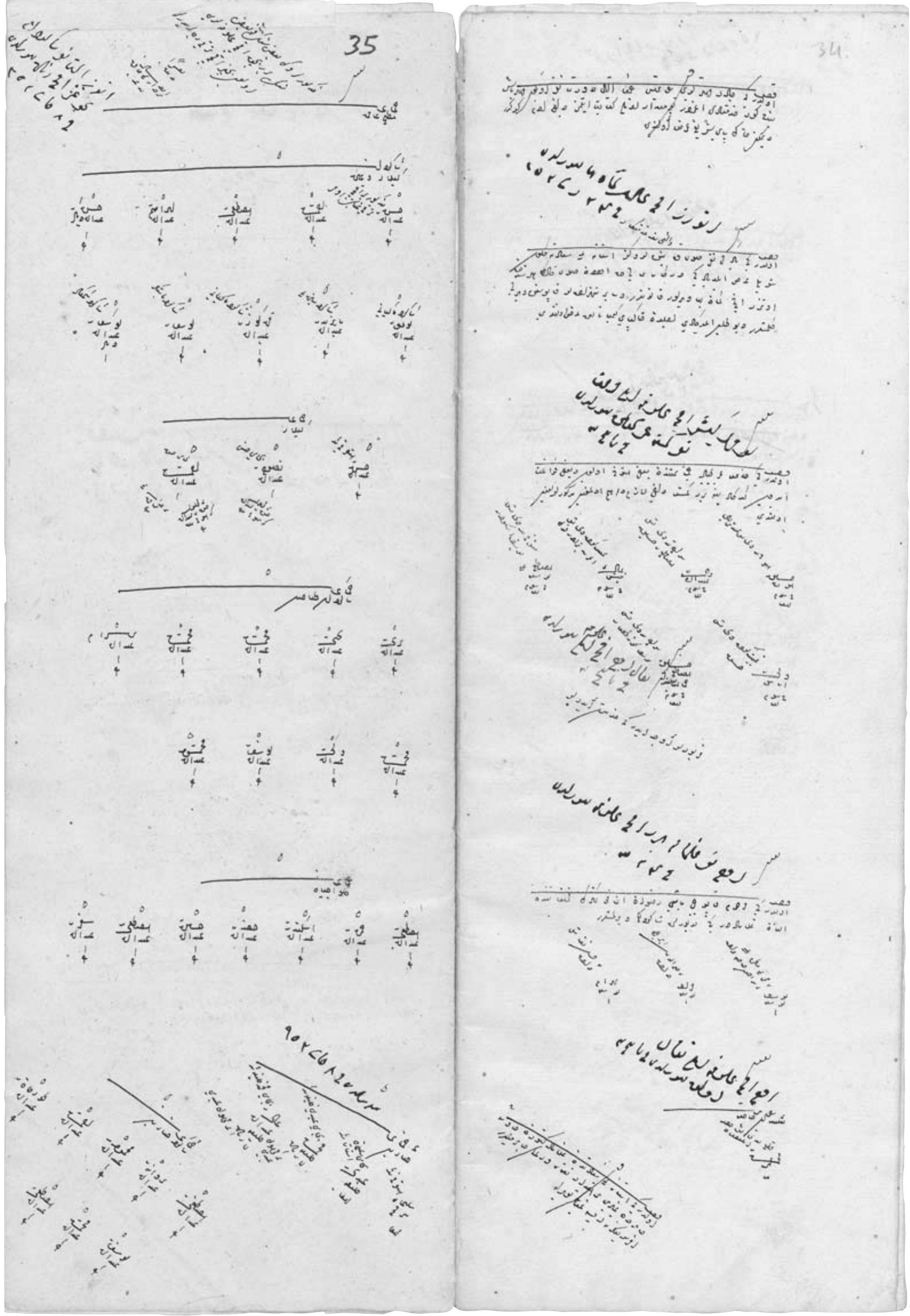


FERİDUN M. EMECEN

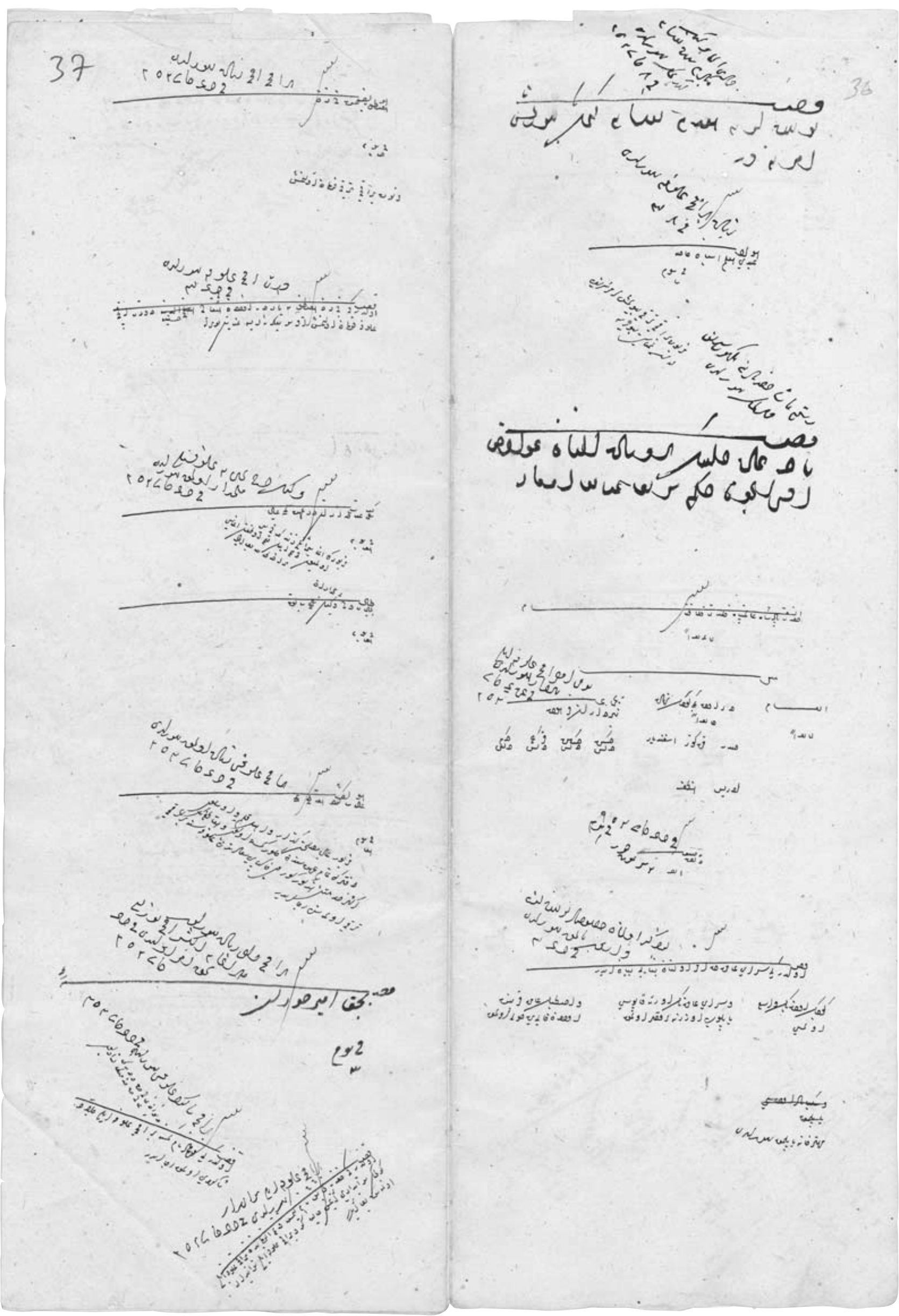


ŞEHZADE SELİM'İN KAZAYÂ DEFTERİ

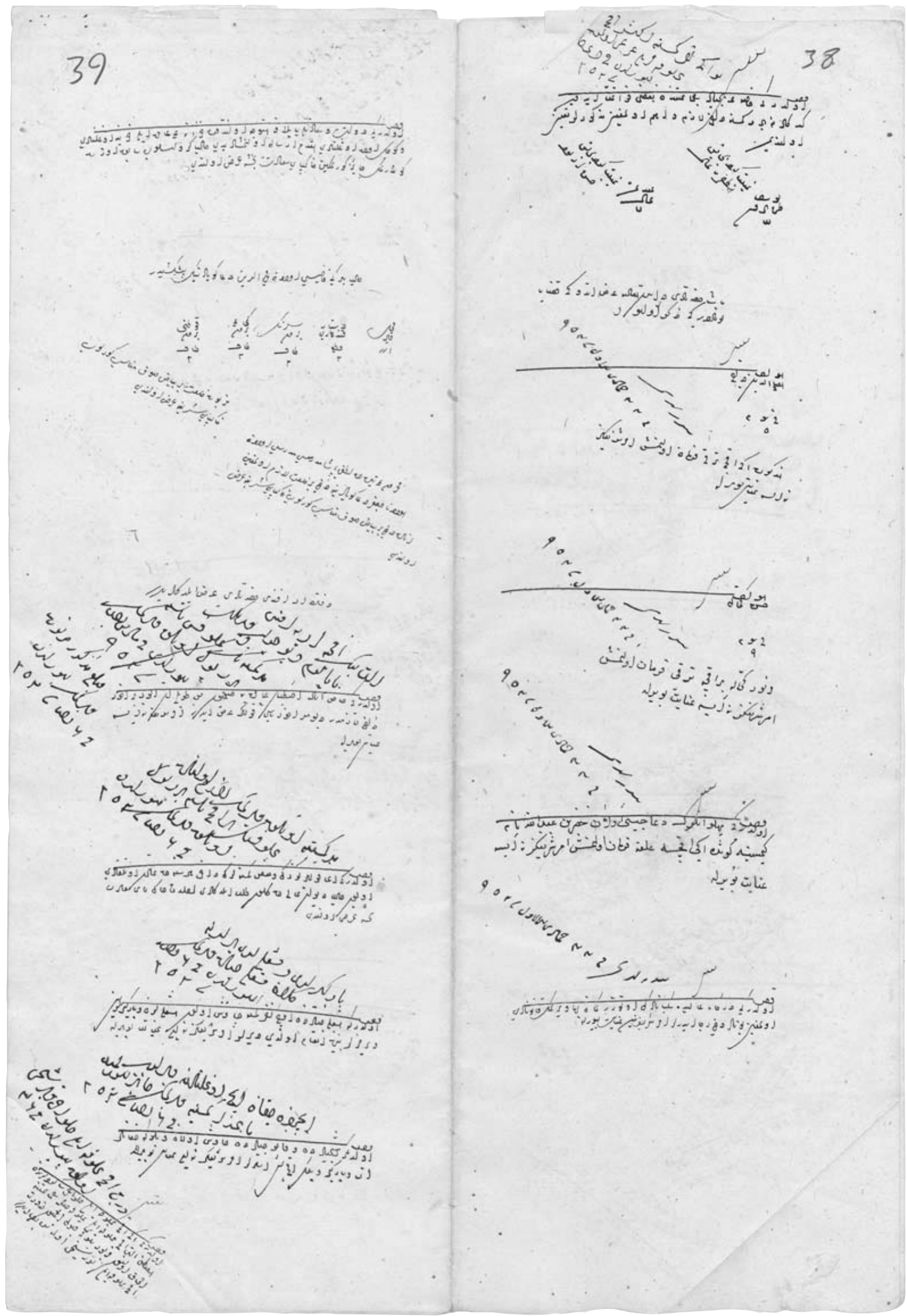




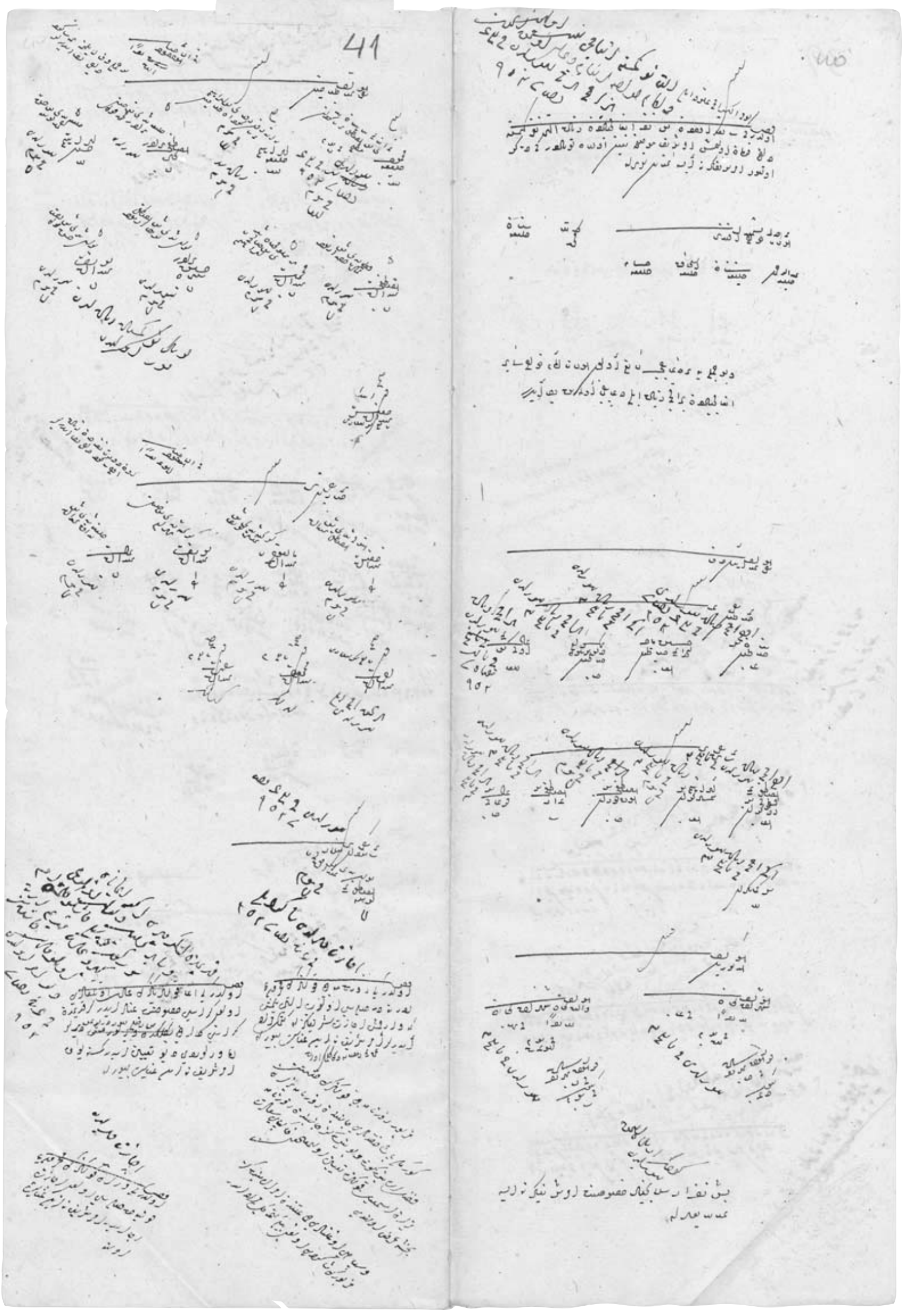


ŞEHZADE SELİM'İN KAZAYÂ DEFTERİ

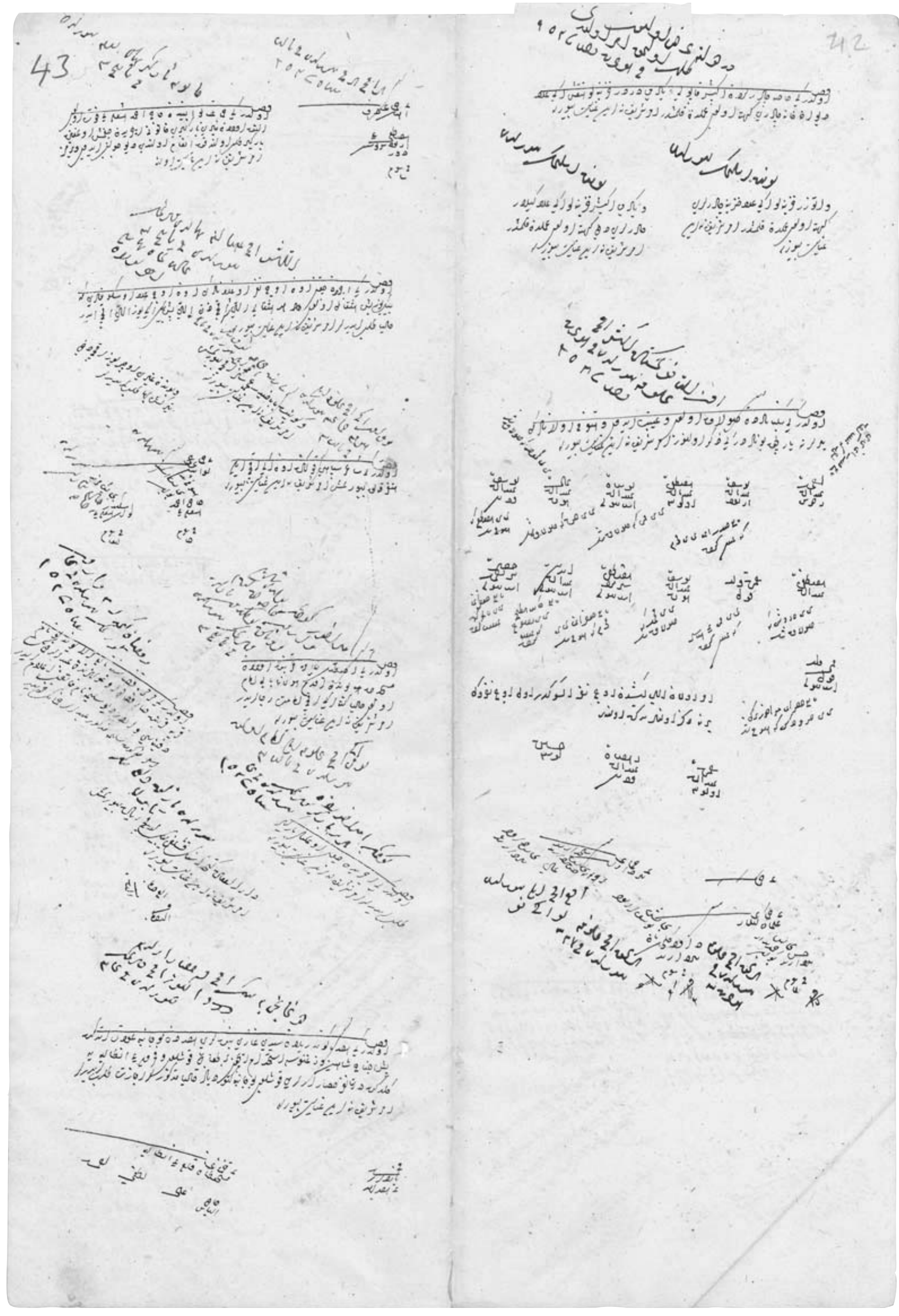




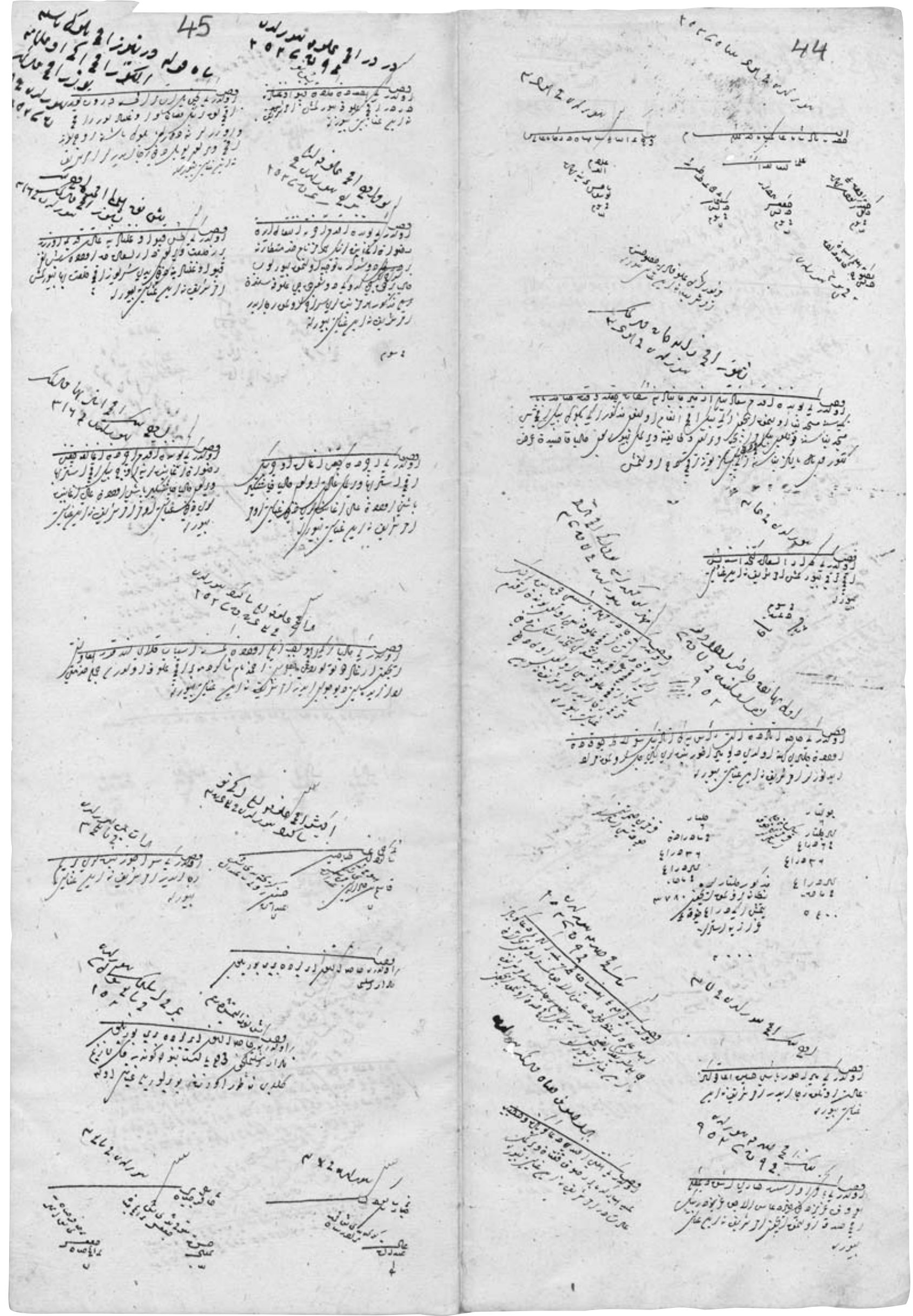


ŞEHZADE SELİM'İN KAZAYÂ DEFTERİ

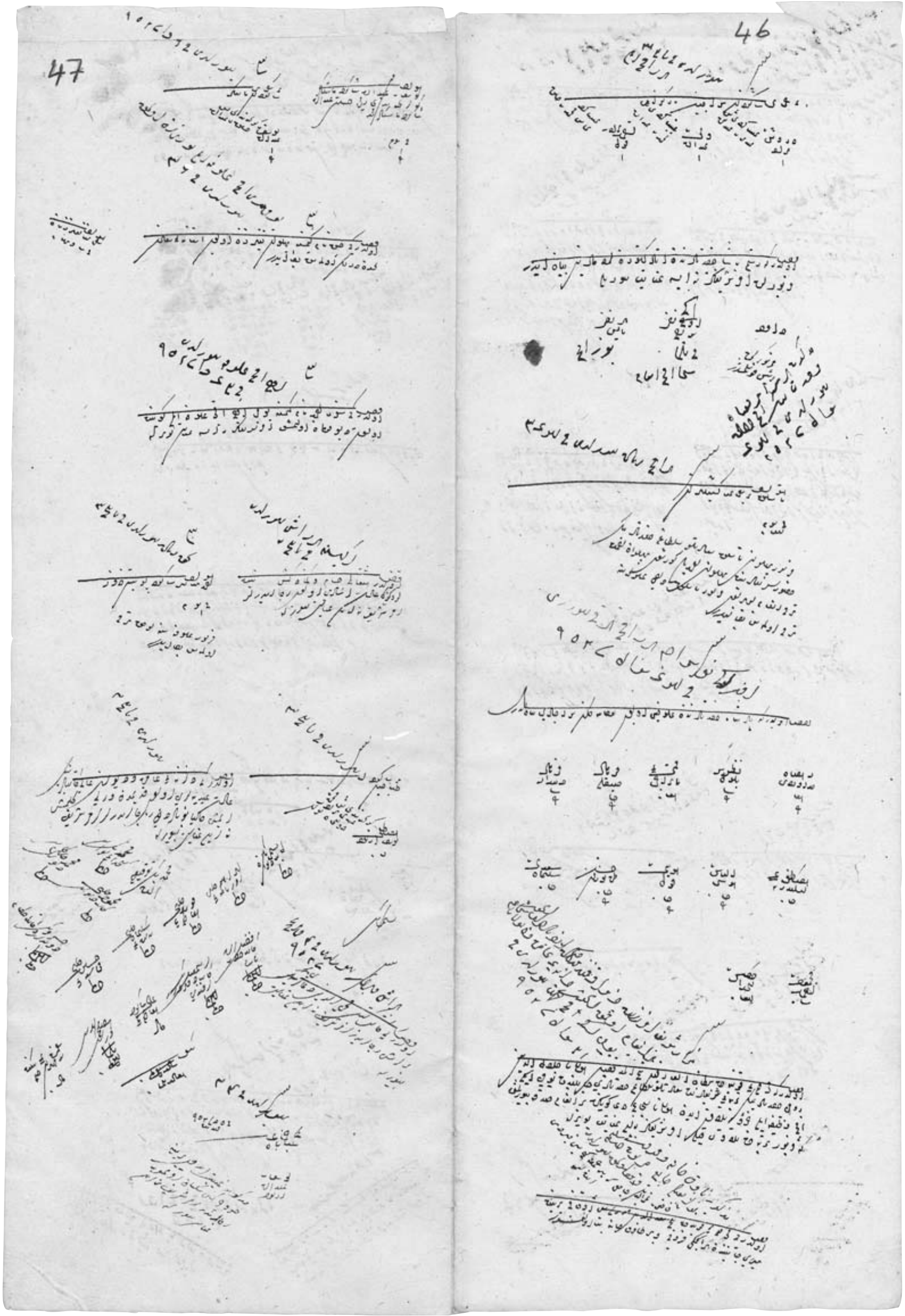


FERİDUN M. EMECEN

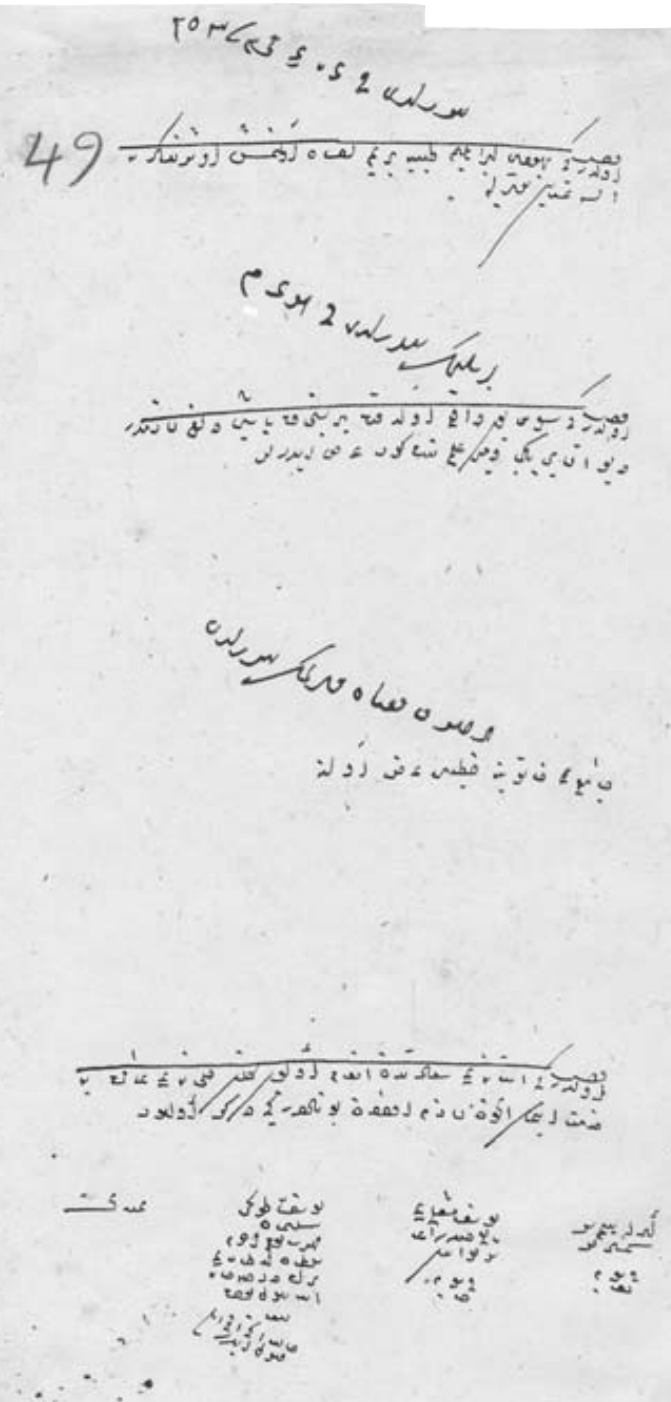

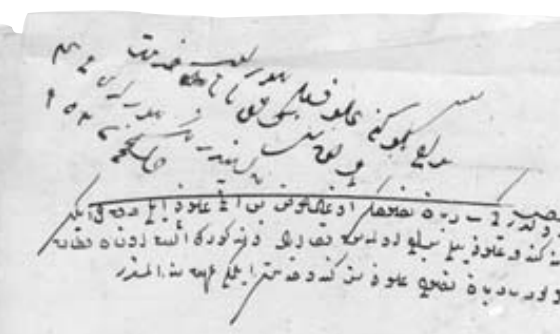
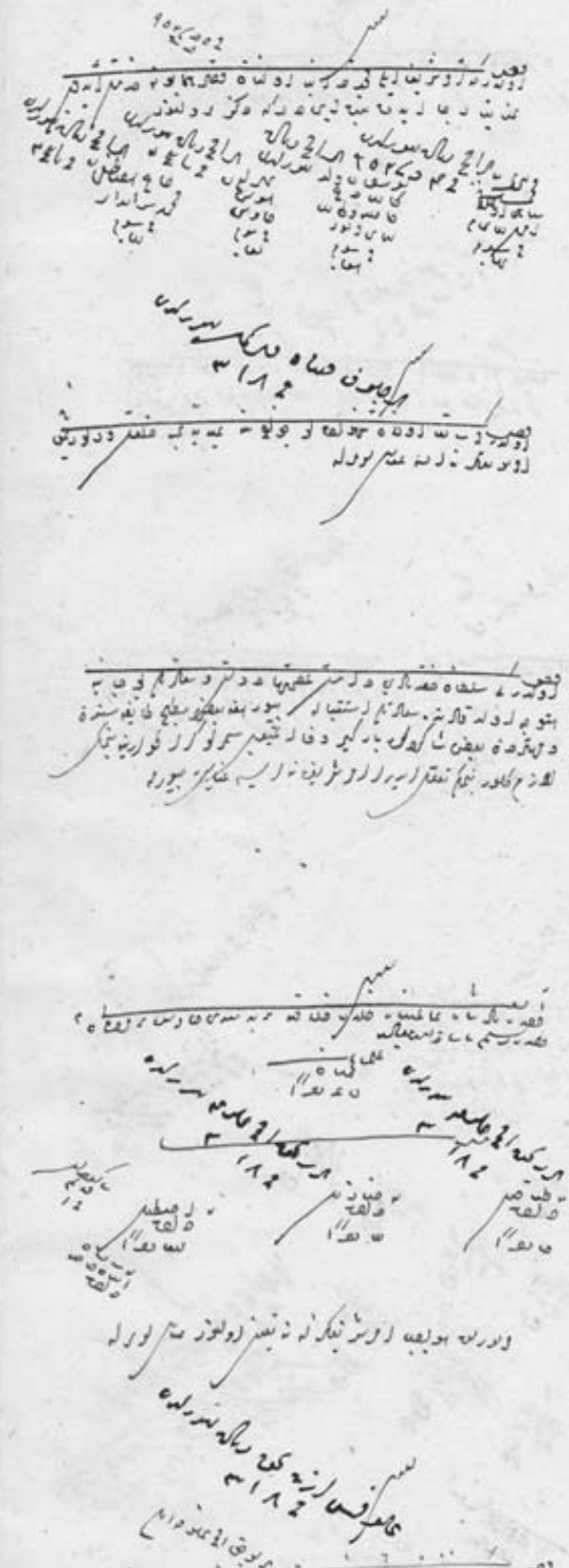

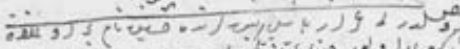

ic, d

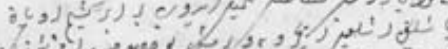

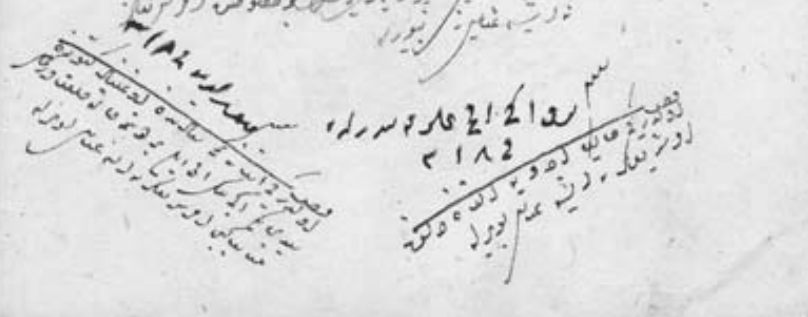

